UNIVERSIDADE DE SÃO PAULO

FACULDADE DE ECONOMIA, ADMINISTRAÇÃO E CONTABILIDADE DEPARTAMENTO DE CONTABILIDADE E ATUÁRIA PROGRAMA DE PÓS-GRADUAÇÃO EM CIÊNCIAS CONTÁBEIS

EVIDENCIAÇÃO DO CAPITAL INTELECTUAL

EM BANCOS ABERTOS NO BRASIL E NA ESPANHA

Carlos Eduardo Quinteiro

Orientador: Prof. Dr. Luiz Nelson Guedes de Carvalho

SÃO PAULO

2009 
Profa. Dra. Suely Vilela Sampaio Reitora da Universidade de São Paulo

Prof. Dr. Carlos Roberto Azzoni

Diretor da Faculdade de Economia, Administração e Contabilidade

Prof. Dr. Fábio Frezatti

Chefe do Departamento de Contabilidade e Atuária

Prof. Dr. Edgard Bruno Cornachione Junior

Coordenador do Programa de Pós-Graduação em Ciências Contábeis 
EVIDENCIAÇÃO DO CAPITAL INTELECTUAL

EM BANCOS ABERTOS NO BRASIL E NA ESPANHA

Dissertação apresentada ao Departamento de Contabilidade e Atuária da Faculdade de Economia, Administração e Contabilidade da Universidade de São Paulo como requisito para a obtenção do título de Mestre em Ciências Contábeis.

Orientador: Prof. Dr. Luiz Nelson Guedes de Carvalho

\section{SÃO PAULO}

2009 


\section{FICHA CATALOGRÁFICA}

Elaborada pela Seção de Processamento Técnico do SBD/FEA/USP

Quinteiro, Carlos Eduardo

Evidenciação do capital intelectual nos bancos abertos no Brasil e na Espanha / Carlos Eduardo Quinteiro. -- São Paulo, 2009.

$151 \mathrm{p}$.

Dissertação (Mestrado) - Universidade de São Paulo, 2009.

Bibliografia.

1. Bancos 2. Capital intelectual I. Universidade de São Paulo.

Faculdade de Economia, Administração e Contabilidade II. Título.

$\mathrm{CDD}-332.1$ 
A Deus pela ajuda espiritual 

É difícil escrever um texto que simbolize o agradecimento dispensado à elaboração da dissertação de mestrado visto a quantidade de pessoas que colaboraram, diretamente, indiretamente e até involuntariamente, para o seu desenvolvimento.

Agradeço, primeiramente, a minha mãe, que me deu a oportunidade única chamada de vida.

Reconheço, também, o esforço de todas as professoras e professores do ensino fundamental e médio pela gama de instruções e conhecimentos oferecidos.

Aos professores dos programas de graduação e pós-graduação do EAC-FEA-USP, igualmente, seguem os meus mais sinceros agradecimentos. Em especial, ao meu orientador, Professor L. Nelson Carvalho, por toda a ajuda, como também aos Professores Lázaro Plácido Lisboa e Maria Thereza Pompa Antunes, membros de minha banca de qualificação, que acreditaram no desenvolvimento desta dissertação, além de sempre me receberem e acolherem, contribuindo com suas valiosas sugestões de melhoria.

Aos colegas do curso de mestrado e doutorado por toda a parte acadêmica e humana compartilhadas.

À FIPECAFI pela ajuda financeira e apoio acadêmico - fatores determinantes para a realização deste trabalho.

A toda a sociedade que sempre financiou meus estudos, por meio de impostos, taxas e diversas contribuições.

Por último, à minha mãe, Eurides Francisca Quinteiro, pelo dom da vida e toda a educação que puder ter. 
“Perdão é o que busco ao acusar-me; Seja pois em meu favor essa verdade!" Dante Alighieri (A Divina Comédia - Canto XIV) 


\section{RESUMO}

O conhecimento é responsável, em grande parte, pelo desenvolvimento das pessoas que, reunidas em forma de sociedade, procuram o seu constante aprimoramento e evolução. Considera-se que a sociedade vive atualmente na denominada Era do Conhecimento e que uma das maiores aplicações do conhecimento é a sua utilização na forma de Capital Intelectual, um conjunto de Ativos Intangíveis à disposição das empresas e entidades. Os bancos constituem uma parte fundamental da economia e são considerados entre os principais agentes prestadores de serviços da sociedade moderna e, dessa forma, infere-se que fazem uso intensivo do Capital Intelectual. O presente estudo objetivou verificar, por meio de uma pesquisa qualitativa, como os bancos evidenciam o Capital Intelectual em suas demonstrações contábeis, relatórios de administração e demais relatórios financeiros. Para isso, escolheramse os bancos que cotizam na Bolsa de Valores de São Paulo e também os que cotizam na Bolsa Espanhola, a Bolsa de Madri. Conclui-se, por meio dos resultados obtidos, que os bancos atuantes no Brasil e na Espanha divulgam o Capital Intelectual principalmente nos relatórios de administração. Outra conclusão encontrada determinada pelo estudo é que a divisão Capital Estrutural foi a classificação que mais obteve ocorrências e, além disso, não há uma legislação ou orientação dos órgãos normatizadores de como devem ser evidenciados os itens pertencentes ao Capital Intelectual nas demonstrações. Todavia, não se pode afirmar, mediante a análise qualitativa, que os bancos na Espanha divulguem mais informações que os bancos no Brasil como poderia ser a expectativa de alguns. Por último, constata-se que houve um significativo aumento de informações divulgadas ao longo do tempo. 


\begin{abstract}
Knowledge is mostly responsible for development people, gathered together in Society, seek their constant improvement and welfare. It became usual to label the present times as the "Era of Knowledge" and one of the largest applications of knowledge is the Intellectual Capital, a set of intangible assets available to business entities. Banking organizations constitute a key part of the economic environment and are considered one of the main service suppliers of modern society, with intensive use of Intellectual Capital. This research aims to verify through a qualitative search how banks disclose Intellectual Capital in their financial statements, managerial and other reports. The entities object of this research were selected banking companies listed at São Paulo Stock Exchange and at the Madrid Stock Exchange. The results of this research permit to conclud that for the banks selected in this sample the disclosure of issues relating to intellectual capital were mainly found in Board of Directors' reports rather in any part of the financial statements or notes. The research also indicated that through this sort of qualitative analysis does not permit to conclude that Intellectual Capital disclosures in Spain woud contain more information than in Brazil, as it was thought at the beginning of this work. Furthermore, the Structural Capital's division was the classification mostly found. Lastly, although it has been noticed a significant increase of information disseminated over the years, there still is no guidance or requirements clear enough, developed by pertinent agencies or standard-setters, about the way Intellectual Capital items should be disclosed in the reports.
\end{abstract}





\section{SUMÁRIO}

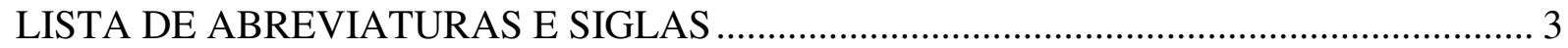

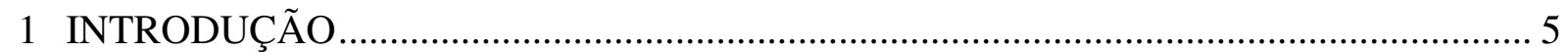

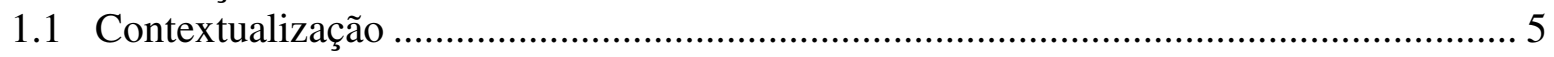

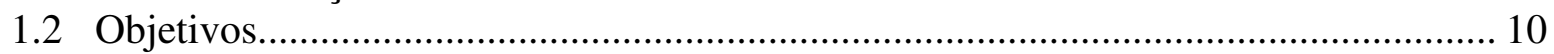

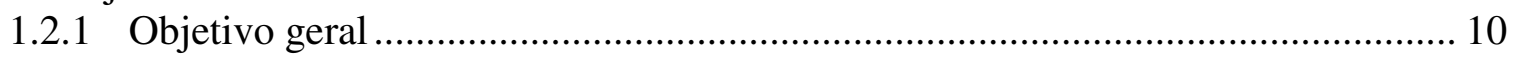

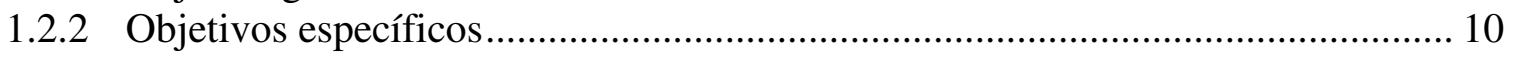

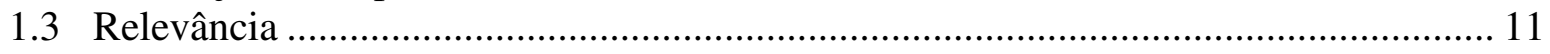

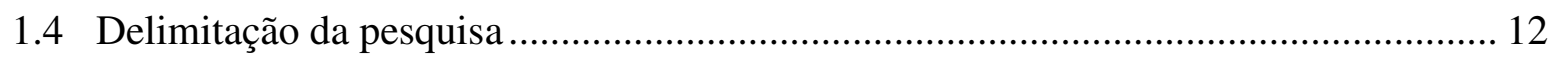

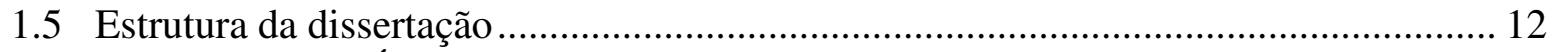

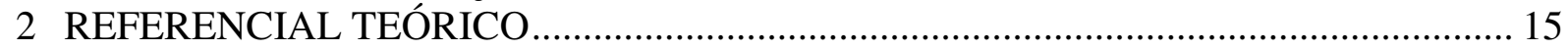

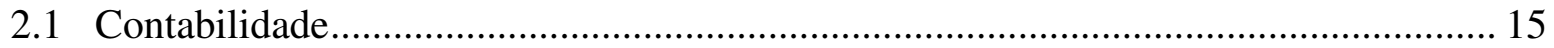

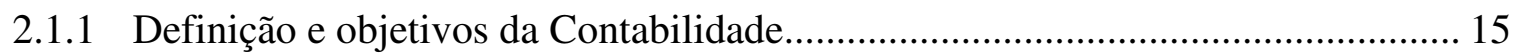

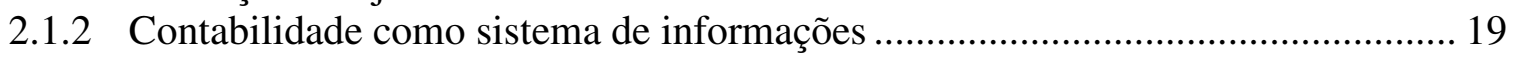

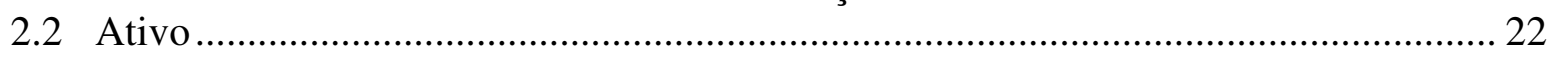

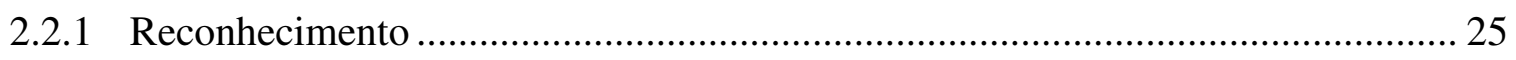

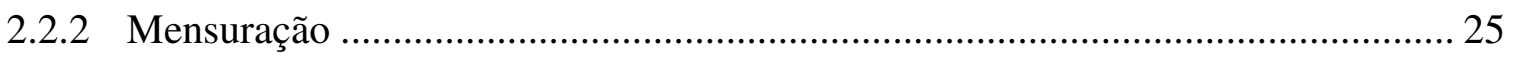

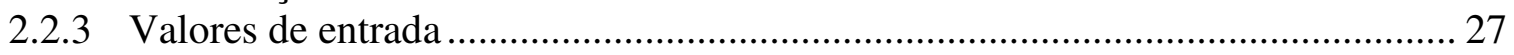

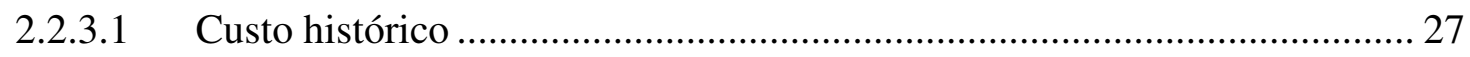

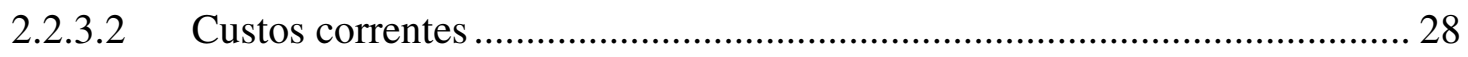

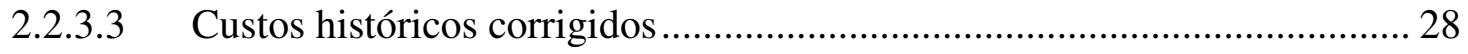

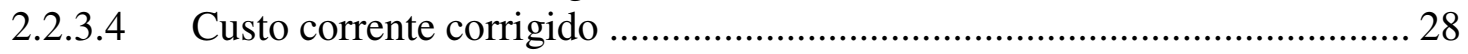

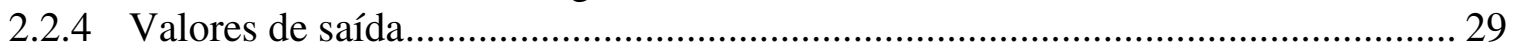

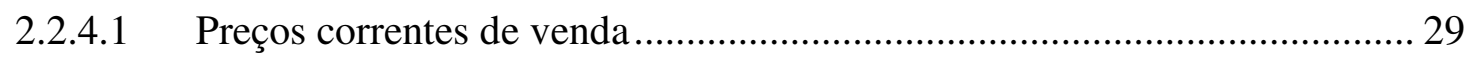

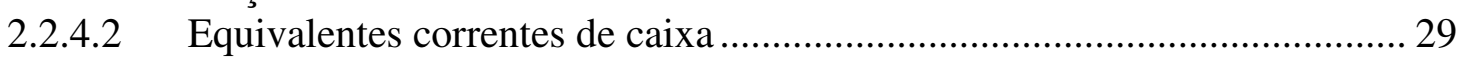

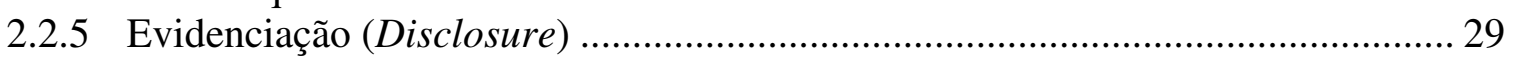

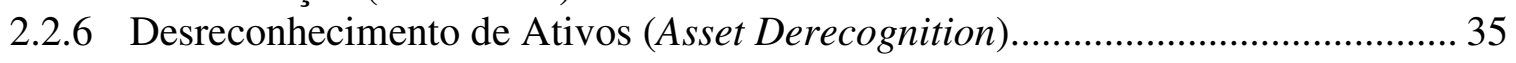

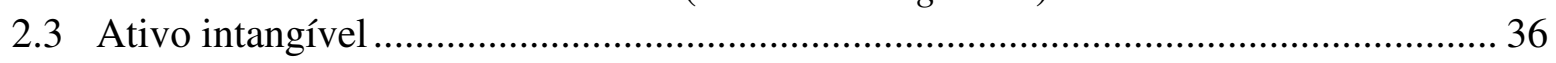

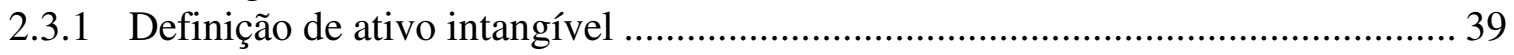

2.3.2 Reconhecimento e mensuração do ativo intangível .......................................... 41

2.3.3 Alterações no reconhecimento do ativo intangível no Brasil pelo CPC 04 -

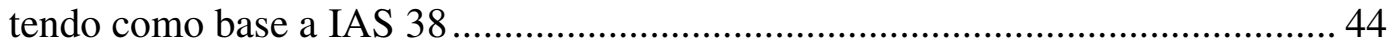

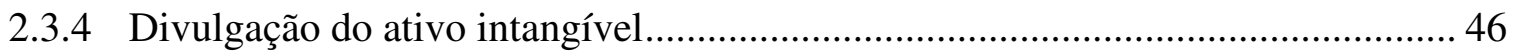

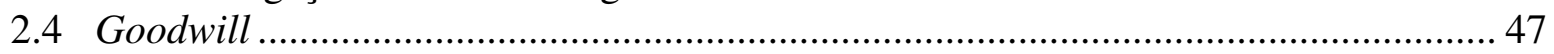

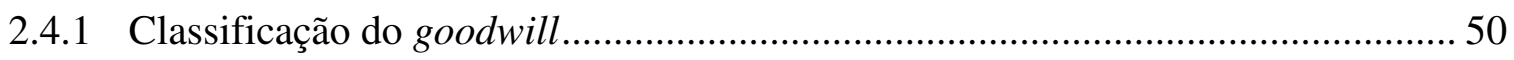

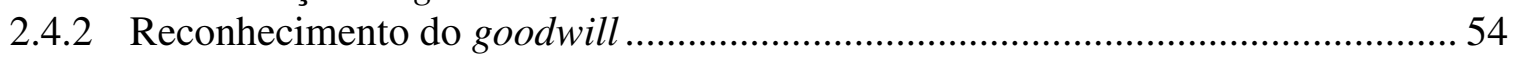

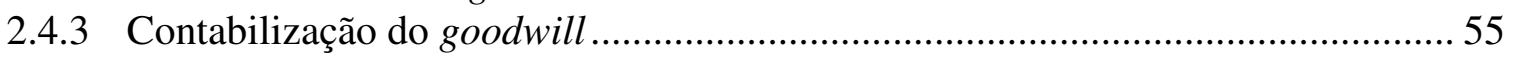

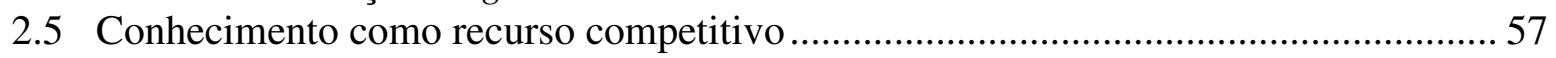

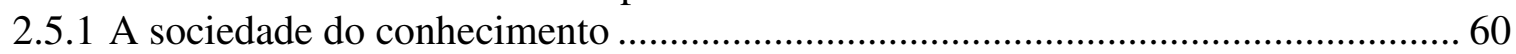

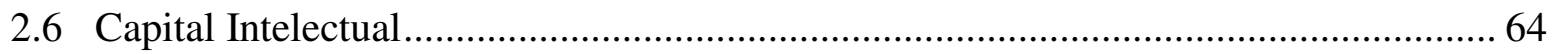

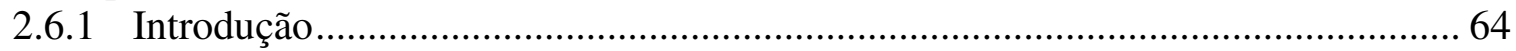

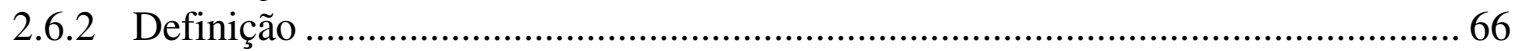

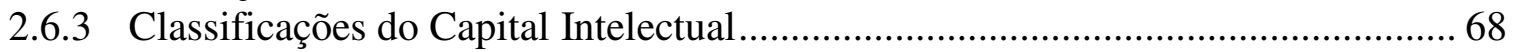

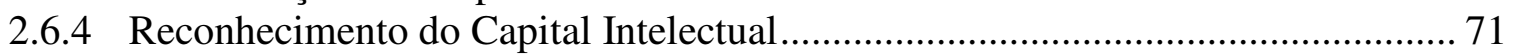

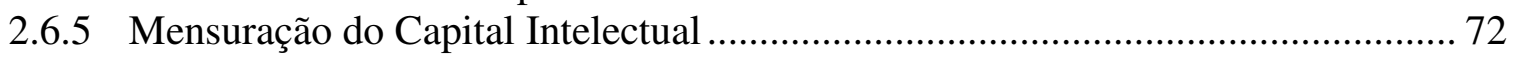

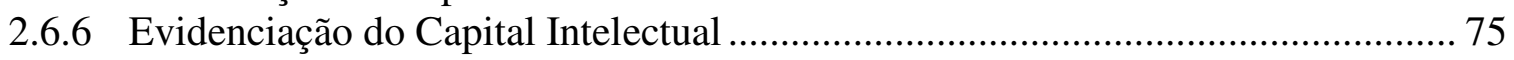

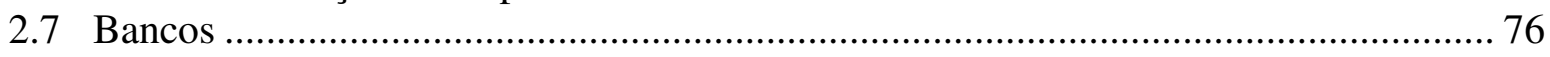




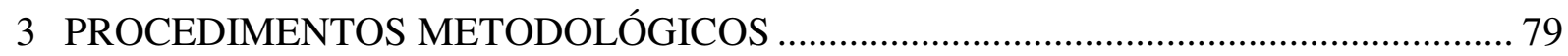

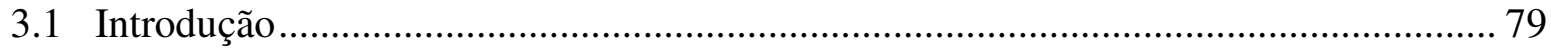

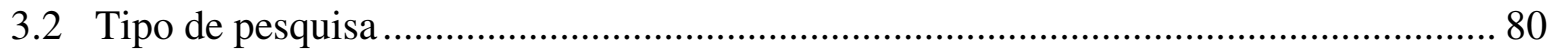

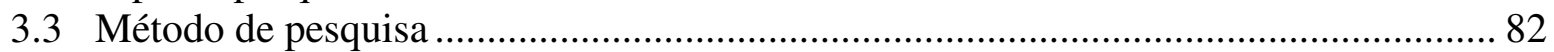

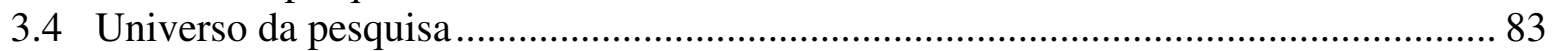

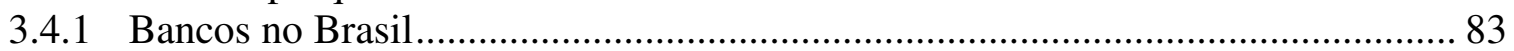

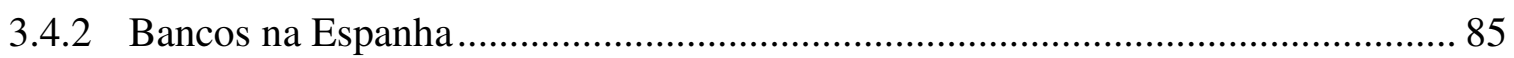

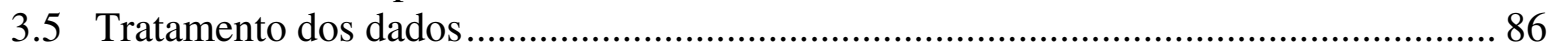

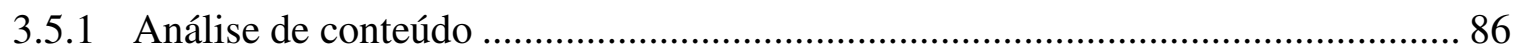

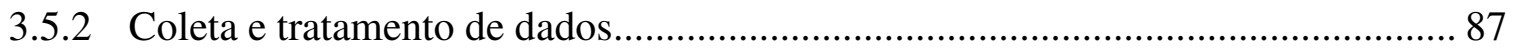

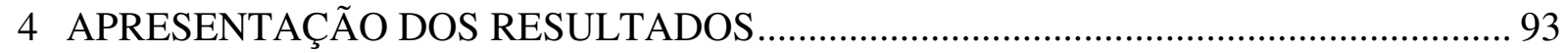

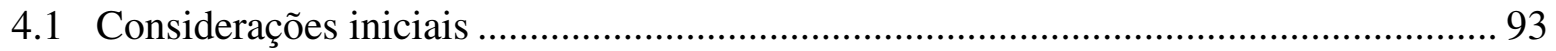

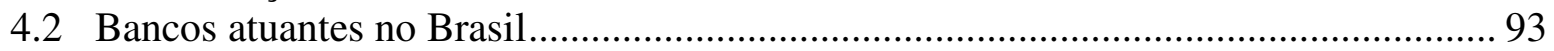

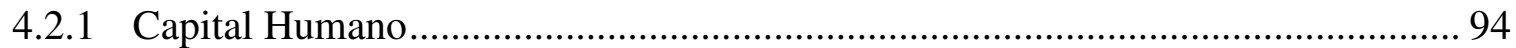

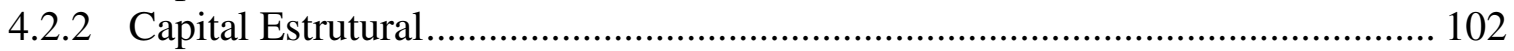

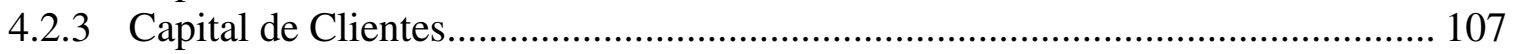

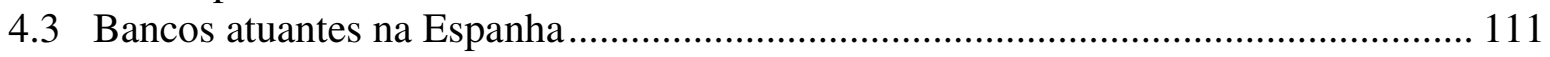

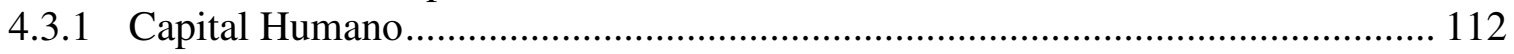

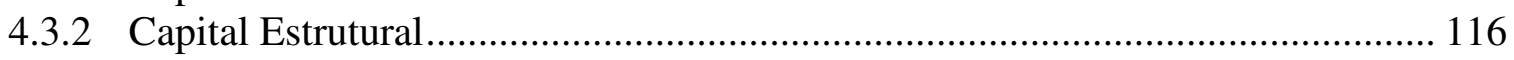

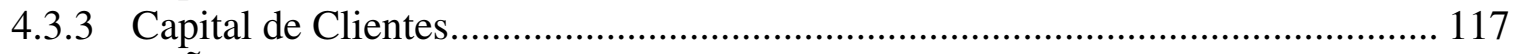

5 CONCLUSÃO

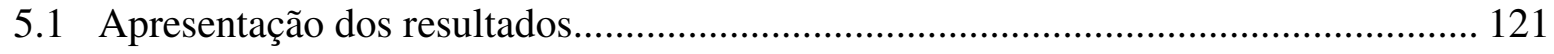

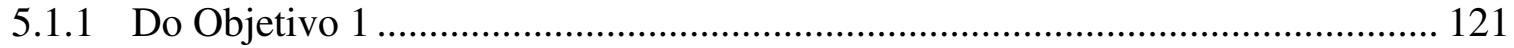

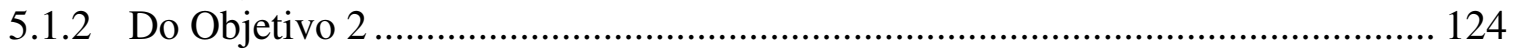

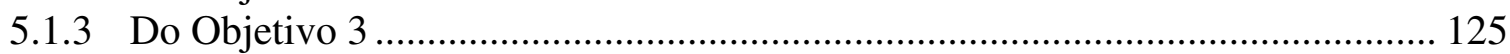

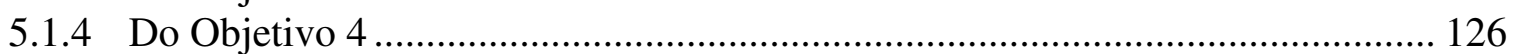

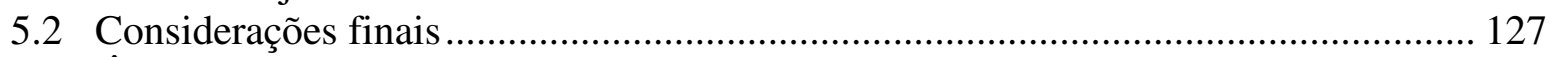

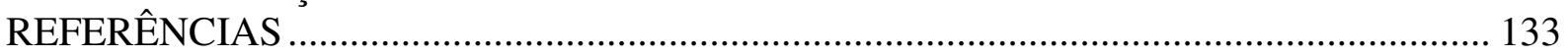

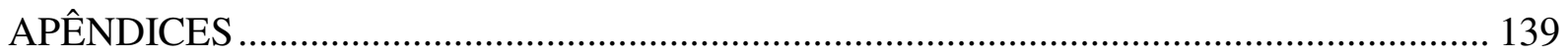




\section{LISTA DE ABREVIATURAS E SIGLAS}

1S08: Primeiro semestre de 2008

AA1000: Accountability 1000

AAA: American Accounting Association

AICPA: American Institute of Certified Public Accountants

ATM: Automatic Teller Machine

BANESPA: Banco do Estado de São Paulo

BB: Banco do Brasil

BBVA: Banco Bilbao Vizcaya Argentaria

BEP: Banco do Estado do Piauí

BESC: Banco do Estado de Santa Catarina

BM\&FBOVESPA: Bolsa de Mercadorias \& Futuros e Bolsa de Valores de São Paulo

BSC: Balanced Scorecard

BSCH: Banco Santander Central Hispano

CC: Capital de Clientes

CE: Capital Estrutural

CFC: Conselho Federal de Contabilidade

$\mathrm{CH}$ : Capital Humano

CI: Capital Intelectual

CNMV: Comisión Nacional del Mercado de Valores

CPC: Comitê de Pronunciamentos Contábeis

CVM: Comissão de Valores Mobiliários

DivExt: Divulgação Externa - software disponibilizado pela BM\&FBOVESPA

DJSI: Índice de Sustentabilidade da Bolsa norte-americana Dow Jones

DVA: Demonstração do Valor Adicionado

FASB: Financial Accounting Standards Board

FIPECAFI: Fundação Instituto de Pesquisas Contábeis Atuariais e Financeiras

GRI: Global Reporting Initiative

IBRACON: Instituto dos Auditores Independentes do Brasil

IAS: International Accounting Standard

IASB: International Accounting Standards Board

MAI: Monitor de Ativos Intangíveis

MBA: Master Business Administration

MVA: Market Value Added

NIC: Norma Internacional de Contabilidade

PAB: Posto de Atendimento Bancário

RA: Relatório de Administração

SIC: Sistema de Informação Contábil

SIG: Sistema de Informação Gerencial

TI: Tecnologia da Informação

VC: Valor Contábil

VM: Valor de Mercado

VMA: Valor de Mercado das Ações ou capital próprio

VMD: Valor de Mercado das Obrigações

VRA: Valor de Reposição dos Ativos 



\section{INTRODUÇÃO}

\subsection{Contextualização}

O conhecimento é responsável, em grande parte, pelo desenvolvimento das pessoas que, reunidas em forma de sociedade, procuram o seu constante aprimoramento e evolução. É sabido que o conhecimento se expande em diversas vertentes e que a Ciência foi uma das formas encontradas pelo homem para essa evolução.

Oliveira et al. (2003, p. 39) define Ciência como "a busca do conhecimento sistemático dos fenômenos de natureza e abrange um conjunto de conhecimentos racionais - certos ou prováveis - com a característica adicional de fazerem referência a objetos de uma mesma natureza."

O CFC, Conselho Federal de Contabilidade, por meio da Resolução n. 774/94, Apêndice que trata dos Princípios Fundamentais da Contabilidade, classifica a Contabilidade como Ciência Social, mencionando que sua definição é alicerçada em plena fundamentação epistemológica. O órgão, também, informa que, por consequência da acepção como Ciência Social, todas as demais classificações - método, conjunto de procedimentos, técnica, sistema, arte, para citar as mais correntes - referem-se a simples facetas ou aspectos da Contabilidade, usualmente concernentes à sua aplicação prática na solução de questões concretas as quais é submetida.

Iudícibus (2006) não classifica a Contabilidade como Ciência e sim como "um método apropriado de identificação, mensuração e comunicação de informações econômicofinanceiras que auxiliam o processo de tomada de decisão por parte dos gestores."

A despeito da visão contrária de Iudícibus (2006), a Contabilidade será tratada como Ciência e não como um método na presente dissertação. Será considerada a definição do CFC, na visão de que a Contabilidade se constitui num tipo de conhecimento sistematizado, ou seja, há formas específicas para o desenvolvimento de seus estudos e pesquisas dentro de sua linha de atuação. (OLIVEIRA et al., 2003, p. 48). 
Além disso, a Contabilidade, também, pode ser considerada como uma forma de conhecimento racional, sustentável e capaz de explicar e prever fenômenos em seu campo de estudo e assistir o processo de tomada de decisão. (Ibid., p. 50).

Supõe-se que a Contabilidade auxiliou o aprimoramento e a evolução da sociedade ao longo do tempo, por meio de suas constantes contribuições ao campo do conhecimento. Sobre a origem da Contabilidade, Iudícibus (2006, p. 34) menciona que é possível localizar os primeiro exemplos completos de contabilização no terceiro milênio antes de Cristo, na civilização da Suméria e da Babilônia, no Egito e na China.

Apesar de vários estudos sobre a origem da Contabilidade, não há uma data ou época precisa para afirmar seu surgimento, todavia, a Contabilidade provavelmente acompanhou o homem ao longo de sua evolução, desde a Era pré-histórica em que, possivelmente, havia, de maneira não sistematizada, algum tipo de controle dos frutos e sementes colhidas, quantidade de pesca e caça até os momentos atuais.

Em relação à evolução humana, Crawford (1994) classifica como "Eras" as etapas vividas pela sociedade humana ao longo do tempo. A primeira é denominada Era Agrícola, sendo seguida pela Era Industrial até, por fim, chegar à Era do Conhecimento, na qual o predomínio da utilização do conhecimento e uso intenso da tecnologia constituem a maneira pela qual as transações comerciais e os negócios são conduzidos.

Drucker (1970) explanou em sua obra "Uma Era de Descontinuidade”, há quase 40 anos, que o conhecimento seria utilizado como um recurso diferenciado pelas entidades que o detivessem. A denominada Era do Conhecimento caracteriza-se, segundo esse autor, por considerar como o mais importante e valioso ativo o conhecimento adquirido ao longo do tempo para aquelas entidades que o possuem.

Verifica-se a constante utilização do conhecimento adquirido nas indústrias, organizações em geral, empresas prestadoras de serviços, entidades comerciais e instituições financeiras. Como forma de expor a evolução desse conhecimento e a maneira como algumas empresas, principalmente as abertas, investem e divulgam em seus relatórios de informações financeiras dados como, por exemplo, aqueles que se referem ao montante investido em cursos para seus 
colaboradores, valores de investimento em infraestrutura, tecnologia e, também, seu relacionamento com clientes, fornecedores, Governo, sociedade, meio-ambiente e outros.

O conhecimento desenvolvido e adquirido pelas entidades ao longo do tempo pode ser classificado em três categorias: Capital Humano, Capital Estrutural e Capital de Clientes. Essa categorização foi definida, primeiramente, por Edvinsson e Malone (1998) e, partindo-se da premissa de que as empresas utilizam e aplicam esses conhecimentos, pode-se inferir que as entidades fazem uso do Capital Intelectual em seu dia a dia.

É comum o fato de as organizações buscarem o constante aumento de seu patrimônio e seus resultados econômico-financeiros. Para que ocorra a aferição e acumulação de riqueza, as firmas fazem uso e utilização de recursos econômicos clássicos como o capital, a terra e a mão de obra.

Esses recursos, segundo Drucker (1970), não são mais os fatores determinantes para que as entidades atinjam a meta de aumentar seu patrimônio, pois o uso do conhecimento, atrelado à tecnologia, às comunicações e aos transportes em geral, possibilitou a globalização da economia mundial e, consequentemente, o aumento da riqueza.

O recurso do conhecimento passa a ser essencial na atualidade e essa assertiva pode ser confirmada por meio do exemplo de que as diversas máquinas, em geral, produzidas pelo conhecimento técnico e know-how das companhias, constantemente, substitui a força física humana na produção fabril, todavia o conhecimento não pode ser substituído. Outro exemplo são as atividades econômicas dos centros urbanos que, muitas vezes, têm como foco a prestação de serviços e esse tipo de serviço é baseado no conhecimento envolvido. (ANTUNES, 2000, p. 24).

Considerando-se a área de prestação de serviços como o centro da atividade econômica atual, cabe destacar o importante papel desempenhado pela figura das instituições financeiras, especialmente os bancos, nesse contexto. Uma das principais funções dos bancos é a intermediação financeira entre os agentes que possuem recursos em excesso e os agentes deficitários de recursos, os que necessitam de capital a fim de iniciar, aprimorar ou ampliar seus negócios, como, também, os consumidores finais que desejam ampliar sua base de consumo. (FORTUNA, 2002). 
Acredita-se que os bancos obtiveram, nas últimas décadas, um forte aliado à condução de seus negócios, ou seja, o advento do uso intensivo da tecnologia da informação e sua utilização em larga escala. Esse emprego auxiliou muito os bancos a aumentar seu ritmo e volume de negócios com o passar do tempo.

Infere-se que os bancos se assemelham a um emaranhado de sistemas interligados, em que os usuários finais (ou clientes) podem processar diretamente suas operações, sendo que a atividade principal dos bancos, nesse cenário, é garantir o funcionamento desse macro ambiente por meio de seu parque tecnológico, conhecimento adquirido e relacionamento com clientes, fornecedores e outros interessados.

A ênfase do relacionamento com os clientes dá-se em diversas vertentes: como mantê-los satisfeitos, não permitir que migrem para outro concorrente, oferta e comercialização de novos produtos e serviços entre outros. Dessa forma, o constante investimento em ativos intangíveis pode ser uma das maneiras de contribuir para o cumprimento das vertentes citadas, além do fato de que o uso da tecnologia da informação, atrelado ao emprego do conhecimento, constitui importante diferencial ao negócio bancário.

El-Bannany (2008) investigou as determinantes do Capital Intelectual nos bancos do Reino Unido, no período de 1999 a 2005, e constatou que os investimentos em tecnologia da informação, sistemas, treinamentos e outros itens ligados ao desenvolvimento dos colaboradores têm um impacto significativo no resultado desses bancos.

Confrontando-se as três classificações do Capital Intelectual dadas por Edvinsson e Malone (1998), Capital Humano, Capital Estrutural e Capital de Clientes, ante a estrutura do funcionamento dos negócios bancários citada anteriormente, pode-se deduzir que as instituições financeiras, assim como outras empresas, fazem uso do Capital Intelectual em suas operações.

Destaque-se que muitos autores associam o conceito de Capital Intelectual ao Ativo Intangível (BROOKING, 1996; EDVINSSON; MALONE, 1998; SVEIBY, 1997; LEV, 2001; ANTUNES, 2004). Assim, é necessário verificar se a literatura existente sobre o tema Ativo Intangível faz alusão, diretamente, ao Capital Intelectual ou se faz, indiretamente, 
utilizando o conceito de Goodwill. Além disso, cabe uma revisão bibliográfica sobre o Capital Intelectual visto a importância de sua utilização pelas empresas.

Os bancos constituem uma parte fundamental da economia e são considerados um dos principais agentes prestadores de serviços da sociedade moderna. Dessa forma, julga-se relevante o desenvolvimento de estudos que evidenciem a maneira e quais informações referentes ao Capital Intelectual são divulgadas mediante suas demonstrações financeiras.

Para elaboração deste estudo, optou-se por selecionar os bancos abertos brasileiros que cotizam em bolsa de valores com o intuito de obter o maior número de informações possíveis e, também, por sua fácil acessibilidade. No caso brasileiro, entende-se como banco aberto a instituição bancária que negocia suas ações em bolsa de valores, atualmente, BM\&FBOVESPA, fusão entre a Bolsa de Mercadorias \& Futuros e a Bolsa de Valores de São Paulo.

Além disso, elegeu-se, igualmente, selecionar instituições financeiras de outro país para que possam ser analisadas a fim de se obter uma comparação descritiva em relação aos bancos brasileiros diante da divulgação do Capital Intelectual. Isso posto, escolheu-se, por conveniência e facilidade na obtenção de informações, os bancos espanhóis que cotizam em bolsa, neste caso, na Bolsa de Madri.

Partindo das afirmações anteriores, a questão de pesquisa a ser respondida ao término desta dissertação é a seguinte:

Quais informações sobre o Capital Intelectual são evidenciadas nas instituições bancárias abertas no Brasil e na Espanha e como se referem no contexto da divulgação das demonstrações contábeis completas? 


\subsection{Objetivos}

\subsubsection{Objetivo geral}

O objetivo geral desta dissertação é conhecer como o Capital Intelectual é evidenciado e quais de suas informações são divulgadas nas demonstrações contábeis, notas explicativas e relatórios de administração dos bancos abertos no Brasil e na Espanha.

\subsubsection{Objetivos específicos}

Com o intuito de atingir o objetivo geral desta dissertação, é necessário que outros objetivos adicionais sejam elencados. Esses itens são conhecidos como objetivos específicos.

Os objetivos específicos a serem respondidos são os seguintes:

1. Verificar os conceitos de Capital Intelectual utilizados pelos bancos cotizantes no Brasil e na Espanha em suas demonstrações financeiras.

2. Conhecer o nível de evidenciação (disclosure) do Capital Intelectual nos bancos cotizantes no Brasil e dos bancos cotizantes na Espanha.

3. Conhecer os itens do Capital Intelectual que são divulgados de maneira voluntária ou não pelos bancos.

4. Verificar se a evidenciação do Capital Intelectual nas instituições financeiras cotizantes nos dois países está se alterando ao longo do tempo. 


\subsection{Relevância}

Iudícibus, Martins e Gelbcke (2007, p. 29) asseveram que a Contabilidade é, objetivamente, um sistema de informação e avaliação destinado a prover seus usuários com demonstrações e análises de natureza econômica, financeira, física e de produtividade, com relação à entidade objeto de contabilização.

A Contabilidade possui grande importância como fonte de informação aos tomadores de decisão e demais usuários, tendo como base para a divulgação de dados as demonstrações contábeis. Lopes e Martins (2005, p. 76) corroboram essa assertiva, afirmando que "a Contabilidade possui papel central como fonte de informações no mercado financeiro."

Além disso, a informação contábil possui forte impacto nos preços das ações que são cotizadas em bolsa, pois a tempestividade e o poder de relevar novos fatos à tomada de decisão faz com que os especialistas se norteiem pelos indicativos que a Contabilidade oferece. (BARTH; CLINCH; SHIBANO, 2001).

Para que a Contabilidade seja capaz de auxiliar no processo informacional, é necessário que ela guarde estreita relação entre a realidade econômica da entidade e a do meio em que ela está inserida. Se a informação contábil não estiver intimamente relacionada com a realidade subjacente, ela perderá utilidade para os agentes tomadores de decisão. Conclui-se, dessa forma, que, se o Capital Intelectual possui valor econômico, a sua não evidenciação em momento oportuno acarretará em não atender aos objetivos propostos da Contabilidade.

As instituições bancárias utilizam itens que caracterizam o Capital Intelectual em suas operações e, além disso, não há muitos estudos que abordam a relação entre bancos e o Capital Intelectual. Dessa maneira, cabe a realização de pesquisa que possa abranger esses

dois temas. Assim, o presente estudo tem por finalidade mostrar a forma e quais itens do Capital Intelectual são divulgados pelas instituições financeiras, especificamente os bancos, que atuam no Brasil e na Espanha. 


\subsection{Delimitação da pesquisa}

A seguir é detalhada a forma de delimitação desta dissertação, visto que há necessidade de impor algumas demarcações para que não exista influência significativa de subjetividade no estudo, dado que a pesquisa qualitativa, muitas vezes, possui características oriundas de interpretação do autor.

Silva (2003, p. 50), assim, explica delimitação do tema: “[...] Delimitar significa pôr limites, isto é, determinar a profundidade, abrangência e extensão do assunto. Devem-se escolher temas menos abrangentes e que possam ser esgotados pela pesquisa."

A pesquisa centrou seus estudos nos bancos que negociam suas ações no Brasil e na Espanha.

É sabido que empresas que cotizam ações e demais títulos em bolsa de valores adotam regras de funcionamento e de divulgação de suas demonstrações contábeis ditadas por órgãos reguladores nacionais ou internacionais.

A fonte escolhida para a obtenção de informações dos bancos que desenvolvem suas operações no Brasil e que negociam suas ações foi a BM\&FBOVESPA e para os bancos que atuam na Espanha, a Bolsa de Valores da Espanha, Bolsa de Madri, onde foram listados os bancos considerados como abertos. Destaque-se que, neste estudo, serão utilizados os termos instituições financeiras, instituições bancárias e bancos como sinônimos.

O período de análise das informações foram os exercícios contábeis de 2006, 2007 e o primeiro semestre de 2008, 1S08, por meio das demonstrações contábeis, notas explicativas e relatórios de administração e demais relatórios financeiros de cada uma dessas entidades.

\subsection{Estrutura da dissertação}

Esta dissertação foi desenvolvida em cinco capítulos, sendo o primeiro composto pela contextualização do tema, definição da questão de pesquisa, os objetivos geral e específicos, a relevância do estudo e sua estrutura. 
No segundo capítulo há o referencial teórico, no qual é revista e discutida a bibliografia pertinente aos temas de Capital Intelectual, Ativo, Ativo Intangível, Goodwill e divulgação (disclosure) de informações, bem como a relevância do Capital Intelectual numa indústria de serviços como a bancária.

O terceiro capítulo discorre sobre a metodologia empregada, assim como a forma de escolha e seleção dos dados e os métodos qualitativos utilizados para o desenvolvimento da pesquisa.

O penúltimo capítulo mostra a interpretação dos dados obtidos por meio das análises das informações, encaminhando, dessa forma, para que sejam respondidos a questão de pesquisa, seu objetivo principal e os objetivos específicos.

O quinto capítulo apresenta a conclusão do trabalho e, também, algumas recomendações e sugestões para futuras pesquisas além da sugestão de extensão do tema pesquisado. 



\section{REFERENCIAL TEÓRICO}

\subsection{Contabilidade}

\subsubsection{Definição e objetivos da Contabilidade}

A Contabilidade, considerada nesta dissertação como uma Ciência e, ao mesmo tempo, um campo de estudo, possui uma série de definições. Entre as muitas existentes, a definição de Iudícibus (2006) é uma das mais consideradas e utilizadas em estudos acadêmicos brasileiros. O referido autor explica que a Contabilidade pode ser conceituada como o método de identificar, mensurar e comunicar informação econômica, financeira, física e social, a fim de permitir decisões e julgamentos adequados por parte dos usuários da informação.

Para Oliveira et al. (2003, p. 39), a Contabilidade é um conjunto sistematicamente formatado e apresentado de conhecimentos obtidos de forma metódica. Tais conhecimentos devem ser verificáveis e se referir a um projeto de estudo determinado, ou seja, no caso da Contabilidade, o objetivo a ser considerado é o patrimônio da entidade.

A definição dada por Lopes e Martins (2005, p. 125) indica que a Contabilidade pode ser explicada como "um sistema de informação e avaliação, destinado a prover seus usuários com demonstrações e análises de natureza econômica, financeira e de produtividade com relação à entidade em questão [...]."

Observe-se, por meio das definições apresentadas, que a Contabilidade possui uma função bastante ampla, na medida em que é responsável pelo fornecimento de informações de caráter operacional e não somente financeiro. Outro fato a ser enfatizado dentre as definições da Contabilidade, independentemente de suas funções, é que ela apresenta um método para que seus objetivos sejam atingidos e é tratada de maneira sistêmica.

A Contabilidade deve prover de informações econômico-financeiras os mais diversos usuários existentes de forma que propiciem decisões racionais. A principal maneira de provimento desse tipo de informação aos usuários é a divulgação de relatórios denominados como: 
demonstrativos contábeis, demonstrações financeiras ou demonstrações contábeis. (IUDÍCIBUS, 2006).

A informação oferecida pela Contabilidade por meio das demonstrações contábeis pode ser corroborada por Lopes e Martins (2005, p. 112), segundo uma visão pragmática baseada no Comitê Trueblood do AICPA, American Institute of Certified Public Accountants do FASB, Financial Accounting Standards Board:

\begin{abstract}
A informação contábil e os relatórios financeiros devem fornecer informações que são úteis para os atuais e futuros investidores e credores e outros usuários na tomada de decisões racionais sobre crédito, investimento e similares. Tais informações devem ser compreensíveis para todos aqueles que tiverem um entendimento razoável das atividades de negócios e econômicas e que estudarem tais relatórios adequadamente. Os relatórios financeiros devem fornecer informações para ajudar atuais e futuros investidores e credores na verificação das quantidades, tempo e incerteza dos recebimentos de caixa futuros advindos de dividendos ou juros e também dos recebimentos provenientes de vendas, ou maturidade de títulos ou empréstimos.
\end{abstract}

O estudo realizado pela ERNST YOUNG e FIPECAFI (2009) reforça a ideia discutida acima, pois informa que as demonstrações contábeis proveem informações sobre a posição financeira, o desempenho e as mudanças na posição financeira da entidade, dando suporte a avaliações e tomadas de decisão econômica. Ademais, pode-se considerar que as demonstrações financeiras, também, objetivam apresentar os resultados da atuação da administração na gestão da entidade e sua capacitação na prestação de contas quanto aos recursos que lhe foram confiados.

Outra entidade que menciona e explica o objetivo e a maneira como ocorrem as divulgações das informações por meio das demonstrações contábeis é o CPC, Comitê de Pronunciamentos Contábeis (2008), em seu Pronunciamento Conceitual Básico. Segundo o órgão, a função dos relatórios contábeis é prover informações sobre a posição patrimonial e financeira, o desempenho e as mudanças na posição financeira da entidade, que sejam úteis a um grande número de usuários em suas avaliações e tomadas de decisão econômica.

O Comitê, igualmente, destaca quais são os principais usuários dessas informações financeiras. Da mesma forma que Lopes e Martins (2005), o CPC considera como os possíveis usuários das demonstrações contábeis os atuais e potenciais investidores, colaboradores, credores, fornecedores, financiadores, acadêmicos, Governos e suas agências reguladoras e o público em geral. Esses usuários usam as demonstrações contábeis para 
satisfazer algumas das suas diversas necessidades de informação sobre a posição patrimonial da entidade e de que forma ela está inserida na sociedade.

Para reforçar essas firmas, pode-se utilizar como exemplo possíveis credores que desejem saber se uma determinada empresa possui capacidade de honrar suas obrigações, como também os empregados que precisam conhecer a capacidade de a empresa pagar seus vencimentos ao término do mês, o Governo que necessita conhecer a quantidade de receita que irá angariar em relação aos impostos pagos pelas entidades etc..

As demonstrações contábeis, segundo a Lei 11.638/07, compreendem o Balanço Patrimonial, a Demonstração de Resultado do Exercício, a Demonstração das Mutações do Patrimônio Líquido, Demonstração dos Fluxos de Caixa, Demonstração do Valor Adicionado, as Notas Explicativas, que têm por função elucidar os componentes dos relatórios contábeis e o Relatório de Administração, cuja finalidade é evidenciar informações adicionais que ajudem o usuário em seu processo de tomada de decisão que não são contempladas nos outros relatórios.

Cabe destacar a rubrica do CPC em seu Pronunciamento Conceitual Básico, no parágrafo 07, em que é descrito que:

as demonstrações contábeis não incluem itens como relatórios de administração, relatórios do presidente da entidade, comentários e análises gerenciais e itens semelhantes que possam ser incluídos em um relatório anual ou financeiro. As demonstrações contábeis são constituídas pelos relatórios contábeis propriamente ditos, conforme mencionado anteriormente.

Além das demonstrações contábeis, notas explicativas e Relatório de Administração, o conjunto que constitui as demonstrações financeiras, também, engloba quadros suplementares e demais relatórios que contribuam para o conhecimento do usuário das atividades desempenhadas pela empresa.

Ressalte-se que as entidades devem divulgar, além das informações tradicionais, outros dados que não possuam obrigatoriedade no Balanço Patrimonial e demais demonstrações, como, por exemplo, os investimentos em treinamentos de pessoal, investimentos em novos produtos e tecnologias etc.. (HENDRIKSEN; VAN BREDA, 1999). 
As informações sobre segmentos industriais ou geográficos de uma entidade podem ser citadas como exemplo, além do possível efeito positivo ou negativo de alterações de preços sobre a operação de uma determinada empresa ou variações cambiais. Todos esses dados devem ser mensurados e evidenciados sob a forma de informações suplementares.

Verifica-se, dessa forma, que os usuários possuem as mais diversas necessidades de informação e as demonstrações contábeis precisam atender de uma única forma todos os seus leitores, visto que seria impossível elaborar relatórios específicos para cada caso. Entretanto, sabe-se que as demonstrações contábeis não são munidas de todas as informações que os usuários possam necessitar, uma vez que elas retratam, muitas vezes, os efeitos financeiros de acontecimentos passados e não incluem, obrigatoriamente, informações não financeiras que possuem impacto no processo de tomada de decisão.

O CPC (2008) explana que uma importante função das demonstrações contábeis mas pouco citada na literatura é que os relatórios financeiros, também, objetivam apresentar os resultados da atuação da alta Administração na gestão da entidade, além de sua capacitação na prestação de contas quanto aos recursos que lhe foram confiados pelos principais interessados, geralmente os acionistas da empresa.

Entende-se por alta Administração, o conjunto de gestores e executivos da entidade, pessoas responsáveis pela condução e estratégia do negócio e cumprimento de sua missão. Os usuários que desejam avaliar a atuação ou prestação de contas da Administração fazem-no com a finalidade de estar em condições de tomar decisões econômicas que possam incluir, por exemplo, adquirir, manter ou vender seus investimentos na entidade ou reeleger ou substituir a própria Administração, dependendo da posição quanto ao controle e andamento das operações da companhia.

Cabe destacar que o Capital Intelectual não é um item comumente divulgado nas demonstrações contábeis, como balanço patrimonial, DRE etc.. Essa afirmação vai ao encontro do estudo de Edvinsson e Malone (1998), no qual mencionam que o Capital Intelectual não é um conjunto de informações que deve constar nas demonstrações contábeis tradicionais devido à dificuldade da mensuração de seus componentes, além da própria subjetividade nesse processo de avaliação. 
Dessa forma, pode-se inferir, previamente, que as informações sobre o Capital Intelectual poderiam ser detalhadas de forma melhor por meio das notas explicativas e dos relatórios de administração ou em relatórios apartados das demonstrações contábeis, pois não possuem uma sequência rígida e um grupo específico de classificação dentro dos relatórios contábeis.

\subsubsection{Contabilidade como sistema de informações}

As empresas são tratadas, muitas vezes, como organismos vivos, devido à visão sistêmica que é dada para a firma, segundo explica Riccio (1989) em sua tese de doutorado. Para Antunes (2004, p. 97), essa afirmação é verdadeira e a autora corrobora tal assertiva explicando que, segundo a abordagem sistêmica, as organizações são entendidas como organismos vivos, compostos por vários subsistemas que interagem entre si e com o meio externo numa relação recíproca de troca de materiais, de tecnologias, de conhecimento e de informações, cabendo à Contabilidade o papel de elo entre os subsistemas internos das organizações e entre essas e o meio externo.

Nakagawa (1993, p. 23), também, faz uso da comparação da entidade com um organismo vivo e uma entidade aberta. Essa ideia pode ser complementada aclarando que a entidade deve ser concebida sempre como um sistema aberto, pois se encontra em constante interação com os ambientes internos e externos, absorvendo, por exemplo, matérias-primas, recursos humanos, energia e informações, transformando-as em produtos e serviços, que são exportados para esses ambientes.

Ademais, a empresa pode ser considerada como um conjunto de subsistemas que estão em interação direta uns com os outros. Dessa forma, a análise dos fenômenos organizacionais não pode ser feita somente isolada e sim por meio do desempenho de cada subsistema que a compõe, quer sejam considerados em termos de coalizões, grupos, funções ou outros elementos conceituais dentro da empresa. (NAKAGAWA, 1993).

Um dos principais ferramentais para a análise da entidade é o emprego de Sistemas de Informação. Para Riccio (1989), Sistema de Informação pode ser definido como "um conjunto de subsistemas que atuam coordenadamente para, com o seu produto, permitirem às organizações o cumprimento de seus objetivos principais." 
O objetivo dos Sistemas de Informação é atingir a necessidade pela qual foram elaborados e desenvolvidos. Esse objetivo principal é representado por tudo aquilo que se quer que o sistema faça, ou seja, o que é aguardado do sistema. Seu resultado está diretamente relacionado com a responsabilidade ou missão dentro da organização e, dessa forma, entendese que todas as pessoas ligadas diretamente à organização que faz uso do sistema ou têm a seu cargo o gerenciamento de recursos, em partes maiores ou menores, dependendo da amplitude de cada função, possuem responsabilidade quanto ao seu funcionamento e bom desempenho. (Ibid., p. 138).

O autor explica, ainda, que a definição do objetivo do Sistema de Informação pode ser aclarada pelos seguintes itens aos quais chama de pontos de vista:

- $\quad$ O ponto de vista do analista, ou seja, o usuário que analisa um Sistema de Informação existente e que, portanto, quer confrontar os resultados atuais com os seus objetivos originais ou desejados para, então, identificar as modificações necessárias. Esse ponto de vista é denominado "Abordagem do Crítico".

- Outro ponto de vista é sobre quem constrói, concebe ou desenvolve um Sistema de Informação não existente até então. Esse ponto de vista é classificado como “Abordagem do Construtor”. Nesse caso, os objetivos são o ponto de vista de partida em que se origina todo o processo de construção do Sistema.

Apresentadas as definições de Sistemas de Informação, a utilização desses meios pela Contabilidade constitui o denominado SIC, Sistema de Informação Contábil. Nas palavras de Iudícibus (2006), o SIC pode ser explicado como: "um arquivo básico de informações contábeis, que possa ser utilizado de forma mais flexível por vários tipos de usuários, cada um com ênfases diferentes nos respectivos tipos de informações desejadas."

Os SIC são definidos por Riccio (2001, p. 16), em sua tese de livre-docência, da seguinte forma: "O Sistema de Informação Contábil é o conjunto de atividades que realiza as operações de coleta, processamento de dados e emissão de informações ou relatórios contábeis, financeiros, gerenciais e estratégicos, destinados à administração, ao fisco e aos demais órgãos externos à empresa." 
O SIC tem por objetivo prover informações monetárias e não monetárias destinadas às atividades e decisões dos níveis operacionais, tático e estratégico da empresa, e também para os usuários externos da entidade. Esse sistema deve constituir-se na peça fundamento do SIG, Sistema de Informação Gerencial, que engloba outros aspectos não contábeis da entidade.

Sendo a Contabilidade responsável pelo registro das alterações econômico-financeiras dentro da entidade, faz-se necessária a existência de um sistema que possa suprir os agentes internos da entidade de determinadas informações. Como exemplo, pode-se comparar o SIC a um veículo formal para o processamento operacional de dados contábeis e também para as demais atividades de suporte à decisão, sendo que todas as informações que alterem a entidade por meio da visão econômico-financeira devem transitar por esse veículo. (Id., 1989).

Antunes (2000, p. 66) informa que, tradicionalmente,

os Sistemas de Informações Contábeis possuem limitações e sua grande e maior função está na guarda e no registro de informações, apresentando pouca força na tomada de decisão e planejamento, mas devendo constituir-se na estrutura fundamental para o Sistema de Informação Gerencial. Os SIG, por sua vez, podem ser definidos como um agrupamento de sistemas que fornecem informações para apoio gerencial no processo de tomada de decisões.

Como área responsável pela centralização das informações monetárias e não monetárias, pode-se apontar a Controladoria que, fazendo uso de princípios, conhecimentos e métodos oriundos de outros departamentos do conhecimento e da organização, como a área que possui as bases teóricas necessárias à sua atuação na organização e também como incumbida de estruturar o sistema de informação gerencial de forma a contemplar as informações necessárias para conduzir as organizações ao cumprimento de sua missão. (Id., 2006, p. 25).

Cabe destacar o importante papel da tecnologia no âmbito desempenhado perante os Sistemas de Informação, sejam eles contábeis ou não. A tecnologia faz parte do andamento dos negócios de muitas entidades que utilizam os sistemas integrados para interligarem diversas partes e áreas da empresa. A TI, Tecnologia da Informação, revolucionou a operacionalização dos negócios empresarias pelas oportunidades trazidas com seu advento. 
Para corroborar tal afirmação, utiliza-se a afirmação de Brooking (1996, p.1 apud ANTUNES 2004, p. 26):

\begin{abstract}
A tecnologia da informação não substituiu apenas os métodos manuais de trabalho, mas permitiu a criação de novos serviços que não eram possíveis anteriormente [...]. Empregos têm novas formas de trabalhar, não precisam necessariamente estar fisicamente na empresa, comunicam-se por meio da tecnologia da informação. Isso possibilita que a empresa opere a custos reduzidos. [...] Para operar no ambiente atual, torna-se necessário trabalhadores com novas habilidades."
\end{abstract}

Destaque-se o fato de diversas empresas, principalmente as consideradas de grande porte, utilizarem a TI, por meio de sistemas computacionais, para contribuir ao cumprimento de suas atividades operacionais e estratégicas, englobando todas as informações quantitativas e, muitas vezes, qualitativas da organização. Dessa forma, presume-se que a Contabilidade é especialmente favorecida nesse processo, visto que, com a ajuda computacional, é permitida, por exemplo, a descentralização das contabilizações, a diminuição de possíveis erros de digitação e inserção de dados, além da mitigação de alguns riscos operacionais etc..

\title{
2.2 Ativo
}

O ativo é considerado como um dos componentes mais importantes da Contabilidade e, consequentemente, sempre foi alvo de estudos desde que essa passou a ser tratada como campo específico de conhecimento. Além disso, o ativo, também, é tratado em outras áreas do conhecimento como a administração, economia, engenharia de produção e outros.

Inúmeras são as definições dadas ao ativo e, igualmente, às suas divisões. Isso posto, faz-se necessária a visitação de algumas dessas definições, pois o Capital Intelectual pode ser entendido, inicialmente, como um recurso à disposição da entidade, ou seja, um ativo como os demais existentes. 
O IASB, International Accounting Standards Board, (2008, p. 82), define ativo da seguinte maneira: "ativo é um recurso controlado pela entidade como um resultado de eventos passados e do qual se espera que futuros benefícios econômicos resultem para a entidade."1

A definição dada pelo CPC é muito próxima àquela fornecida pelo IASB. Para o Comitê, o ativo pode ser entendido como um recurso que possui, essencialmente, as características de ser controlado por uma entidade, além de ser resultado de eventos passados e pelos quais se espera que produzam benefícios econômicos futuros para a entidade.

Cabe, também, destacar a figura FASB, órgão norte-americano que normatiza as práticas contábeis nos Estados Unidos da América. O FASB classifica o ativo como a forma de representar os possíveis benefícios futuros obtidos, controlados por uma determinada entidade como resultado de atividades ou eventos passados. (HENDRIKSEN; VAN BREDA, 1999).

Para Hendriksen e Van Breda (1999, p. 285), os ativos podem ser descritos como potenciais de fluxo de serviço ou direitos a benefícios futuros sob o controle da organização. Além disso, os autores afirmam que o Ativo possui três características essenciais:

- A incorporação de um benefício futuro provável que envolve a capacidade, isoladamente ou em combinação com outros ativos, de contribuir, direta ou indiretamente, à geração de entradas futuras líquidas de caixa.

- Uma dada entidade pode conseguir o benefício e controlar o acesso de outras entidades a esse benefício.

- A transação ou o evento originando o direito da entidade ao benefício ou seu controle sobre o mesmo já ocorrido.

\footnotetext{
1 "An asset is a resource controlled by the entity as result of past events and from which future economics benefits are expected to flow to the entity."
} 
Outra definição importante dada ao ativo é de Martins (1972, p. 30), na qual o referido autor sintetiza que o ativo pode ser considerado como o futuro resultado econômico que se espera obter de um agente.

Pode-se incluir, ainda, a definição de Lopes e Martins (2005, p. 118), em que o termo ativo é definido como: os itens que representam os possíveis benefícios futuros obtidos ou controlados por uma entidade com resultado de atividades ou eventos passados.

Destaque-se que, dentre essas definições dada ao ativo, os inúmeros pesquisadores e órgãos reguladores mencionam muitas características comuns a sua caracterização. Dentre elas, são descritas como essenciais a expectativa de geração de benefícios futuros, a ideia de recursos econômicos e o controle do ativo.

Em nenhuma das acepções dos autores citados foi mencionada a necessidade de propriedade como característica essencial para se classificar um item como ativo. Assim sendo, entendese, por exemplo, que um determinado ativo pode pertencer a uma entidade A e ser controlado e gerar benefícios para a entidade B. Infere-se, dessa forma, que esse ativo deve ser inserido no balanço da entidade que detém seu controle, ou seja, a segunda entidade.

Martins (1972, p. 41) enfatiza que o "ativo é representado no balanço patrimonial pelos itens que possuem valores econômicos para a entidade a que se refere." Isso posto, deduz-se que simplesmente o aparecimento de um elemento no ativo de uma empresa não significa, obrigatoriamente, que esse mesmo elemento, também, tenha significado econômico para qualquer outra.

Sobre esse tema, Iudícibus (2006, p. 140) afirma que sendo os ativos recursos econômicos alocados às finalidades do negócio, dentro de um período de tempo, e sendo agregados de potenciais de serviços disponíveis ou benefícios para as operações da entidade, o significado de alguns ativos somente pode ser relacionado aos objetivos da entidade e dependerá da sua continuidade.

O resultado econômico de um ativo deve estar relacionado a uma entidade especificamente, já que o uso público ou o favorecimento a muitos faz com que o recurso deixe de ter a caracterização como ativo, em muitas circunstâncias. Um dos exemplos clássicos é de um 
autoforno de uma indústria siderúrgica que só possui finalidade específica para determinadas empresas do setor de produção de aço.

A caracterização do ativo faz parte do processo contábil. Esse processo é composto por três fases ou etapas. Essas fases são classificadas da seguinte forma: reconhecimento, mensuração e evidenciação.

Sendo o Capital Intelectual considerado, inicialmente, como um ativo, já que acarreta benefícios econômicos para a entidade que o controla, faz-se necessária a discussão das fases que compõem o processo contábil.

\subsubsection{Reconhecimento}

O reconhecimento dos ativos é tratado na obra de Hendriksen e Van Breda (1999, p. 288). Para os referidos autores, basta um recurso, por exemplo, um ativo, surgir numa demonstração contábil, como o balanço patrimonial, para entender que esse item foi reconhecido. Tal assertiva, também, é valida para as obrigações de um modo geral, ou seja, os passivos.

Os autores explicam que não se registra um elemento ou grupo deles nas demonstrações contábeis se não for possível fazer sua respectiva medição, ou seja, sua mensuração. Dessa forma, conclui-se que, para que o ativo seja reconhecido, ele deve, necessariamente, ser mensurável nas demonstrações financeiras.

\subsubsection{Mensuração}

Para o entendimento do processo de mensuração, Iudícibus (2006) discute o conceito formulado pelo AAA, American Accounting Association, sobre mensuração. O órgão norteamericano informa que a medida de valor de um determinado ativo é a soma dos preços futuros de mercado dos fluxos de serviços a serem obtidos, descontados pela probabilidade de ocorrência e pelo fator juro, a seus valores atuais.

Entretanto, essa ideia de valor seria uma expressão ideal que possui bases práticas limitadas para a sua quantificação. Consequentemente, a mensuração dos ativos é, normalmente, realizada por outros métodos que servem como estimadores daquele método atual. 
A mensuração pode ser considerada como um processo contábil de atribuição de valores monetários significativos a objetos ou eventos associados a uma empresa e obtidos de modo a permitir agregação ou desagregação, quando exigida em situações específicas. Exemplos desses itens poderiam ser o grupo de contas a receber, instalações e equipamentos no balanço patrimonial.

Antes da realização da mensuração, porém, faz-se necessária a seleção de um atributo específico a ser medido. No caso de contas a receber, por exemplo, os atributos escolhidos poderiam incluir os montantes a serem recebidos e a data esperada de recebimento. Atributos dos grupos instalações e equipamentos poderiam incluir a capacidade física da produção, o dispêndio de recursos no ato de aquisição do maquinário ou os recursos necessários para repor os ativos no presente momento etc.. (HENDRIKSEN; VAN BREDA, 1999, p. 304).

A mensuração é efetivada por meio de termos monetários, ou seja, expressa em valores financeiros. Todavia, deve ser considerado que muitos itens não monetários como a capacidade de produção em toneladas de uma determinada indústria ou número de colaboradores de uma instituição financeira podem, muitas vezes, ser mais relevantes para certas predições à tomada de decisão do que um determinado item mensurável.

O capital humano é um exemplo que corrobora tal assertiva, pois seus valores não são mensurados nas demonstrações contábeis. Como os ativos possuem diversos atributos, a mensuração e publicação de mais de um atributo pode ser relevantes para os investidores, tomadores de decisão e demais usuários de demonstrações financeiras.

O Quadro 1, a seguir, destaca os meios de mensuração do ativo, segundo Hendriksen e Van Breda: 
Quadro 1 - Bases de mensuração

\begin{tabular}{|c|c|c|}
\hline & VALORES DE ENTRADA & VALORES DE SAÍDA \\
\hline Passados & Custos históricos & Preços de venda passados \\
\hline Correntes & Custos de reposição & Preço corrente de venda \\
\hline Futuros & Custos esperados & Valor realizável esperado \\
\hline
\end{tabular}

Fonte: Hendriksen e Van Breda - 1999, p. 304

\subsubsection{Valores de entrada}

As medidas de entrada representam, geralmente, o volume disponível, ou seja, dinheiro, ou, também, o valor de alguma outra forma de compensação, pago quando um ativo ou seus serviços ingressam na entidade por meio de uma troca ou conversão. Os valores de entrada podem basear-se em trocas passadas, trocas correntes ou trocas futuras esperadas. (HENDRIKSEN; VAN BREDA, 1999).

Já para Iudícibus (2006), os valores de entrada são mais adequados do que os valores de saída, como base geral de avaliação do ativo, pois podem representar o valor máximo para a empresa ou, ainda, porque, muitas vezes, não existe um mercado específico para os valores de venda. A seguir, são comentados sucintamente os principais valores de entrada adotados pela Contabilidade.

\subsubsection{Custo histórico}

Constitui uma das formas de valoração dos Ativos mais utilizadas pela Contabilidade, segundo explicação de Iudícibus (2006) e Hendriksen e Van Breda (1999). O custo histórico é um dos meios de mensuração mais usados no Brasil até o advento da Lei 11.638/07 que alterou a Lei 6.404/76, que inseriu na legislação outras formas de mensurar os itens de ativos, passivo e patrimônio líquido.

A mensuração do custo histórico é definida por meio do preço agregado pago pela empresa para adquirir a propriedade, controle e o uso de um ativo, incluindo todos os pagamentos necessários para colocar o ativo no local e nas condições que permitam prestar serviços na produção ou em outras atividades da empresa. 


\subsubsection{Custos correntes}

Pode-se afirmar que tanto os custos históricos quanto os custos correntes são iguais na data de incorporação de um determinado ativo, porém, à medida que os preços mudam e a tecnologia fica mais sofisticada com o decorrer do tempo, podem ocorrer variações nesses preços. (IUDÍCIBUS, 2006, p. 149).

O custo corrente pode ser definido como o somatório dos custos atuais de insumos contidos em um bem, custos esses equivalentes aos do originariamente adquirido menos sua respectiva depreciação. Além disso, o custo histórico pode, em certas circunstâncias, ser relevante como substituto do custo corrente de um ativo. O custo corrente pode, por sua vez, ser um substituto do valor presente dos fluxos de caixa futuros, que é o atributo que, realmente, se deseja medir do ativo em questão.

Os custos correntes representam o preço de troca que seria exigido, atualmente, para obter o mesmo ativo equivalente. Se houver um mercado no qual os ativos semelhantes sejam comprados e vendidos, um preço de troca poderá ser obtido e associado ao ativo possuído.

\subsubsection{Custos históricos corrigidos}

O custo histórico corrigido apresenta a vantagem ante o custo histórico original devido a sua fácil utilização e também pelo fato de avaliar o patrimônio líquido da entidade com maior potencialidade, segundo as palavras de Iudícibus (2006). Esse item de medida de entrada pode ser definido como o custo histórico original acrescido de valores que recuperem a perda do valor do dinheiro no tempo.

\subsubsection{Custo corrente corrigido}

Considerado como um dos mais completos conceitos de avaliação de ativos a valores de entrada, o custo corrente corrigido agrega as vantagens do custo corrente com as do custo histórico corrigido. O custo corrente corrigido consiste em avaliar os ativos em determinada data a valores correntes, também conhecidos como valores de reposição, levando-se em conta seus valores econômicos e não seus valores contábeis. 


\subsubsection{Valores de saída}

Os valores de saída, também, são chamados de medidas de saídas. Essas medidas de saída ou os preços de saída representam o volume de caixa ou o valor de algum outro instrumento de pagamento, recebido quando um ativo ou seu serviço deixa a empresa por meio de troca ou conversão.

Hendriksen e Van Breda (1999) explicam que o valor dos ativos, com fluxo de caixa esperado descontado, deve ser a medida de interesse quando são usados dados de saída. Quando o produto de uma empresa é, geralmente, vendido em um mercado organizado, o preço corrente de mercado pode ser uma estimativa razoável do preço efetivo de venda no futuro próximo. Entretanto, se não se espera que o produto seja vendido em curto prazo, o preço corrente de mercado deve ser, adequadamente, descontado.

\subsubsection{Preços correntes de venda}

O preço corrente de venda é aquele comercializado em um mercado organizado, ou seja, em que as partes relacionadas sejam conhecedoras e a comercialização seja forçada. O método, Igualmente, é conhecido como valor realizável líquido e é muito praticado no Brasil, segundo Iudícibus (2006). Todavia, o autor comenta que o método tem suas limitações, pois não pode ser utilizado como conceito geral de avaliação de ativos.

\subsubsection{Equivalentes correntes de caixa}

O conceito de valor de saída denominado equivalentes correntes de caixa equivale ao total do montante de recursos obtidos vendendo cada ativo sob condições de liquidação ordenada. Um exemplo dessa aplicação são equipamentos especializados não vendáveis, como ativos intangíveis. (HENDRIKSEN; VAN BREDA, 1999).

\subsubsection{Evidenciação (Disclosure)}

A evidenciação ou divulgação é, comumente, citada por seu equivalente no idioma em inglês, o termo disclosure e também serão tratados neste trabalho como sinônimos. A divulgação ou disclosure consiste em informar determinada característica ou conjunto de características de um dado elemento ou grupo de elementos. 
A divulgação compreende a veiculação da informação, ou seja, que ela possa ser conduzida mediante algum meio. É importante frisar que a evidenciação está ligada aos objetivos da Contabilidade, pois, dessa maneira, garante o suprimento de informações diferenciadas para os vários tipos de usuários.

Isso posto, pode-se afirmar que o termo evidenciação é limitado ainda quando se refere às informações não contidas nas próprias demonstrações financeiras. De modo geral, a divulgação, em seu sentido mais estrito, trata de itens como a discussão de uma série de fatores, como capacidade produtiva, ociosidade de colaboradores e outros.

É importante mencionar a necessidade de que haja pelas entidades uma ampla divulgação das informações financeiras e não financeiras para que os usuários possam usufruir melhor as demonstrações contábeis e outros relatórios financeiros para sua tomada de decisão.

Iudícibus (2006) menciona, em sua obra, que há quase 50 anos o AICPA já estabelecia que os relatórios contábeis deveriam evidenciar o que for necessário a fim de não torná-los enganosos, ou seja, que mostrem a verdadeira situação da entidade não somente pelos seus balanços patrimoniais, demonstrações de resultado, demonstração dos fluxos de caixa, mas, também, por meio de outras informações que reforcem a real condição econômico-financeira da empresa.

O tipo, a quantidade e a qualidade de evidenciação dependem, em parte, do quão sofisticado o leitor ou usuário das demonstrações contábeis possa ser. Com relação à "quantidade" de evidenciação, muitas expressões e conceitos têm sido utilizados pelas empresas. São citadas a evidenciação adequada (adequate disclosure), evidenciação justa (fair disclosure) e outros ainda em evidenciação plena de informações (full disclosure). (Ibid., p. 152).

Para Nossa (2002, p. 179), "o tipo de Disclosure pode ser definido como a maneira pela qual a informação é apresentada nos relatórios”. Para ele, os tipos de disclosure podem assim ser considerados:

- Nulo: quando nenhuma informação for apresentada em relação à determinada categoria específica; 
- Declarativa: quando somente a informação qualitativa é apresentada e expressa em termos puramente descritivos;

- Quantitativa não monetária: quando a informação quantitativa é apresentada e expressa em números de natureza não financeira;

- Quantitativa monetária: quando a informação quantitativa é apresentada e expressa em números de natureza financeira;

- Quantitativa monetária e não monetária: quando a informação quantitativa é apresentada e expressa em números de natureza financeira e não financeira.

Em verdade, acredita-se que não há diferença entre esses conceitos sobre a evidenciação, embora, normalmente, sejam utilizados com significados distintos. O sentido da evidenciação é que a informação que não for relevante deve ser omitida a fim de tornar as demonstrações contábeis significativas e possíveis de serem entendidas plenamente. (IUDÍCIBUS, 2006).

Lopes e Alencar (2008) afirmam que há uma importante vertente da contabilidade financeira que investiga a relação entre a divulgação das informações e o custo de capital próprio e outros itens. Para os autores, a ideia básica é que níveis mais elevados de divulgação de informações podem contribuir para reduzir a assimetria de informações entre gestores e investidores e, consequentemente, provocar uma redução no componente idiossincrático do custo dos capitais próprios.

Infere-se que as informações que não sejam relevantes ou que não possuam utilidade para nenhum tipo de usuário devem ser omitidas das demonstrações contábeis para que elas não se constituam num documento muito extenso e sem serventia específica aos seus leitores.

Para que informações desnecessárias não corram o risco de serem divulgadas, devem-se levar em conta os conceitos de materialidade e relevância, pois eles estão fortemente ligados à evidenciação de dados. 
No que tange à evidenciação das informações quantitativas, vários critérios têm sido utilizados, como a representatividade percentual de um item sobre o lucro líquido, sobre a receita bruta ou sobre outro item qualquer da demonstração dos resultados. Já a informação qualitativa possui maior dificuldade em ser avaliada em relação à informação quantitativa, pois envolve vários julgamentos extremamente subjetivos.

Deve-se atentar ao fato de que, antes de evidenciar um determinado evento, item ou conjunto de itens não quantificáveis, é preciso avaliar, se essas informações aumentarão a relevância a ponto de justificar o aumento da complexidade de sua análise da entidade como um todo.

Iudícibus (2006, p. 126) explica que, embora a evidenciação se refira a todo conjunto das demonstrações contábeis, outras formas de realizar a evidenciação estão disponíveis. As principais são:

- $\quad$ Forma e apresentação das demonstrações contábeis;

- Informações entre parêntesis - que detalham especificamente um item a ser analisado;

- Notas explicativas;

- Quadros e demonstrações suplementares;

- Comentários do auditor e

- Relatório de administração.

A visão de Hendriksen e Van Breda (1999, p. 511) a respeito desse tema vai ao encontro à de Iudícibus (2006), pois mencionam que a divulgação financeira deve fornecer informação útil à tomada de decisões racionais de investimento, concessão de crédito por investidores atuais e futuros, bem como outros usuários, ou seja, que informações sem relevância não devem ser divulgadas nas demonstrações contábeis. A Ilustração 1 exemplifica como ocorre o processo de divulgação financeira. 


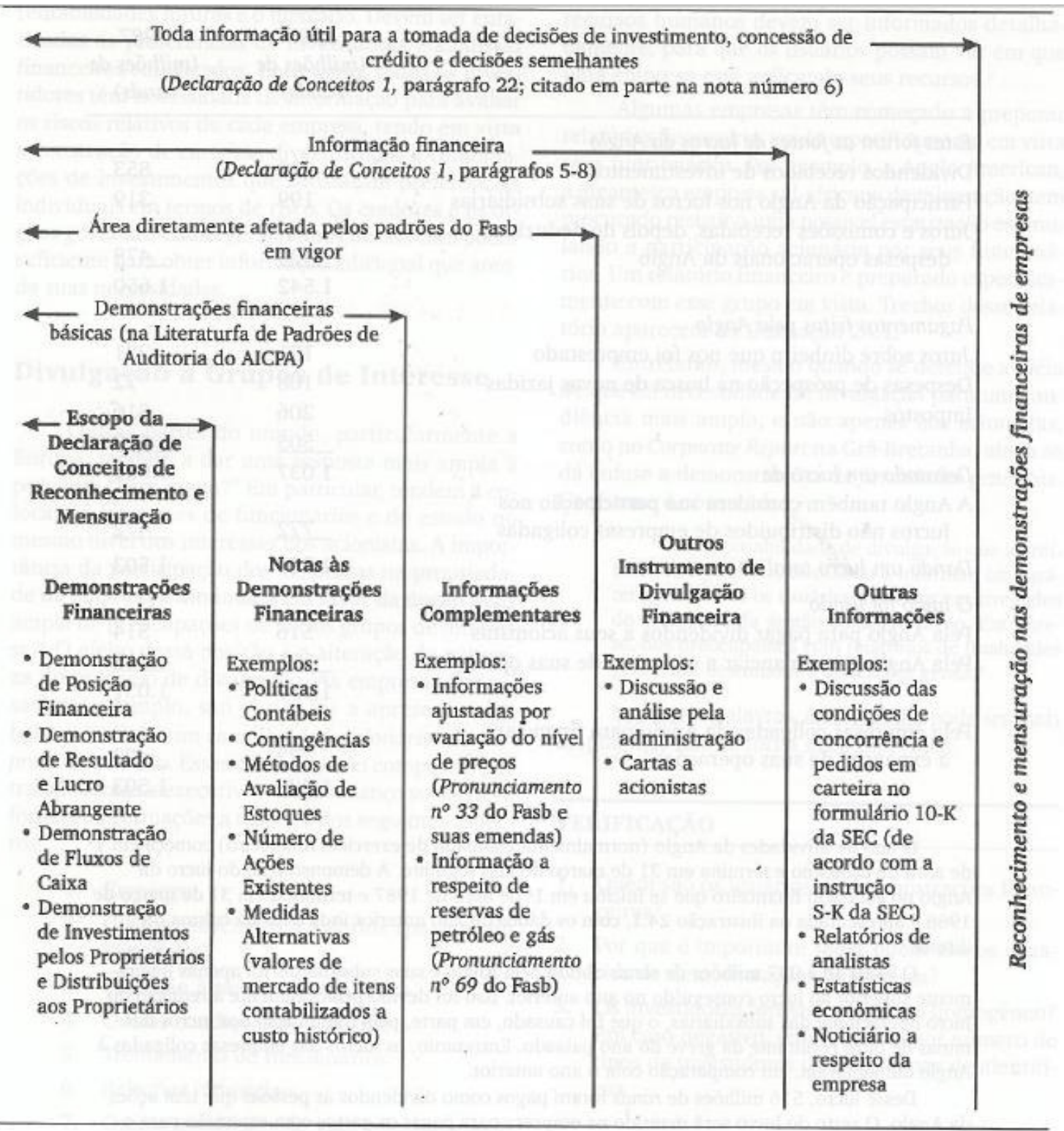

Ilustração 1 - Divulgação financeira

Fonte: Hendriksen e Van Breda, 1999, p. 514

Em relação ao relatório de administração, destaca-se o fato de essa peça informativa englobar, normalmente, informações de caráter não financeiro que afetam a operação da empresa como, por exemplo, expectativas com relação ao futuro no que se refere à própria empresa e ao seu setor de atuação, planos de crescimento da companhia e valor de gastos efetuados ou a efetuar no orçamento de capital ou pesquisa e desenvolvimento.

Outras informações de caráter não financeiro ou qualitativo, igualmente, vêm sendo evidenciadas no relatório de administração das entidades como as informações de impacto ambiental de determinadas indústrias decorrentes de suas operações como, também, as 
atitudes quanto à conservação do meio ambiente que instituições financeiras, por exemplo, adotam nos últimos tempos.

Não obstante, as demonstrações contábeis propriamente ditas evidenciam em seu corpo, geralmente, somente os itens considerados "tradicionais" pela Contabilidade. No Brasil, por exemplo, a partir da Deliberação CVM n. 488/2005, os ativos intangíveis deveriam ser divulgados apartados do Ativo Imobilizado e considerados como subgrupo do ativo permanente. A partir de então, presume-se que aumentou a quantidade de informações divulgadas em relação ao ativo intangível no próprio balanço patrimonial e, consequentemente, nas notas explicativas.

De qualquer forma, nem todos os ativos são passíveis de tal divulgação. Martins (1972, p. 33) afirma que: "também se enquadram como ativos todos os recursos humanos, quer os dirigidos pela administração, quer os dirigidos para a produção de bens ou serviços ou outras funções."

Segundo o autor, esses ativos são recursos para os quais se espera resultados econômicos futuros de forma individual. Considerando que os recursos humanos são ativos da entidade que possui essa força de trabalho, infere-se que deveriam ser evidenciados no próprio balanço patrimonial.

Para Martins (1972) essa assertiva é válida, visto que para o autor os colaboradores de uma entidade, também, são recursos econômicos, ativos econômicos e, portanto, merecedores de reconhecimento como ativos contábeis.

Por sua vez, Edvinsson e Malone (1998, p. 21) asseguram que os ativos constituem toda a propriedade de uma empresa e que podem ser expressos por um determinado valor. Os ativos apresentam-se, segundo esses autores, sob quatro formas: três delas são precisas e de fácil mensuração e a quarta imprecisa e essencialmente não mensurável até que seja vendida ou negociada.

Os autores supracitados definem que as duas primeiras categorias de ativos são os circulantes, significando que, provavelmente, serão utilizados ou vendidos dentro de um ano, como, por exemplo, os estoques e as contas a receber, e os ativos imobilizados (ou outros de longa 
duração), os quais, sob a forma de plantas industriais, equipamentos ou imóveis, possuem uma vida útil superior a um ano ou exercício contábil.

Os ativos permanentes, tendo em vista que seus valores são utilizados aos poucos ao longo dos diversos períodos em que são preparadas as demonstrações contábeis, são depreciados, isto é, seus custos são distribuídos de uma maneira razoável e sistemática em balanços patrimoniais sucessivos ao longo do tempo.

A terceira categoria de ativos, segundo Edvinsson e Malone (1998) é constituída pelos investimentos, como as ações e obrigações de propriedade de uma empresa. Embora essa categoria de ativo seja comumente mais volátil que as duas primeiras, ela, no entanto, pode ser avaliada de uma maneira sistemática por meio do valor de mercado e de outros parâmetros.

A quarta categoria de ativo, no entanto, é considerada muito mais problemática e de difícil mensuração. Os ativos intangíveis, para esses autores, são aqueles que não possuem existência física, mas, de qualquer forma, representam valor para a empresa que os controla.

Esse grupo de ativos é, tipicamente, de longo prazo e de difícil avaliação e só aparecem precisamente no momento em que a empresa é vendida, pois o comprador, eventualmente, capta o valor desse grupo de ativos.

Assim sendo, cabe visitar a bibliografia existente sobre o Ativo Intangível, buscando suas definições como, também, seu tratamento, mensuração e evidenciação.

\subsubsection{Desreconhecimento de Ativos (Asset Derecognition)}

A literatura é muito vasta sobre o tema reconhecimento de ativos, todavia, o desreconhecimento de um ativo é, até agora, pouco explorado seja nas pesquisas brasileiras ou internacionais.

Segundo o documento de "Proposed amendments to IAS 39 and IFRS 7" do IASB (2009), o desreconhecimento pode ser definido como o fato ou ato de deixar de reconhecer que o ativo ou a responsabilidade de uma determinada entidade sobre uma posição financeira específica. 
Cabe destacar que o desreconhecimento tratado pelo documento acima é utilizado, especificamente, para os instrumentos financeiros. Um termo, também, utilizado pelo IASB em seu Proposed amendments to IAS 39 and IFRS 7" é "transferência". Segundo o órgão internacional, a transferência ocorre quando uma das partes de uma determinada negociação econômico-financeira passa, ou aceita a passagem, para outra parte negociadora de alguns ou todos os benefícios econômicos subjacentes a um ou mais dos seus ativos.

É importante mencionar que o termo transferência é utilizado, amplamente, para incluir todas as formas de venda, cessão, fornecimento de colateral, sacrifício de benefícios, distribuição e outras intercâmbio. O IASB salienta que a transferência de ativos não resulta, necessariamente, em "derecognition".

Para o IASB (2009), uma entidade deve desreconhecer um ativo se um desses três itens ocorrerem:

- Os direitos contratuais aos fluxos de caixa previstos desse ativo (ou grupo de ativos) expirarem;

- Se a entidade transferir o ativo (ou grupo de ativos) e não haja mais nenhum envolvimento contínuo com ele ou

- A entidade transfere o ativo (ou grupo de ativos) e mantém uma contínua participação com esse ativo ou grupo de ativos, mas a entidade que recebeu a transferência desse ativo possui a habilidade prática de transferir para si mesma os benefícios econômicos desse ativo ou grupo de ativos.

\subsection{Ativo intangível}

O entendimento do ativo intangível sempre figurou com certa dificuldade nos estudos contábeis. É sabido, porém, que muitos segmentos de indústrias e, principalmente, as empresas de serviços, possuem ou deveriam possuir itens classificados como ativos intangíveis como parte de seus ativos totais. 
Essa afirmação pode ser embasada por meio dos estudos realizados pela Ernst \& Young e Fipecafi (2009), nos quais é explicado o fato notório de que, em muitos segmentos de negócios, a maior parte da geração de valor está atrelada, justamente, à parcela intangível dos ativos que uma entidade detém.

Para ilustrar a existência de uma série de ativos intangíveis nas empresas, menciona-se o exemplo das indústrias farmacêuticas, companhias de alta tecnologia, desenvolvedoras de programas de computador e produtoras de websites que refletem bem essa realidade contemporânea.

Outro fato relevante é que, em praticamente todas as fusões e aquisições de empresas, a diferença entre o patrimônio líquido contábil e o custo de aquisição é bastante significativa, não apenas dos ativos intangíveis que possuem valor, mas que, muitas vezes, não são reconhecidos ou têm seu reconhecimento subestimado.

Como consequência, a regulação relativa ao reconhecimento, mensuração e evidenciação dos ativos intangíveis evoluiu ao longo do tempo, sempre buscando o equilíbrio entre duas de suas características qualitativas que a informação contábil deve apresentar: relevância e confiabilidade.

Todavia, destaque-se o ponto de que tais objetivos são extremamente difíceis de serem alcançados pela Contabilidade em relação a qualquer elemento patrimonial e, em especial, aos ativos intangíveis, visto que, para esses itens, há maior complexidade em realizar essas tarefas de reconhecimento, mensuração e evidenciação.

A relevância, em Contabilidade, consiste em promover uma informação com maior previsibilidade, auxiliando na projeção de fluxos de caixa futuros e no seu reconhecimento oportuno. Já a confiabilidade está calcada no atributo de verificabilidade, sendo uma importante restrição ao reconhecimento dos ativos intangíveis, principalmente aos que são gerados internamente pela entidade.

Quanto à origem dos ativos intangíveis, Lev (2001) menciona que eles não são um fenômeno novo na Contabilidade e no mundo corporativo. Segundo o autor, desde o início da civilização, os ativos intangíveis eram criados à medida que as transações econômico- 
financeiras eram realizadas e pesquisas eram feitas. $\mathrm{O}$ autor cita as importantes descobertas pelo homem, como as invenções da eletricidade, telefone, motor a combustão interna, produtos farmacêuticos etc..

Há um forte incremento dado ao destaque atribuído aos ativos intangíveis nos últimos tempos, seja em relação ao seu valor financeiro como também a sua utilidade na operação das entidades e no prosseguimento de seus negócios. Saliente-se, também, a quantidade de estudos derivados do ativo intangível oriundos do meio acadêmico. Tudo isso pode ser considerado resultado de três grandes vertentes, as mudanças substanciais na estrutura das empresas e de longo alcance da tecnologia da informação e inovações científicas.

Uma das grandes características dos ativos intangíveis é a sua diferença em relação aos ativos ditos como tangíveis ou corpóreos (MARTINS, 1972; MONOBE, 1986; LEV, 2001). Para que esse tema seja mais aprofundado, é necessário que se faça uma análise mais complexa da economia que abranja os bens intangíveis, uma compreensão dos incentivos e motivações dos principais players das empresas que fazem uso intensivo desses ativos intangíveis e das consequências econômicas que a sua utilização traz para a empresa.

Quanto à mensuração dos ativos intangíveis, Lev (2001, p. 77) destaca que são utilizadas diversas medidas de entrada e saída de para sua realização. Diz ainda o autor que o "valor dos ativos intangíveis serve como ferramenta de avaliação de o desempenho corporativo e de valor da entidade."

Para que haja a adequada divulgação dos itens dos ativos intangíveis, faz-se necessária a construção de uma estrutura global e coerente que concentre informações essenciais sobre a criação, o valor do processo da empresa, inserindo os ativos intangíveis dentro dessa estrutura. (Ibid., p. 80).

O IASB criou, em setembro de 1998, uma norma que trata, exclusivamente, do tratamento que deve ser dispensado aos ativos intangíveis: a IAS, International Accounting Standard 38Intangible Assets. Conhecedor das dificuldades existentes entre as entidades para o tratamento do ativo intangível, a norma elaborada pelo órgão deve ser seguida por todas as entidades que possuam ou controlem ativos intangíveis em suas operações e que os divulguem em suas demonstrações contábeis. 
Estudos da CVM (2008) mostram que, de forma geral, não há uma norma contábil específica e detalhada no Brasil que determine como devem ser reconhecidos, classificados e avaliados os ativos intangíveis, nem há literatura, trabalhos acadêmicos nacionais ou orientação sobre a apresentação e divulgação desses ativos nas demonstrações financeiras das empresas brasileiras.

O que existe, atualmente, é o Pronunciamento n. 04 do CPC, que trata dos Ativos Intangíveis, e as orientações da CVM, por meio da emissão de ofícios-circulares que resumem e incentivam a utilização dos conceitos do IFRS e pequenas citações em pronunciamento do IBRACON, Instituto dos Auditores Independentes do Brasil, especificamente o Pronunciamento VIII.

Ernst \& Young e Fipecafi (2009) mencionam que a IAS 38, ao mesmo tempo em que permite o reconhecimento de inúmeros ativos intangíveis, acaba por ser mais criteriosa, do que o tratamento dado até ser colocada em prática, visto o maior grau de exigência e verificabilidade para seu reconhecimento. É citado, ainda, que a norma IAS 38 é mais específica e criteriosa que a IAS 16 (Ativos Intangíveis).

Como exemplos de ativos intangíveis, Carvalho et al. (2006, p. 66) citam os softwares de computador, licenças, marcas, patentes, filmes, direitos autorais, quotas de importação, lista de clientes, licença de pesca, franquias, relacionamento com clientes e fornecedores, lealdade de clientes, participação no mercado (market share) e direitos de marketing.

\subsubsection{Definição de ativo intangível}

Para explicar o significado do ativo intangível, Lev (2001, p. 5) invoca em seu trabalho o significado da palavra intangível que, segundo o dicionário Webster pode ser caracterizado como "incapaz de se definir ou determinar com certeza ou precisão."2

Como ativo intangível, Lev (2001) define o mesmo como sendo expectativas de benefícios econômicos futuros derivados de um item que não possui estrutura física. Como exemplo,

\footnotetext{
${ }^{2}$ Incapable of being defined or determined with certainty or precision
} 
também cita as marcas, patentes e a uma estrutura organizacional que sofrem investimentos pela empresa como sendo ativos intangíveis.

Hendriksen e Van Breda (1999, p. 388) explicam que a palavra intangível possui origem no latim tangere, ou "tocar". Monobe (1986, p. 42) também cita a mesma palavra grega, esclarecendo que o termo tangível originou-se do latim "tango" (tocar), significando literalmente perceptível ao toque.

A despeito dessa visão, o termo intangível significa algo não perceptível ao toque, o que acarretaria a definição de ativo intangível como aquele que possui valor econômico, mas carece de substância física, isto é, constitui-se de ativo sem existência corpórea. (Id., 1986).

A IAS 38 define ativo intangível como:

um ativo não monetário identificável e sem substância física. A definição de ativo pela norma é a mesma da estrutura conceitual, uma vez que um ativo é um recurso controlado pela entidade como resultado de eventos passados e do qual são esperados benefícios futuros para a entidade.

Hendriksen e Van Breda (1999, p. 388) dizem que os ativos intangíveis são definidos, em certas ocasiões, como a diferença positiva entre o custo de uma empresa adquirida e a soma de seus ativos tangíveis líquidos. Entretanto, isso e equivalente a confundir mensuração e definição.

A Lei 11.638/2007 define os Ativos Intangíveis como direitos que tenham por objeto bens incorpóreos destinados à manutenção da Companhia ou exercidos com essa finalidade, inclusive o fundo de comércio adquirido.

Já Martins (1972, p. 53), por sua vez, menciona que

a divisão entre ativos tangíveis e intangíveis tem sido a dificuldade em defini-los, reconhecê-los e mensurá-los. Um ativo intangível é um ativo não-monetário identificável sem substância física, mantido para uso na produção, ou suprimento de bens ou serviços, para ser arrendado ou para fins administrativos.

As entidades, frequentemente, despendem recursos ou contraem obrigações com a aquisição, o desenvolvimento, a manutenção ou o aprimoramento de recursos intangíveis, como: conhecimento científico ou técnico; desenho e implantação de novos processos ou sistemas; 
licenças; propriedade intelectual; conhecimento mercadológico; nome; reputação; imagem e marcas registradas (incluindo nomes comerciais e títulos de publicações).

Em sua obra, Lev (2001) afirma que as empresas desse século não apenas são mais "conectadas" que suas predecessoras da era industrial, como, também, são mais dependentes de seus empregados, na medida em que agregam conhecimentos aos processos produtivos e à administração em geral.

Já Sveiby (1997, p. 8) denomina os ativos intangíveis como "ativos invisíveis". Segundo o autor, as pessoas são os únicos verdadeiros agentes existentes na empresa. Todos os ativos e estruturas da entidade - considerados como tangíveis e intangíveis - são o resultado das ações humanas. Dessa forma, tudo dependerá, em última instância, das pessoas e suas atitudes para com a entidade para a geração de resultados e, consequentemente, riqueza para a empresa.

\subsubsection{Reconhecimento e mensuração do ativo intangível}

O reconhecimento de ativos intangíveis nas demonstrações financeiras sempre foi um tópico polêmico e de controvérsias no mundo acadêmico. A tradição normativa da Contabilidade tem sido a de restringir o reconhecimento de certos ativos e, em troca, ampliar a divulgação de todos os elementos que ajudem os usuários a entender a posição patrimonial e suas mutações, a projetar para o futuro e a efetuar suas próprias avaliações, em vez de colocar sobre a empresa a responsabilidade e autoridade para assumir essa tarefa, conforme explicam Ernst \& Young e Fipecafi (2009).

O estudo sobre as Normas Internacionais de Contabilidade realizado pela CVM (2008), clarifica que o reconhecimento de um ativo intangível, de acordo com a Norma IAS 38, é baseado no princípio do reconhecimento geral aplicável aos custos incorridos inicialmente para adquirir ou gerar internamente um ativo intangível e aqueles incorridos subsequentemente.

Apesar da IAS 38 não definir o termo "provável", esse é definido em diversas outras Normas Internacionais como more likely than not - expressão sem equivalente literal em português. É importante notar que, para fins de reconhecimento, a IAS 38 não distingue entre ativos intangíveis desenvolvidos interna ou externamente. Ambos os ativos devem ser reconhecidos 
como ativos intangíveis no momento em que atingem os critérios de definição e reconhecimento.

Com relação a gastos subsequentes, a IAS 38 menciona que a natureza do ativo intangível é tal que, em muitos casos, não existem adições a tal ativo ou reposições de parte dele. Dessa forma, a maioria dos gastos subseqüentes, normalmente, deve manter os benefícios econômicos futuros em relação a um ativo intangível existente em vez de atingir os critérios de definição e reconhecimento.

A IAS 38 assume que, apenas raramente, um gasto subsequente incorrido será reconhecido como parte do valor contábil do ativo intangível. A capitalização de gastos subsequentes com marcas, nomes comerciais, títulos de publicações, lista de clientes e itens similares é expressamente proibida. Isso porque a Norma argumenta que tais itens não podem ser diferenciados do negócio do qual fazem parte. Sendo assim, no máximo, tal gasto cria um ágio gerado internamente, que não é reconhecido como ativo.

A Ilustração 2, a seguir, mostra o processo de reconhecimento dos Ativos Intangíveis. 


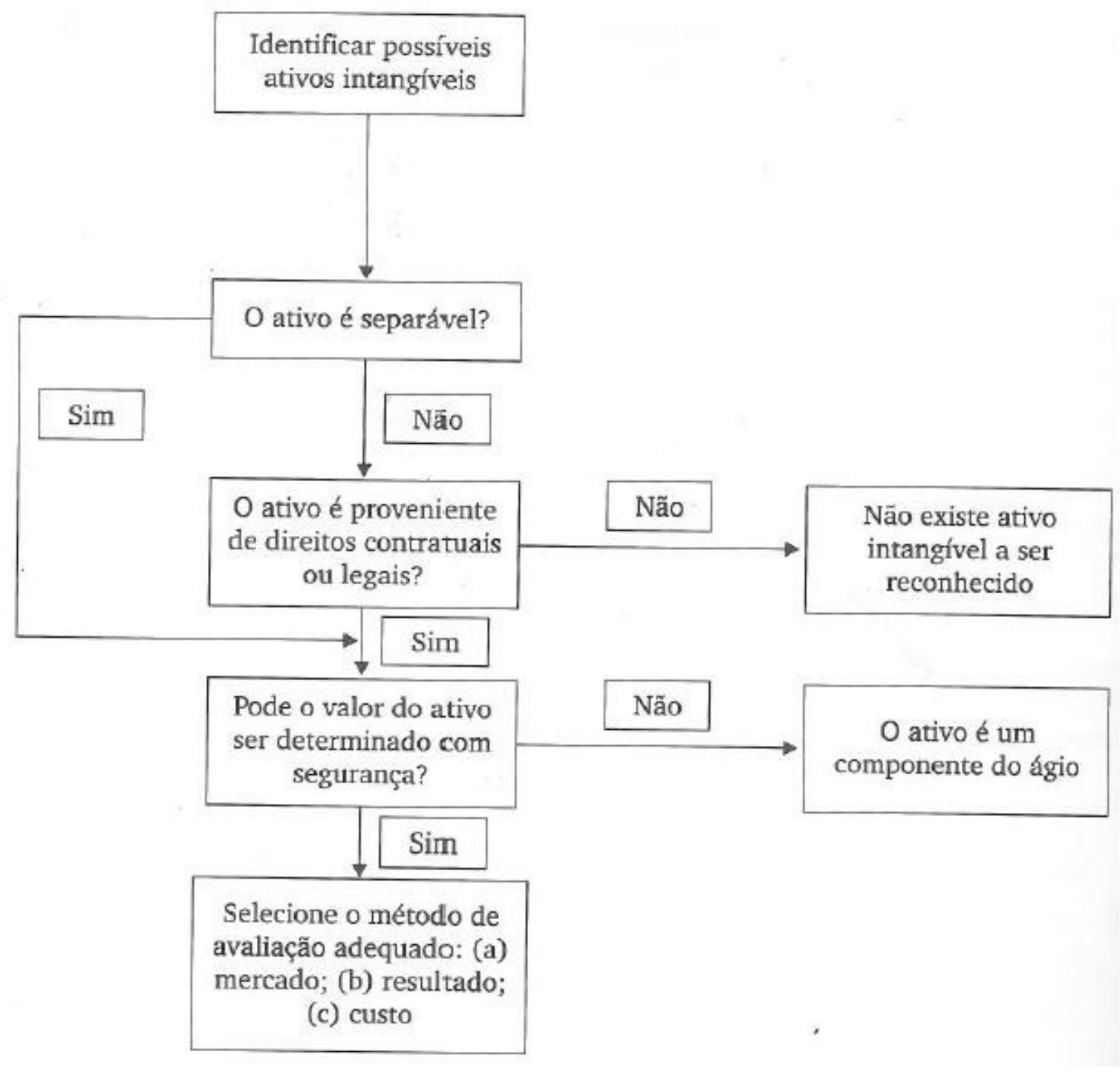

Ilustração 2 - Divulgação financeira

Fonte: Ernst \& Young e Fipecafi, 2009, p. 328

Hendriksen e Van Breda (1999, p. 388) explicam que o reconhecimento dos intangíveis deve ser realizado, mesmo que esses itens não apresentem substância física. Seu reconhecimento deve obedecer, portanto, às mesmas regras válidas para todos os demais ativos considerados como tangíveis.

O Pronunciamento CPC n. 04 informa que o reconhecimento de um item como ativo intangível exige que a entidade demonstre que ele atende aos seguintes requisitos:

- A definição de ativo intangível.

- $\quad$ Acate os critérios de reconhecimento de ativo. 
Os ativos intangíveis passem pelos mesmos testes de reconhecimento aplicados aos ativos tangíveis. Caso sejam aprovados em todos esses testes, os ativos os intangíveis deverão ser evidenciados nas demonstrações financeiras.

Dessa maneira, muitos itens do ativo intangível poderiam ser inseridos no balanço patrimonial ao invés de receberem tratamento como despesas, tais como custos de pesquisa e desenvolvimento e propaganda e outros.

O tratamento de intangíveis não identificáveis tem maior complexidade. Ativos não identificáveis são desprovidos de interpretação semântica e, assim, não passam pelo teste de relevância e, consequentemente, não devem ser reconhecidos.

No entanto, de acordo com a estrutura contábil tradicional, se houver uso de recursos para beneficiar períodos futuros, o custo deverá ser capitalizado e alocado aos períodos contábeis futuros. De outra forma, todos os ativos intangíveis adquiridos tendem a ser capitalizados na prática, satisfaçam o critério de relevância ou não.

\subsubsection{Alterações no reconhecimento do ativo intangível no Brasil pelo CPC 04 -} tendo como base a IAS 38

O trabalho da CVM (2008) sobre as Normas Internacionais de Contabilidade elenca as possíveis alterações que o Brasil vai sofrer em introduzir a IAS 38 para o reconhecimento e tratamento de ativos intangíveis. A utilização do IAS 38 pelo Brasil e de outros pronunciamentos correlatos, como o IFRS 3, poderá culminar no reconhecimento, na mensuração e na evidenciação de uma série de ativos intangíveis, algo que seria relativamente novo para o país.

Destaque-se que a IAS 38 não possui, até o presente momento, enforcement para ser aplicado no Brasil. Dessa forma, utiliza-se, no Brasil, o Pronunciamento n. 04 do CPC, Ativo Intangível que, segundo o próprio CPC, é correlacionado com a IAS 38. 
Dentre o trabalho da CVM (2008), mencionam-se os seguintes itens:

- Introdução do método da compra para combinações de negócios: resultará na obrigatoriedade de reconhecimento de ativos intangíveis em separado do goodwill. Atualmente, a diferença entre o valor pago e o valor patrimonial é usualmente aglutinada na conta "ágio", apesar de a normatização brasileira não adotar essa postura há 30 anos.

- Alteração da contabilização de ativos intangíveis gerados internamente: fica proibido o reconhecimento de gastos pré-operacionais e de reorganização como intangíveis, assim como aqueles ocorridos durante a fase de pesquisa. Já para a fase de desenvolvimento, a empresa deverá atender aos seis itens estipulados na IAS 38 para que sejam reconhecidos como ativo.

- Reconhecimento do ativo intangível: o item ou grupo de itens deve passar por julgamentos sobre sua identificação em separado, sobre controle e sobre seu potencial de geração de benefícios econômicos futuros. Além disso, sua mensuração exigirá uma profunda discussão sobre os métodos existentes e as razões para a escolha de um determinado método. A CVM (2008) menciona que é provável que as empresas tomem por base operações semelhantes no exterior em países que já apliquem as normas do IASB.

- Vida útil dos ativos intangíveis: indefinida. Para tais casos, a amortização fica proibida. Nesse sentido, haverá necessidade de alteração da Norma Brasileira. O goodwill, por exemplo, não mais será amortizado em até 10 anos, e sim testado anualmente para efeitos de redução em seu valor recuperável (impairment).

- Mensuração: em termos de mensuração, a introdução da Lei 11.638/07 veio proibir as reavaliações de ativos, consistindo em um ponto de diferença entre o modelo brasileiro e o internacional, que permite tal pratica. Sobre esse caso, a CVM opina que deve ser realizada uma consulta ao IASB e ao CPC para avaliar seus respectivos entendimentos sobre o assunto. 
Concluindo, a introdução integral da IAS 38, por meio do CPC 4 - Ativo Intangível, no Brasil, resultará em novas orientações sobre um tema até então pouco explorado pelo mercado e pela academia. Devido à ausência de disciplina normativa que trate, atualmente, do tópico de ativos intangíveis, bem como à consideração de que seja inegável o grau de qualidade que passa a ter a informação contábil com a disciplina dos intangíveis, é recomendável que o Brasil adote, em sua plenitude, a IAS 38. (ERNST YOUNG; FIPECAFI, 2009).

\subsubsection{Divulgação do ativo intangível}

A entidade deve divulgar os seguintes aspectos para cada classe de ativos intangíveis, distinguindo entre os ativos intangíveis gerados internamento e outros ativos intangíveis:

- Se a vida útil é indefinida ou definida e, se for definida, a vida útil ou a taxa de amortização usada;

- Os métodos de amortização usados para ativos intangíveis com vida útil definida;

- $\quad$ O valor contábil bruto e qualquer amortização acumulada (agregada com as perdas de valor acumuladas) no começo e fim do período;

- $\quad$ Os itens de cada linha da demonstração de resultados em que qualquer amortização de ativos intangíveis esteja incluída;

- Uma reconciliação do valor contábil no começo e fim do período.

Além dos dois itens acima, a entidade detentora de Ativos Intangíveis, também, deve divulgar os seguintes itens, segundo o Pronunciamento CPC n. 04:

- Em relação a ativos intangíveis avaliados como tendo uma vida útil indefinida, o seu valor contábil e os motivos que fundamentam essa avaliação, descrevendo os fatores mais importantes que levaram a essa definição; 
- A descrição, valor contábil e o prazo de amortização remanescente de qualquer ativo intangível individual importante para as demonstrações financeiras da entidade;

- $\quad$ Em relação a ativos intangíveis adquiridos por meio de subvenção governamental e inicialmente reconhecidos ao valor justo;

- A existência e os valores contábeis de ativos intangíveis cuja titularidade é restrita e os valores contábeis de ativos intangíveis oferecidos como garantia de obrigações;

- $\quad$ O valor dos compromissos contratuais advindos da aquisição de ativos intangíveis.

\section{$2.4 \quad$ Goodwill}

O goodwill tem sua aparição vinculada a diversos elementos segundo o tempo em que aparecia, passando sua origem no século XVI até chegar à personalidade dos proprietários, processos industriais, conforme explica Antunes (2004, p. 109) em sua tese de doutorado.

O goodwill pode ser considerado como um ativo intangível. Tal assertiva é apoiada por vários estudos acadêmicos como o de Monobe (1986), que afirma que o goodwill se classifica como um ativo intangível especial, distinto dos demais integrantes de seus grupos. Deve ser mencionado que o goodwill é tratado pelo IASB dentro da IFRS 3, Business Combinations, e não pela IAS 38 .

O IASB, por meio da IFRS 3, define o goodwill como: "O goodwill é o resultado de benefícios econômicos futuros decorrentes de ativos que não poderão ser identificados e reconhecidos separadamente."

Um exemplo clássico de tal afirmação é o dado por Ernst \& Young e Fipecafi (2009, p. 325), em que se menciona que os benefícios econômicos futuros poderão resultar da sinergia entre os ativos identificáveis adquiridos ou de ativos que, individualmente, não se qualifiquem para reconhecimento nas demonstrações financeiras, mas que o adquirente se dispôs a adquirir numa combinação de negócios. 
Outra definição de goodwill é dada por Santiago Júnior e Santiago (2007). Para os autores:

o valor dos resultados financeiros que uma empresa apresenta em seus relatórios contábeis apresenta diferença quando comparada ao valor de mercado dela, em razão, principalmente, do que na linguagem contábil se chama de goodwill.

Niyama (2005) explica que o ativo intangível pode ser claramente identificável do goodwill se o ativo for separável. Um ativo é separável se a entidade puder alugar, vender, trocar ou distribuir os benefícios econômicos futuros atribuíveis para o ativo, sem prejuízo de benefícios econômicos futuros de outros ativos, utilizados na mesma atividade.

Martins (1972, p. 55) elucida "que se procurou em vão, um termo em português que pudesse ter um significado suficientemente preciso para ser usado como perfeita tradução da palavra inglesa goodwill'. Continua o autor mencionando que o termo goodwill já foi consagrado entre os leitores e especialistas da área contábil.

Por último, Martins informa que não se deve tratar o goodwill como sinônimo de fundo de comércio, visto que são distintos seus significados e que fundo de comércio como sinônimo de goodwill pode ser considerado como uma "idéia infeliz".

Os estudiosos, entretanto, consagraram o goodwill na sua versão original, pois não há um termo técnico correspondente adequado na língua portuguesa, assim como "feedback" e outros. Todavia, cabe destacar que o termo goodwill possui uma denotação mais abrangente.

Para o real entendimento do goodwill, pode-se afirmar que ele tem conceito residual. A evolução conceitual pela qual passou o goodwill não retirou seu caráter residual no que diz respeito ao seu valor, decorrente, sobremaneira, da forma de sua apuração. (MONOBE, 1986).

Pode-se afirmar que todos esses fatores em conjunto vieram sendo apontados como os responsáveis pela geração do lucro da empresa a longo prazo e não reconhecidos pela Contabilidade, da mesma forma como se vem atribuindo, hoje, aos elementos do Capital Intelectual. (ANTUNES, 2004). 
Outro conceito importante concernente ao ativo intangível é o de sinergia. Mesmo ocorrendo a identificação e mensuração de todos os ativos, sejam eles tangíveis ou intangíveis, seus valores econômicos ou de uso sofreriam um efeito sinergético resultante dessa operação.

Pode-se entender como efeito sinergético a resultante da combinação dos ativos no processo operacional. O termo sinergia tem sua origem no termo grego syn - (com) e ergos (trabalho) que significa, literalmente, um somatório de trabalhos ou atividades desempenhadas para fim específico.

Há o efeito de sinergia quando duas ou mais causas produzem, atuando conjuntamente, um efeito maior que a soma dos efeitos que produziram atuando individualmente, quando existe sinergia o todo é maior que a soma das partes. Adaptando-se o conceito de sinergia à avaliação de ativos: ocorrendo sinergia positiva, o valor da empresa seria sempre maior que a soma dos valores econômicos de todos os ativos utilizados, sem exceção. (Ibid., p. 80).

Para que o Ativo Intangível possa ser identificado é necessário que atenda aos seguintes critérios de identificação:

- For separável da entidade e vendido, transferido, licenciado, alugado ou permutado, tanto individualmente como em conjunto com um contrato, ativo ou passivo relacionado $\mathrm{ou}$

- Resultar de direitos contratuais ou de outros direitos legais, independentemente de os direitos poderem ser transferidos ou separados da entidade ou de outros direitos e obrigações.

Martins (1972, p. 60) comenta que a Contabilidade, ao tratar o goodwill ao longo do tempo, acabou por criar uma série de conceitos para sua definição e mensuração. Conceitos esses diversos entre si e que têm sofrido mutações no correr dos anos. São os principais conceitos:

- Grupo que tem por fundamento a definição do goodwill como sendo o valor atual dos super-lucros; 
- Aquele que o considera como subavaliação dos Ativos ou falta de registro de alguns deles;

- Aqueles que conceituam o goodwill como "master valuation account";

- $\quad$ Super-lucro: dentro de uma atividade econômica qualquer, na qual diversas empresas operam e uma delas ou várias se destacam sobre as demais, auferem maior lucro sobre o investimento, diz-se, então, que elas estão auferindo "super-lucro".

\subsubsection{Classificação do goodwill}

Existe uma série de classificações atribuídas ao goodwill. Uma das clássicas e utilizadas é a de Martins (1972, p. 73), que explica, minuciosamente, o motivo de tal classificação. Destaque-se que o estudo de Martins foi baseado na obra de Paton e Paton Jr. (1958). São elas:

- Goodwill comercial: aquele que aparece em função dos seguintes fatores:

a) serviços colaterais, como equipe cortês de vendedores, entre convenientes, facilidades de crédito, dependências apropriadas para serviço de manutenção etc.;

b) qualidade do produto em relação ao produto e

c) atitude e hábito do consumidor como fruto de nome comercial e marca tornados proeminentes em função da propaganda persistente.

- Goodwill industrial: o que surge em função dos altos salários, baixo turnover de empregados, oportunidades internas satisfatórias para acesso às posições hierárquicas superiores, serviço médico, sistema de segurança adequado etc., desde que tais fatores contribuam para a boa imagem da empresa e também para a redução do custo unitário de produção. Dessa forma, um valor é adicionado à empresa: o goodwill.

- Goodwill financeiro: aquele derivado da atitude de investidores, fontes de financiamento e de crédito (para capital em dinheiro, bens ou serviços). Existindo essas condições em caráter bastante favorável, tem a firma sólida situação para cumprir suas 
obrigações e manter sua imagem, ou, então, obter recursos financeiros que lhe permitam aquisições de matéria-prima ou mercadoria em melhores termos e preços.

- Goodwill político: é aquele obtido em função de boas relações com o Governo. Esse fator tem crescido em importância. Reconhecem, também, a dificuldade de se efetuar essa própria classificação e admitem a quase impossibilidade prática de se atribuir o todo do goodwill a cada um dos fatores que o provocam.

- Goodwill comercial: aquele criado independentemente das pessoas proprietárias ou administradoras da empresa, ou seja, o criado em função, única e exclusivamente, da firma como um todo. Abrangeria parte dos quatro grupos citados anteriormente, englobando de cada um deles o que não recebeu influência pessoal dos proprietários ou dos gerentes da entidade.

- Goodwill pessoal: exatamente aquele que surge em função de uma ou várias pessoas que integram a empresa, sendo elas proprietárias ou administradoras. Corresponde, mais ou menos, ao complemento do Goodwill Comercial.

- Goodwill profissional: o desenvolvido por uma classe profissional (normalmente considerada como classe de profissionais liberais) que acaba por criar uma imagem que a distingue o suficiente dentro da sociedade a fim de lhe propiciar condições de alta remuneração. Podem ser citados os médicos, advogados, contadores (em alguns países) etc..

- Goodwill evanescente: é o goodwill que tem uma vida muito limitada, pois as circunstâncias que o suportam são de curta duração, como é o caso característico de certos produtos que a moda cria; podem ser de qualquer natureza: jogos, vestuários, lugares públicos (boates etc.).

- Goodwill de nome ou marca comercial: independe do produto, pois concorrentes que o fabricam com as mesmas características, e que só pode ser ocasionado pela imagem do nome da empresa que o produz ou da marca sob o qual é comercializado. 
Martins (1972, p. 75) menciona que os autores Catlett e Olson citam os seguintes fatores como sendo responsáveis pelo surgimento do goodwill dentro da entidade como importante ativo a ser considerado. São eles:

- Administrador;

- $\quad$ Organização ou gerente de vendas proeminente;

- $\quad$ Fraqueza na administração do competidor;

- $\quad$ Propaganda eficaz;

- $\quad$ Processos secretos de fabricação;

- Boas relações com empregados;

- Crédito proeminente como resultado de sólida reputação;

- $\quad$ Excelente treinamento para os empregados;

- Alta posição perante a sociedade conseguida por meio de ações filantrópicas e participação em atividades cívicas por parte dos administradores da empresa;

- Desenvolvimento desfavorável nas operações do competidor;

- $\quad$ Associações favoráveis em outra empresa;

- $\quad$ Localização estratégica;

- Descoberta de talentos ou recursos;

- $\quad$ Condições favoráveis com relação aos impostos; 
- Legislação favorável.

Martins (1972, p. 78) explica que:

ainda que "o goodwill tem sido genericamente aceito como o fruto da existência de diversos fatores que a Contabilidade não aceita formalmente como elementos do Ativo, quer sejam eles a organização interna da empresa, o bom relacionamento com os empregados, a condição monopolística, a localização da entidade ou outros quaisquer.

Desses fatores um dos mais comentados e frequentemente encontrado na prática é o elemento humano.

Monobe (1986, p. 44) explica que, embora alguns autores relutem ou até lhe neguem a condição real de ativo em função de suas características peculiares, o goodwill enquadra-se, segundo a maioria, na classificação de ativo intangível. Um intangível ainda desprezado pela Contabilidade, a não ser que uma transação o traga à tona, tornando inevitável o seu reconhecimento e registro.

Existe, porém, a ocorrência de um valor negativo referente ao goodwill, nos casos em que o valor atual dos lucros futuros da empresa for menor que o valor econômico de seus ativos. Tratar-se-ia do chamado goodwill negativo ou "badwill", não muito enfocado em estudos acadêmicos, segundo Monobe (1986).

Nessa situação, a empresa valeria mais pelos ativos que pelas perspectivas de lucros futuros. Aos seus proprietários seria mais vantajoso liquidar os ativos e vender a empresa, enquanto para os compradores em potencial isso poderia significar um fator ponderável na aquisição, já que as condições desfavoráveis determinantes da situação da empresa podem ser sanáveis por uma nova administração.

Na moderna conceituação de goodwill, em que o seu valor corresponde à diferença entre o valor atual da empresa como um todo, em termos de capacidade de geração de lucros futuros, e o valor econômico dos seus ativos, pode-se afirmar a dependência de:

- $\quad$ Estimativa dos lucros futuros esperados da empresa; 
- Identificação e mensuração do valor econômico dos seus ativos e, finalmente,

- Taxa de desconto ideal para a apuração do valor atual.

Parte-se da premissa de que a Contabilidade precisa registrar todos os recursos que contribuem para o desempenho de uma entidade, não se restringindo somente aos de fácil mensuração, pois, assim, não procedendo, muitos fatores importantes acabam sendo desconsiderados pelos registros contábeis, provocando distorções nas suas análises.

A mensuração e a contabilização de recursos humanos têm merecidos estudos e teses, inclusive no Brasil, ficando demonstrada a necessidade de uma definição em relação à forma de disclosure daqueles que constituem, possivelmente, um dos fatores de lucro mais importantes de uma empresa.

\subsubsection{Reconhecimento do goodwill}

O estudo de Ernst \& Young e Fipecafi (2009, p. 334) evidencia que o goodwill é a única exceção ao critério de identificação contábil, pois o mesmo é definido como o montante excedente sobre o patrimônio líquido a valor justo dos ativos líquidos identificáveis.

O principal exemplo de um ativo intangível que não possui usos alternativos, não é separável e cujos benefícios são muito incertos, é o próprio goodwill. Em princípio, poder-se-ia reconhecer o goodwill a qualquer momento, comprando o valor de mercado de uma empresa ao valor de seus ativos líquidos.

Monobe (1986) afirma em sua tese que:

o patrimônio líquido poderia ser reavaliado a mercado usando-se uma conta de reavaliação, e uma conta de goodwill poderia ser incluída entre os ativos. Ao que parece, porém, pouco seria conseguido com esse tratamento. O goodwill representa vantagens que não são especificamente identificáveis; o que falta, portanto, é um método lógico de vinculação desses custos a qualquer receita em período futuros.

O processo citado acima, todavia, não é de fácil realização. Utilizando-se a afirmação de Monobe, conclui-se a real dificuldade no processo de reconhecimento do goodwill. Cabe a 
necessidade de que haja estudos sobre o desenvolvimento de formas específicas e menos subjetivas para o reconhecimento do goodwill.

Quanto ao reconhecimento do goodwill, o CPC informa que o ágio derivado da expectativa de rentabilidade futura (goodwill) gerado internamente não deve ser reconhecido como ativo. Segue descrição detalhada do parágrafo 48 do Pronunciamento CPC que trata do Ativo Intangível:

[...] em alguns casos incorre-se em gastos para gerar benefícios econômicos futuros, mas que não resultam na criação de ativo intangível que se enquadre nos critérios de reconhecimento. Esses gastos costumam ser descritos como contribuições para o ágio derivado da expectativa de rentabilidade futura (goodwill) gerado internamente, o qual não é reconhecido como ativo porque não é um recurso identificável (ou seja, não é separável nem advém de direitos contratuais ou outros direitos legais) controlado pela entidade que pode ser mensurado com segurança ao custo.

As diferenças entre valor de mercado da entidade e o valor contábil de seu patrimônio líquido, a qualquer momento, podem incluir uma série de fatores que afetem o valor da entidade. No entanto, essas diferenças não representam o custo dos ativos intangíveis controlados pela entidade.

Dadas as características acima, pode-se caracterizar o Capital Intelectual como derivado do goodwill. Tal assertiva pode ser corroborada consultando a obra de Antunes (2000, p. 88), na qual a autora afirma que "Goodwill e o Capital Intelectual fazem parte de um mesmo fenômeno que identificam um valor a mais para uma organização quando não contabilizados pela contabilidade financeira”. Explica, ainda, que, de certa forma, a identificação de alguns desses elementos componentes do Capital Intelectual pode diminuir a quantidade do goodwill adquirido.

\subsubsection{Contabilização do goodwill}

Segundo Niyama (2005, p. 65) a principal questão sob a perspectiva contábil envolvendo o goodwill é se:

- Deve ser reconhecido como Ativo (e amortizado segundo a expectativa de benefícios futuros) ou 
- Deve ser imediatamente baixado contra o Patrimônio Líquido (ou resultado do período vigente).

Ademais, o autor comenta e critica em sua obra que os principais estudiosos sobre o tema destacam quatro alternativas para a contabilização do goodwill. São elas:

- Capitalização como ativo, sem amortização: os defensores desse método, segundo Niyama, argumentam que o goodwill adquirido deve ser capitalizado na premissa de obtenção de benefícios econômicos futuros e, considerando-se que, num empreendimento de sucesso, não há declínio no valor correspondente ao goodwill, bem como em contexto de continuidade (going concern), não é necessária a sua amortização. Os oponentes a essa ideia argumentam que o goodwill tem vida útil e, portanto, deve ser sujeito à amortização. Niyama acredita que a argumentação é frágil pelo simples fato de que nenhum ativo mantém inalterada, ao longo do tempo, sua potencialidade de gerar benefícios futuros.

- Capitalização como ativo, com diferentes prazos para a amortização em função do prazo útil de obtenção dos benefícios futuros. Os defensores desse método argumentam que um goodwill não é diferente dos outros ativos, já que é consumido (ou é necessário) no processo de obtenção da receita e, conforme manda o Princípio da Competência, deve ser confrontado no período contábil correspondente. Quanto ao prazo, semelhantemente a um ativo imobilizado, envolve certa dose de arbitrariedade e subjetivismo.

- Baixa Imediata contra o Patrimônio Líquido: argumenta-se que o goodwill não deve ser capitalizado como ativo na medida em que não pode ser identificado e segregado de forma objetiva e que ele existe em razão da possível valorização do empreendimento (ou da companhia) como um todo. Não é, portanto, comparável a outro ativo passível de identificação e confrontação com a receita, em obediência ao Princípio da Competência.

- Além disso, os benefícios econômicos futuros esperados podem não guardar, necessariamente, nenhum tipo de vinculação com os valores pagos no passado, a título de goodwill, para serem confrontados. Também, essa é uma das razões para a baixa 
imediata contra Reserva de Lucros Acumulados (e não resultado), já que somente o exercício corrente seria penalizado se reconhecido no resultado.

- Baixa Imediata contra o Resultado do Exercício: trata-se de uma variante do terceiro método, já que se defende a não capitalização do goodwill como "ativo", mas, em vez da baixa imediata contra o Patrimônio Líquido, defende a baixa em resultado. Os resultados desse método argumentam que a baixa deve ser imediata contra o resultado do Período, em "Itens Extraordinários", dentro da visão de conceito limpo e não abrangente (All-inclusive).

De acordo com a IAS 38, o goodwill adquirido deve ser capitalizado como ativo e amortizado durante o prazo de vida útil, usualmente, não superior a 20 anos. Além disso, a norma explana sobre a necessidade da realização anual do teste de recuperabilidade ou Impairment (Impairment Test), caso queira adotar o prazo superior a 20 anos, o que reduz, na prática, a adoção de tal alternativa.

Por outro lado, as normas internacionais de Contabilidade não permitem a capitalização do goodwill gerado internamente, nem de qualquer outro ativo intangível.

\subsection{Conhecimento como recurso competitivo}

Após discutida a literatura sobre a Contabilidade, o processo contábil e o Ativo, cabe verificar como o conhecimento contribui para as entidades, conhecimento esse tratado como um recurso competitivo.

O conhecimento pode ser desenvolvido internamente à empresa, pode ser coletado externamente ou pode ser desenvolvido por relações de parceria ou alianças estratégicas com empresas, universidades ou instituições externas à organização. (FLEURY; FLEURY, 1997).

Nesse contexto, por administração do conhecimento entende-se o processo de identificar, desenvolver, disseminar e atualizar o conhecimento estrategicamente relevante para a 
empresa, seja a partir de esforços internos à organização, seja a partir de processos que extrapolem suas fronteiras.

Ênfase em conhecimento é dada por Antunes (2000, p. 47), em que a autora cita que "o recurso essencial para as empresas é o conhecimento e quem o possui são as pessoas". Dessa forma, pode-se inferir que o conhecimento adquirido ao longo do tempo pelos colaboradores é de vital importância para que as entidades possam dar prosseguimento ao seu negócio.

Fleury e Fleury (1997) explicam que a aprendizagem é um processo de mudança, resultante de prática ou experiência anterior, que pode vir ou não a manifestar-se em uma mudança perceptível de comportamento.

Duas vertentes teóricas sustentam os principais modelos de aprendizagem: o modelo behaviorista e o modelo cognitivo. Os principais traços relevantes de cada um desses modelos são os seguintes:

- Modelo Behaviorista: seu foco principal é o comportamento, pois esse é observável e mensurável; partindo do princípio de que a análise do comportamento implica o estudo das relações entre eventos estimuladores, respostas, consequências; planejar o processo de aprendizagem implica definir todo o processo, em termos passíveis de observação, mensuração e réplica científica;

- Modelo cognitivo: pretende ser um modelo mais abrangente do que o behaviorista, explicando melhor os fenômenos mais complexos, como a aprendizagem de conceitos e a solução de problemas. Procura utilizar dados objetivos, comportamentais e dados subjetivos; leva em consideração as crenças e percepções dos indivíduos que influenciam seu processo de apreensão da realidade.

Fleury e Fleury (1997, p. 20) explicam que a aprendizagem organizacional incorpora, sem, entretanto polarizar, o debate entre os modelos behaviorista e cognitivista, no que diz respeito ao fato do processo de aprendizagem implicar ou não mudanças comportamentais visíveis, mensuráveis. 
Os autores afirmam que as organizações devem desenvolver cinco disciplinas fundamentais para o processo de inovação e aprendizagem:

- Domínio pessoal: adquirido pelo autoconhecimento; as pessoas aprendem a clarificar e aprofundar seus próprios objetivos, a concentrar esforços e a ver a realidade de forma objetiva;

- Modelos mentais: são ideias profundamente enraizadas, generalizações e mesmo imagens que influenciam o modo como as pessoas veem o mundo e as suas atitudes;

- Visões partilhadas: quando um objetivo é percebido como concreto e legítimo, as pessoas dedicam-se e aprendem não como uma obrigação, mas por vontade própria, construindo visões partilhadas. Muitos líderes têm objetivos pessoais, que nunca chegam a ser partilhados pela organização como um todo; a organização funciona muito mais devido ao carisma do líder ou às crises que unem a todos temporariamente;

- Aprendizagem em grupo: em grupos em que as habilidades coletivas são maiores que as habilidades individuais, desenvolve-se a capacidade para ação coordenada. A aprendizagem em grupo começa com o diálogo; em outras palavras, com a capacidade dos membros do grupo em propor suas ideias e participar da elaboração de uma lógica comum;

- Pensamento sistêmico: constitui um modelo conceitual, composto de conhecimentos e instrumentos, desenvolvidos ao longo dos últimos 50 anos, que visam melhorar o processo de aprendizagem como um todo e apontar futuras direções para aperfeiçoamento.

Nonaka e Takeuchi (1997, p. 24) afirmam que o conhecimento individual está baseado no conjunto de crenças na verdade e que isso não constitui o verdadeiro conhecimento. É importante destacar que o conhecimento e seu aprendizado não são inerentes ao ser individual. Segundo Fleury e Oliveira (2001, p. 62), o conhecimento fundamenta-se não só no indivíduo, mas está distribuído entre um grupo de pessoas que trabalham juntas ou desenvolvem alguma atividade em conjunto. 


\subsubsection{A sociedade do conhecimento}

A economia sempre migrou de um estado para outro, conforme o passar do tempo. Segundo Crawford (1994, p. 29), a economia ascendeu da fase industrial para economia do conhecimento, na qual ocorreu uma série de mudanças. Entre essas mudanças, destacam-se as seguintes:

- A automação do trabalho: atividades intensivas de manufatura, bem como um incremento de automação de uma vasta gama de atividades de serviços;

- Um crescimento generalizado na indústria de serviços, particularmente na saúde, educação, produção de software e entretenimento;

- A redução no tamanho das grandes empresas tanto na manufatura quanto de serviços, devido ao maior estímulo ao espírito empreendedor;

- Uma mudança na força de trabalho, com um crescimento acentuado de participação de mulheres (que são ao mesmo tempo o segmento de crescimento mais rápido da força de trabalho e também o que progride mais aceleradamente em termos de status econômico);

- Transformações demográficas substanciais causadas pela queda na taxa de nascimento e uma população mais velha;

- Substituição do centro geográfico da economia, antes centrada em matérias-primas e bens de capital para se concentrar em informações e conhecimentos, particularmente pesquisa e educação.

Ademais, Crawford (1994) cita que há alguns pontos-chaves que diferenciam a economia do conhecimento de suas predecessoras. São eles:

- O conhecimento científico básico e a pesquisa tornaram-se a força propulsora da economia, gerando nova tecnologia, promovendo oportunidades para inovações e criando novas indústrias; 
- A educação tem um papel fundamental quando os serviços de informações são o maior segmento da economia;

- $\quad$ A participação das mulheres na força de trabalho aumenta sensivelmente e essas buscam igualdade de salário com os homens;

- $\quad$ As ideologias políticas decaem e as forças econômicas e políticas se dispersam;

- Novas tecnologias de administração de organizações são desenvolvidas, utilizando-se tecnologia intensiva e enfatizando os recursos humanos.

A característica mais marcante da economia do conhecimento é o surgimento do termo capital humano, ou seja, pessoas educadas e habilitadas, como força dominante da economia para exercer determinadas atividades não comuns nas fases econômicas anteriores, como a industrial, por exemplo.

Embora a quantidade de capital físico e financeiro na sociedade industrial fosse um fator crítico para seu sucesso, na economia do conhecimento a importância relativa do capital físico diminuiu à medida que elementos-chaves como computadores se tornam baratos e a quantidade e qualidade do capital humano crescem em importância.

Crawford (1994, p. 46) explica que:

[...] o mundo entrou num período de mudanças similar à primeira fase da Revolução Industrial. Baseada fundamentalmente em uma nova infra-estrutura científica, a tecnologia de uma economia do conhecimento é radicalmente diferente daquela da economia industrial.

A tecnologia industrial movimentava a força física e criava produtos físicos e a tecnologia do conhecimento cria e movimenta informações ou, alternativamente, reduz o volume físico dos produtos, propiciando maior conforto aos seus usuários.

A tecnologia empregada pela Revolução Industrial era mecânica em sua natureza e baseada na Lei de Newton, desenvolvida no século XVII. A tecnologia da economia do conhecimento baseia-se numa grande quantidade de progressos científicos do século XX, particularmente nos progressos da física, pesquisas biotecnológicas e afins. 
As pessoas estão familiarizadas com a economia do conhecimento. Pensa-se nela como alta tecnologia: computadores, comunicação avançada, robôs, ciências dos materiais, biotecnologia, lasers e energias.

Essa tecnologia afetou de forma dramática a produtividade ao permitir que as indústrias fabricassem produtos de alta qualidade com poucas horas de trabalho, pouca energia e material e também ao permitir que o setor de serviços operasse mais eficientemente, com menor número de pessoas e menor quantidade de recursos materiais e energéticos.

As mudanças demográficas, dos padrões sociais e da produção econômica, causadas pela nova tecnologia e pelos novos métodos organizacionais, estão transformando, radicalmente, os mercados e a força de trabalho. Uma tendência é a de que, à medida que os mercados de bens de maior consumo ficam saturados e a receita dos consumidores é gasta com serviços, há maior crescimento do mercado de serviços em detrimento do mercado de bens. (Id., 1994).

Ademais, numa economia do conhecimento, a demanda por serviços cresce a uma taxa mais elevada do que a demanda por bens. Os bens tendem a ser usados para satisfazer às necessidades físicas básicas: alimentação, roupa, moradia e automóveis são as despesas básicas dos consumidores com bens. Quando a maior parte da população já satisfez suas necessidades físicas básicas, a demanda por bens estabiliza e a demanda pelos serviços cresce.

Para Fleury e Oliveira (2001, p. 212), é relativamente difícil encontrar um denominador comum ou mesmo estabelecer limites para a forma como os termos conhecimento, competência, aprendizado e habilidade, criatividade, capital intelectual, capital humano, tecnologia, capacidade inovadora, ativos intangíveis e inteligência empresaria, entre outros, são utilizados na Sociedade do Conhecimento.

É importante que se compreenda que o recurso conhecimento e sua gestão no ambiente empresarial têm tido diferentes focos. Os autores citam alguns desses focos provenientes da atual Sociedade do Conhecimento:

- Aprendizado individual e organizacional (cultura organizacional);

- $\quad$ Relações entre pessoas, diferentes áreas da empresa, diferentes empresas e o ambiente; 
- Desenvolvimento de competências individuais e organizacionais;

- Mapeamento, codificação e compartilhamento do conhecimento organizacional;

- $\quad$ Conectividade entre as pessoas;

- Alavancagem dos avanços em informática e em telecomunicações;

- Mensuração do Capital Intelectual da empresa.

Nesse contexto, o desafio contemporâneo de se produzir mais e melhor vai sendo suplantado pelo desafio permanente de criar novos produtos, serviços, processos e sistemas gerenciais. Entretanto, a velocidade das transformações e a complexidade crescente dos desafios não permitem mais concentrar esses esforços em alguns poucos indivíduos ou áreas das organizações.

Finalmente, essas novas indústrias diferem da indústria "moderna" tradicional porque empregarão, predominantemente, empregados com conhecimento e não operários manuais. A programação de computadores, por exemplo, com suas enormes oportunidades de emprego, é um trabalho semiqualificado. (Id., 2001).

Antunes (2000, p. 13) afirma que:

[...] aceitando-se o conhecimento como o novo fator de produção, que vem se aliar aos já existentes - terra, trabalho e capital - ou mesmo, como substituto definitivo, instala-se um período de transformações, cujos efeitos estão se espalhando mundialmente, alterando os sistemas político, social e econômico dos países que se encontram em tal estágio de desenvolvimento.

Embora as mudanças na sociedade atual sejam profundas e perceptíveis, são contínuas, porém nem sempre uniformes. Isso é resultado da forma gradativa e diferenciada de acordo com o grau de evolução econômica em que o país se encontra. (Id., 2000).

Outro autor que compara a utilização do uso do conhecimento aplicado com demais recursos econômicos é Quinn (1992). Para o autor, o poder econômico e produtivo de uma organização 
moderna está mais explicitado nos itens ligados ao Capital Intelectual do que aos ativos tangíveis tradicionais.

STEWART (2001, p. 6) comenta em sua obra que o conhecimento e a informação fazem parte de cada produto ou serviço que a sociedade utiliza na atualidade, ou seja, que estão embutidos no processo de produção ou na prestação de serviços.

\subsection{Capital Intelectual}

\subsubsection{Introdução}

O Capital Intelectual pode ser uma teoria, sendo recentemente veiculada de uma forma mais organizada. Na prática, sempre se esgueirou no valor resultante da diferença entre o valor de mercado de uma empresa e seu valor contábil. (EDVINSSON; MALONE 1998).

Porém, até recentemente, acreditava-se que essa diferença fosse um fator inteiramente subjetivo, movido por rumores, informações privilegiadas a respeito de lançamento de produtos e uma sensibilidade apurada em relação às perspectivas de uma empresa, que jamais poderia ser medido empiricamente.

Para Antunes (2004, p. 49): “o conceito do Capital Intelectual está diretamente relacionado aos elementos intangíveis resultantes das atividades e práticas desenvolvidas pelas organizações para se adaptarem e atuarem na realidade atual.”

Em sua conceituação abrangente, o Capital Intelectual apresenta-se para identificar, classificar, mensurar e gerenciar os elementos que atuam na gestão das organizações da Sociedade do Conhecimento.

Pacheco (2005, p. 29) afirma que o termo Capital Intelectual foi cunhado, ou seja, foi criado por Thomaz Stewart (2001) em seu livro intitulado, originalmente, como "The Wealth of Knowlegde". 
Niyama (2005), por sua vez, explica que se costuma afirmar que o goodwill é um ativo intangível que, presumivelmente, permite à empresa auferir ganhos para os quais os ativos tangíveis, isoladamente, não teriam essa capacidade. Incluem-se, portanto, itens não quantificáveis, tais como uma boa reputação e imagem de credibilidade, competência da administração, quadro de funcionários, cadastro de clientes etc..

Crawford (1994, p. 38) afirma que

[...] na Sociedade do Conhecimento, a educação é universal e os níveis de educação crescem para as novas áreas de conhecimentos que requerem mais treinamento e educação atualizada para sua aplicação. Além disso, informa que os profissionais universitários e especializados tornam-se o maior grupo empregado.

Essa afirmação vem a corroborar a ideia de Quinn (1992), em que é realizada uma analogia entre o conhecimento utilizado com outros recursos econômicos. Quinn menciona que os ativos componentes do Capital Intelectual são mais importantes na obtenção de resultados e riquezas do que os ativos tangíveis. Por último, menciona que $75 \%$ do valor agregado de um determinado produto seja proveniente do conhecimento embutido a ele durante seu processo de fabricação.

Como resultado de sua pesquisa, Crawford (1994, p. 159) supõe que $70 \%$ dos recursos de uma empresa média se constituem de seu capital humano, não é de se surpreender que uma melhor administração desses recursos aperfeiçoe o desempenho financeiro da empresa. Além disso, a identificação de empresas que, efetivamente, valorizam seus recursos humanos pode ajudar a projetar um desempenho superior no futuro.

O trabalho com base no conhecimento não é facilmente definido em termos quantitativos, podendo, de fato, não se prestar a quantificação alguma, sendo que o conhecimento, também, não possui fácil mensuração, mas agrega mais riquezas à entidade em que é utilizado. (DRUCKER, 1972, p. 324).

A sociedade do conhecimento necessita de pessoas estudadas, ou seja, detentoras de conhecimento, para entender a formação que produzem, mas, igualmente, requer tecnologia para produzir essas informações. (CRAWFORD, 1994). 


\subsubsection{Definição}

Uma das definições mais utilizadas em estudo sobre o Capital Intelectual é a de Edvinsson e Malone (1998). Antes de definir o termo, os autores utilizam metáfora para facilitar a compreensão do Capital Intelectual. Essa metáfora equipara uma empresa com um organismo vivo, uma árvore especificamente. Dessa forma, o que é descrito em organogramas, relatórios anuais, demonstrações financeiras trimestrais, brochuras explicativas e outros documentos (reports) constitui o tronco, os galhos e as folhas, ou seja, a parte visível.

Além disso, os autores afirmam que presumir, porém, que essa é a árvore inteira, por representar tudo que seja imediatamente visível, é um erro, pois outras partes constituintes da árvore se encontram abaixo da superfície, como as raízes.

A síntese da analogia de Edvinsson e Malone (1998) pode, assim, ser resumida:

[...] compreender o que acontece nas raízes é uma maneira muito mais eficaz de reconhecer quão saudável a árvore em questão será nos anos vindouros. $\mathrm{O}$ apodrecimento ou o parasita, que agora começam a atingi-la a nove metros abaixo da superfície, pode muito bem matar a árvore que hoje aparente gozar de excelente saúde.

Como definição propriamente dita, Edvinsson e Malone (1998, p. 40) explicam que o Capital Intelectual é a posse de conhecimento, experiência aplicada, tecnologia organizacional, relacionamentos com clientes e habilidades profissionais que proporcionam à empresa uma vantagem competitiva no mercado.

Para Lev (2001), o Capital Intelectual pode ser definido da seguinte forma: "o Capital Intelectual nada mais é do que um ativo intangível que fornece benefícios econômicos futuros para a entidade que o possui por meio de um gerenciamento adequado."

Antunes (2004, p. 53) comenta que a definição do Capital Intelectual está sendo evidenciada por meio da classificação dos elementos identificados que o compõem. Assim sendo, os elementos do Capital Intelectual identificados encontram-se ligados diretamente ao conhecimento e à capacidade de aprendizagem organizacional, à gestão de recursos humanos e à tecnologia da informação. 
Brooking (1996) define o Capital Intelectual como "um conjunto de ativos intangíveis, resultantes das mudanças nas áreas de tecnologia da informação, que trazem benefícios intangíveis para as empresas e que capacitam o funcionamento das mesmas."

Stewart (2001, p. 6) define Capital Intelectual como sendo os ativos do conhecimento, competências, know-how e outros itens utilizados pelas empresas para criação de riquezas.

Além disso, o autor critica os profissionais de Contabilidade pela quantidade excessiva de regras para que os ativos e passivos sejam reconhecidos nas demonstrações contábeis. Para Stewart (2001), as regras são importantes para esse efeito, mas não para o propósito do Capital Intelectual.

Para Stewart, o ativo deve ser considerado como algo que transforma a matéria-prima em algo mais valioso e que os meios tradicionais de reconhecimento não contemplam os ativos intangíveis como o Capital Intelectual.

Edvinsson e Malone (1998) questionam por que as demonstrações contábeis não oferecem mais informações sobre o verdadeiro valor da empresa. Comentam os autores que o modelo tradicional de Contabilidade não tem conseguido acompanhar a revolução que está ocorrendo no mundo dos negócios.

Considerado como Ativo, o Capital Intelectual necessita de gestão para que atinja os objetivos da empresa, entre eles a obtenção de lucro. Para Stewart (2001, p. 77), há quatro passos que possuem forte grau de subjetividade, para que possa ser realizado o gerenciamento do Capital Intelectual. São eles:

- Identificar e avaliar o papel do conhecimento no negócio, elaborando questões como: Quem paga por aquilo que é considerado como conhecimento? Quem realiza esse pagamento? Quanto é desembolsado? Será que quem detiver o conhecimento também criará mais valor?

- Quais são os conhecimentos, capacidades, marcas, propriedades intelectuais, os processos e outros ativos intelectuais que criam valor para a empresa? Qual é o mix entre capital humano, capital estrutural e de clientes? 
- Desenvolver uma estratégia de investimento em ativos intelectuais. Verificar quais estratégias existem para aumentar a intensidade de conhecimento de seu negócio e de que maneira pode ser aumentada a capacidade de alavancar os ativos intelectuais?

- Melhorar a eficiência do trabalho e conhecimento dos colaboradores, buscando aumentar o conhecimento da produtividade do trabalhador.

\subsubsection{Classificações do Capital Intelectual}

Para Brooking (1996), o Capital Intelectual é dividido em quatro partes. São elas: ativos de mercado; ativos humanos; ativos de propriedade intelectual e ativos de infraestrutura. Segue a descrição de cada um desses itens:

- Ativos de mercado: são ativos intangíveis relacionados ao mercado como: marcas, clientes, fornecedores, canais de venda e distribuição etc.;

- Ativos humanos: estão concentrados nos conhecimentos dos colaboradores da entidade, por meio de seu expertise;

- Ativos de propriedade intelectual: ativos que necessitam de proteção legal. Segredos industriais, novos designs, patentes etc. e

- Ativos de infraestrutura: tecnologias, metodologias e processos da empresa, sistemas de informação, banco de dados de clientes, modelos gerenciais etc..

Para Stewart (2001, p. 13), o Capital Intelectual pode ser dividido em três partes: capital humano (as competências e conhecimento das pessoas); capital estrutural (patentes, processos, bases de dados, redes etc.) capital e de clientes (relacionamento com clientes e fornecedores).

Segundo Sveiby (1997), o Capital Intelectual pode ser classificado de três formas, competência individual, estrutura interna e estrutura externa. Essas formas podem, assim, ser explicadas: 
- Competência individual: envolve a capacidade de atuar em uma ampla variedade de situações para criar tanto ativos tangíveis como intangíveis. Comenta o autor que pode haver críticas quanto ao fato de não concordarem com o fato de que a competência de um funcionário se caracteriza como ativo intangível. Todavia, Sveiby diz que a competência individual não pode ser propriedade de uma entidade e, sim, da pessoa que a possui.

- Estrutura interna: a estrutura interna inclui patentes, conceitos, modelos, sistemas de informática e outros sistemas de informações e controles administrativos. Esses itens são criados pelos empregados e são, geralmente, propriedade da organização. Além disso, a cultura organizacional é uma estrutura interna pertencente à entidade.

- Estrutura externa: a estrutura externa inclui relações com clientes e fornecedores. Além disso, possui, também, as marcas e patentes, bem como a reputação da empresa ante a sociedade da qual faz parte. Alguns desses itens podem ser considerados bens jurídicos, mas os investimentos na estrutura externa não podem ser feitos com o mesmo grau de confiança como os investimentos em estrutura interna.

O Capital Intelectual é divido entre capital humano e capital estrutural (que engloba capital de clientes). Segundo Edvinsson e Malone (1998, p. 10), essas definições podem, assim, ser definidas:

- Capital humano: o conhecimento, a experiência, o poder de inovação e a habilidade dos empregados de uma companhia para realizar as tarefas do dia a dia. Inclui, também, os valores, a cultura e a filosofia da empresa. O capital humano não pode ser de propriedade da empresa.

- Os equipamentos de informática, os softwares, os bancos de dados, as patentes, as marcas registradas e todo o resto da capacidade organizacional que apoia a produtividade daqueles empregados, em poucas palavras: tudo o que permanece no escritório quando os empregados retornam para suas casas. O capital estrutural também inclui o capital de clientes, o relacionamento desenvolvido com os principais 
clientes. Ao contrário do capital humano, o capital estrutural pode ser possuído e, portanto, negociado.

Na Skandia, empresa que, primeiramente, divulgou seu Balanço de Capital Intelectual em 1997, Edvinsson, juntamente com sua equipe de trabalho que desenvolvia o modelo de Capital Intelectual, chegou a três conclusões:

- O Capital Intelectual constitui informação suplementar e não subordinada às demonstrações financeiras;

- O Capital Intelectual é um capital não financeiro e representa a lacuna oculta entre o valor de mercado e o valor contábil;

- $\quad$ O Capital Intelectual é um passivo e não um ativo.

Edvinsson e Malone (1998) explicam que é fácil por que o Capital Intelectual não se enquadra nos modelos contábeis tradicionais. O Capital Intelectual, para eles, valoriza atividades como a lealdade dos clientes ou o desenvolvimento da competência dos empregados, que podem não influir na lucratividade de uma empresa durante anos. Dessa forma, o Capital Intelectual não atribui valor ao sucesso em curto prazo que não projete a empresa para o futuro.

A história empresarial recente mostrou, no entanto, que nenhuma de tais suposições é verdadeira. O núcleo da chamada "Economia do Conhecimento" é constituído por enormes fluxos de investimento em capital humano bem com em informática ou tecnologia da informação. E, de maneira impressionante, nem o Capital Intelectual nem o capital humano são considerados como valor positivo na Contabilidade tradicional. (CARIOLA et al., 2007).

Ocorre, com frequência, exatamente o contrário. Esses investimentos, porém, são os instrumentos fundamentais para a nova criação de valor. De alguma maneira, mesmo que por pressentimento e intuição, o mercado está atribuindo valor aos ativos invisíveis. (EDVINSSON; MALONE, 1998). 
Edvinsson e Malone (1998, p. 11) sugerem a indicação de um possível novo balanço:

CAPITAL INTELECTUAL

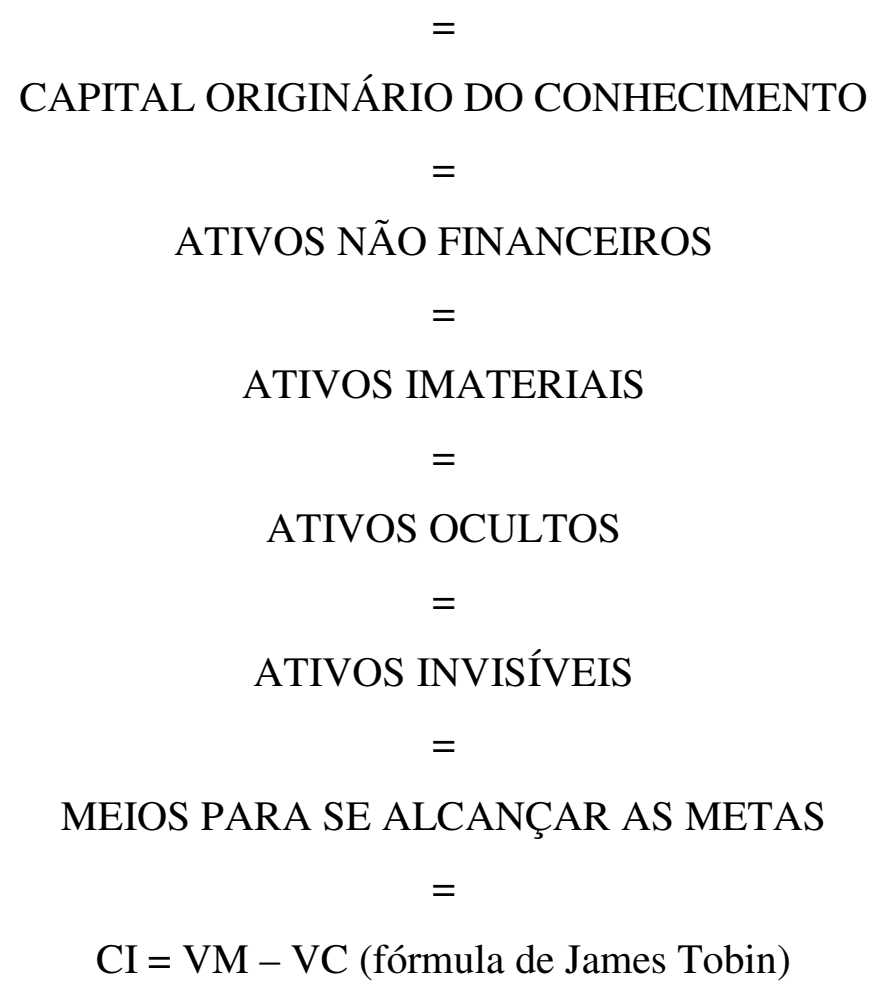

Edvinsson e Malone (1998) corroboram a visão de James Tobin e, para eles, essa fórmula demonstra que o Capital Intelectual de uma determinada empresa é igual ao seu Valor de Mercado (VM) menos o Valor Contábil (VC).

\subsubsection{Reconhecimento do Capital Intelectual}

Segundo as recomendações de reconhecimento de Ativo, as informações pertinentes à tomada de decisão devem constar das demonstrações contábeis. Sveiby (1997), em sua obra, destaca que há itens adicionais reconhecidos pelo mercado que a Contabilidade financeira não reconhece.

Antunes (2000) faz uma crítica a esse respeito, informando que a função da Contabilidade não é registrar o valor de mercado das companhias. 
Para Backes (2005):

[...] é necessário considerar que não seria confiável tomar o valor de mercado como fator determinante para explicar a existência de Capital Intelectual nas empresas. Uma coisa (sic) é acreditar que esses recursos criam valor para a organização e possuem valor, outra é atribuir a diferença entre a percepção do mercado acima dos valores contábeis estritamente a esses ativos intangíveis, pois precisam ser considerados inúmeros fatores que podem influenciar no mercado de ações.

Dessa maneira, não cabe a ideia de que o reconhecimento do Capital Intelectual preencheria a lacuna entre a diferença do valor de mercado e o valor contábil. Seu reconhecimento aumenta o valor da empresa, já que o valor do ativo total seria acrescido. Todavia, ratifica-se a ideia de que não se pode assumir o Capital Intelectual, item que equipararia valor contábil e valor de mercado (market value).

\subsubsection{Mensuração do Capital Intelectual}

Para El-Bannany (2008), a mensuração do Capital Intelectual é baseada no pressuposto de que a existência de capital físico, o capital humano, contribua para a criação de valor acrescentado. $\mathrm{O}$ autor afirma que o capital humano não pode agir sem o capital físico. Nessas condições, faz-se necessária a divulgação do Capital Intelectual, visto sua utilidade para a geração de valor para a entidade que o detém.

Santiago Jr. e Santiago (2007, p. 44 - 46) afirmam que os ativos intangíveis relacionados ao conhecimento e ao Capital Intelectual são os drivers (direcionadores) do crescimento e da agregação de valor na maioria dos setores da economia. No entanto, o uso de métodos que permitam a mensuração dessa contribuição ainda é uma questão que precisa de pesquisa por parte de acadêmicos e das empresas envolvidas nesse processo.

Devido à dificuldade na mensuração do Ativo Intangível, alguns modelos foram desenvolvidos para auxiliar nessa etapa do processo contábil. Sammartino (2002, p. 52) cita os seguintes modelos de avaliação do Capital Intelectual:

- Navegador Skandia: desenvolvido por Leif Edvinsson, em 1994, quando da publicação do Balanço da Skandia daquele ano, uma das maiores empresas da região da Escandinávia. Esse modelo possui como ponto fundamental a crença de que o valor real 
do desempenho de uma empresa está na habilidade de criar vantagens sustentáveis a partir da identificação de fatores de sucesso que suportem a estratégia de negócios estabelecida. O modelo possui alguns focos de avaliação como o financeiro, foco no cliente, no processo (tecnologia como instrumento para apoiar a criação de valor para a empresa), foco em renovação e desenvolvimento e, por último, foco humano, que inclui a competência e a capacidade de seus colaboradores.

- Monitor de Ativos Intangíveis, MAI, desenvolvido por Sveiby: esse modelo consiste num sistema de informações gerenciais para a mensuração dos ativos intangíveis. $\mathrm{O}$ modelo é apresentado por meio de três áreas de mensuração: indicadores de competência dos indivíduos, indicadores de estrutura interna e indicadores de estrutura externa.

- Modelo de Fitz-enz: desenvolvido por J. Fitz-enz, em 1997, o modelo busca desenvolver um sistema de avaliação no qual seja possível mensurar a contribuição das pessoas no desempenho organizacional. Para isso, são analisados os fatores como o nível de contribuição do capital humano para o atingimento das metas organizacionais, o impacto da ação humana na efetividade dos processos organizacionais. A gestão e a própria mensuração do capital humano a fim de determinar o valor agregado das pessoas para a organização em questão. A eficiência da atividade de gerir o capital humano pode ser mensurada a partir da criação de indicadores que monitoram o desempenho nas práticas da área de recursos humanos com os colaboradores.

- Métodos diretos de avaliação do Capital Intelectual: segundo Sammartino (2002), esses métodos procuram identificar e valorar monetariamente os componentes do Capital Intelectual e seus objetivos são a elaboração de estimativas de índices individuais e de coeficientes de correlação entre variáveis. Destaquem-se, entre esses métodos, o Método de Capitalização de Mercado e o Método de Retorno dos Ativos.

- “Q de Tobin”: esse modelo foi desenvolvido por James Tobin e tem por princípio a verificação do nível de influência do Capital Intelectual nas variações das ações da empresa. Capital Intelectual. A forma do "Q de Tobin" é a seguinte: "Q" = (VMA + VMD) / VRA, em que VMA pode ser definido como o valor de mercado das ações ou 
capital próprio; VMD como valor de mercado das obrigações da entidade ou capital de terceiros empregados e VRA pode ser considerado como valor de reposição dos ativos. De acordo com Tobin, o resultado da aplicação da fórmula é interpretado da seguinte forma: e 'Q' $<1$ - significa que a empresa possui ativos que valem menos do que seu custo de reposição, sendo improvável que a mesma compre novos ativos desse tipo e se 'Q' > 1 - indica que a empresa possui ativos que valem mais do que seu custo de reposição e a tendência é de que ela investirá mais nesse tipo de ativo. Cabe destacar que essa medida não foi desenvolvida, primeiramente, para medir o capital intelectual das empresas, mas possui aplicação para tal, por compreender-se que um 'Q'maior que 1 informa que a empresa possui, além do valor de reposição de seus ativos, uma força que lhe permite ganhos excedentes.

- $\quad$ Balanced Scorecard, BSC, desenvolvido por Kaplan e Norton em 1996: busca o equilíbrio entre os objetivos de curto e longo prazo das empresas e foi organizado a partir de quatro perspectivas: a financeira, a de mercado, a de processos internos e a de inovação e aprendizado. Os próprios autores do BSC definem o modelo como uma estrutura de traduzir a estratégia da empresa em termos operacionais.

Para Assaf Neto (2001, p. 240), o índice Q de Tobin significa o relacionamento entre o valor de mercado de uma empresa com o valor de reposição de seus ativos. É um índice bastante revelador do potencial de valorização da empresa, indicando a riqueza agregada pelo mercado como reflexo de seu poder de gerar lucros.

O referido autor explica que uma variante do Q de Tobin é o MVA (equivalente ao VMA), obtido pela diferença, e não pela relação proposta por Tobin, entre o valor de marcado e o valor de investimento dos ativos. É a riqueza que uma empresa gerou a seus acionistas, demonstrada em valores absolutos pelo retorno que puderam auferir de seus investimentos na empresa.

A dificuldade maior do Q de Tobin é o cálculo do valor de mercado da empresa e do preço de reposição de alguns ativos, principalmente aqueles de características mais específicas para uma empresa. Destaque-se que o Q de Tobin considera o valor total da empresa, inclusive seu goodwill. 
Cabe a crítica de Mouritsen e Bukh (2002) de que o BSC não é uma ferramenta específica para medir o Capital Intelectual. Segundo os autores, o BSC só deve ser considerado como uma ferramenta integrada de gestão focada em aspectos de gestão e estratégia organizacional.

\subsubsection{Evidenciação do Capital Intelectual}

Backes (2005) afirma que:

a evidenciação do Capital Intelectual pode ser uma alternativa para a Contabilidade atenuar as deficiências de informações sobre os recursos do conhecimento, principalmente, no que se refere à demanda de informação externa por acionistas e investidores.

Partindo da premissa de que o Capital Intelectual agrega valor à empresa, sua evidenciação, explicitada pelos componentes das demonstrações contábeis, é de grande valia para os diversos usuários interessados nos benefícios econômicos futuros provenientes da utilização e gerenciamento dos ativos disponíveis para a entidade.

A falta de critérios para a mensuração do Capital Intelectual acarreta subjetividade durante o processo de evidenciação, fator esse que pode distorcer e prejudicar a avaliação patrimonial das empresas em geral.

Importante mencionar é que o disclosure de informações pode revelar o nível de transparência da empresa e pode funcionar como instrumento de marketing, pois, ao evidenciar os seus recursos e estratégias, está se revelando para os usuários. Há de se considerar, no entanto, que algumas informações são mantidas em sigilo como, por exemplo, estratégias específicas de mercado e lançamentos de novos produtos, que somente são divulgadas no momento oportuno, situações em que a empresa se preserva, visando precaver-se da concorrência e outros fatores. (Id., 2005).

De qualquer forma, é imprescindível que haja a evidenciação do Capital Intelectual para suprir os usuários de informações que podem alterar sua decisão. Para as empresas, também, é importante, visto que serve como uma forma de mostrar sua estratégia ao longo do tempo e, ainda, uma prática de Governança Corporativa. 


\subsection{Bancos}

A função elementar dos bancos é proporcionar a intermediação financeira entre os poupadores de recursos e os tomadores, deficitários de recursos. Mayer e Duesenberry $(1993,43)$ definem os bancos como intermediários financeiros que colaboram com o sistema financeiro por três motivos: o fato de diminuírem os custos transacionais, permitirem a concessão de crédito a longo prazo e reduzirem o risco do mercado como um todo.

Lima et al. (2007, p. 4) explica em sua obra que o conceito de instituição financeira, adotado pelo Brasil, é o dado pela Lei da Reforma Bancária - Lei 4.595/64. O artigo 17 diz que:

as instituições financeiras são pessoas jurídicas públicas ou privadas, que têm como atividade principal ou acessória a coleta, intermediação ou aplicação de recursos financeiros próprios ou de terceiros, em moeda nacional ou estrangeira e a custódia de valor de propriedade de terceiros.

A fim de corroborar a afirmação de Lima, utiliza-se a definição de Mishkin (2000, p. 6) que diz que os bancos são instituições financeiras que aceitam depósitos e fazem empréstimos. No termo bancos estão incluídas empresas financeiras como: bancos comerciais, associações de empréstimo e poupança, bancos de desenvolvimento, cooperativas de crédito etc..

Além disso, o autor informa que os bancos centralizam, predominantemente, a oferta e a procura de capitais no mercado financeiro. Sendo a instituição financeira parte integrante do processo de intermediação, ela pode atuar como sujeito ativo ou passivo nas operações realizadas.

Como exemplo, poder-se-ia citar um banco que está na posição de devedor, ou seja, se recebe recursos, portanto, tem a obrigação de devolver, no futuro, o valor recebido, eventualmente, acrescido de juros, tem-se uma operação passiva. Contudo, se o banco empresta os recursos a um tomador e passa a ter direito de receber, no valor, o valor emprestado acrescido de juros, tem-se uma operação ativa.

As operações passivas mais comuns são os depósitos e conta corrente. Outras operações ativas que podem ser citadas são os empréstimos, financiamentos e descontos. 
El-Bannany (2008) afirma que o setor bancário é baseado, essencialmente, em conhecimentos, ou seja, no Capital Intelectual e que o capital físico não é o determinante mais importante no processo de criação de riqueza. Além disso, declara que o setor bancário em geral, oferece uma área ideal de Capital Intelectual para investigação, porque a natureza das empresas do setor bancário está repleta de Capital Intelectual. 



\section{PROCEDIMENTOS METODOLÓGICOS}

\subsection{Introdução}

O presente capítulo tem por finalidade descrever os principais aspectos da pesquisa realizada, por meio do entendimento de seus procedimentos metodológicos, das técnicas empregadas para seu desenvolvimento e das informações concernentes aos dados ora tratados para a confecção de uma dissertação.

A dissertação pode ser entendida como um trabalho acadêmico que abrange a releitura e encadeamento de ideias para a obtenção do título de mestre. Salvador (1980, p. 35) classifica o termo dissertação como:

[...] um estudo teórico, de natureza reflexiva, que consiste na ordenação de idéias sobre um determinado tema. Exige, por isso, a capacidade de sistematização de dados coletados, sua ordenação e interpretação.

Dessa forma, para a elaboração de uma dissertação, faz-se necessária uma releitura de textos e obtenção de informações que são colhidas e tratadas fazendo uso de diversos métodos de pesquisas. Collis e Hussey (2005) acreditam que para que seja realizada a produção acadêmica é necessária a prática de pesquisa. Entretanto, esses autores explicam que não há um consenso na literatura de como o termo pesquisa é definido.

Collis e Hussey (2005, p. 14) esclarecem, porém, que nas definições existentes de pesquisa há sempre a ideia de que ela se constitui um processo de perguntas e investigações, conduzida de maneira sistemática e metódica. Além disso, os autores afirmam que a pesquisa faz com que aumente o nível de conhecimento para a humanidade.

Segundo Martins e Théophilo (2007, p. 5), faz-se necessária a identificação de um tema para a realização da pesquisa. $\mathrm{O}$ tema a ser analisado precisa ser problematizado, isto é, carece de uma formulação que contenha clareza e exatidão daquilo que será estudado. Além disso, os autores sugerem que o problema de pesquisa pode ser expresso, preferencialmente, em forma 
interrogativa, buscando, dessa forma, o relacionamento entre variáveis que compõem a problemática.

\subsection{Tipo de pesquisa}

Segundo Köche (1999 apud ANTUNES 2004, p. 140), "a Ciência se apresenta como um processo de investigação que procura atingir conhecimentos sistematizados sendo necessário um planejamento." Informa, ainda, que o planejamento da pesquisa depende tanto do problema a ser investigado, de sua natureza e situação espaço temporal em que se encontra, quanto da natureza e nível de conhecimento do pesquisador.

Gil (2002, p. 19) define pesquisa como o procedimento racional e sistemático que tem como objetivo proporcionar respostas aos problemas que são propostos. Afirma que a pesquisa é desenvolvida mediante o concurso de conhecimentos disponíveis e a utilização cuidadosa de métodos, técnicas e outros procedimentos científicos.

Ademais, o autor enfatiza que a pesquisa tem como missão estruturar as informações para responder a determinados problemas ou quando uma informação disponível se encontra em tal estado de desordem que não possa ser, adequadamente, relacionada ao problema em questão.

Collis e Hussey (2005, p. 24) classificam as pesquisas como exploratória, descritiva, analítica e preditiva. Seguem suas definições:

- A pesquisa exploratória é aquela realizada sobre um problema ou questão de pesquisa quando há poucos ou nenhum estudo anterior em que se possa buscar informações sobre a questão ou problema. Seu objetivo é procurar padrões, ideias ou hipóteses, em vez de testar ou confirmar uma hipótese.

- $\quad$ Pesquisa descritiva é a pesquisa que descreve o comportamento dos fenômenos. É usada para identificar ou obter informações sobre as características de um problema ou questão. 
- Pesquisa analítica, também denominada explanatória, é uma continuação da pesquisa descritiva. Tem como objetivo entender fenômenos, descobrindo e mensurando relações causais entre eles.

- A pesquisa preditiva vai, ainda, além da pesquisa explanatória. Oferece uma explicação para o que está acontecendo em determinada situação, enquanto a explanatória prediz a probabilidade de uma situação semelhante acontecer em outro lugar.

Gil (2002), por sua vez, divide os tipos de pesquisas em três grupos: pesquisas exploratórias, pesquisas descritivas e pesquisas explicativas. As pesquisas exploratórias têm como objetivo proporcionar maior familiaridade com o problema, com vistas a torná-lo mais explícito ou a construir hipóteses.

As pesquisas descritivas têm como objetivo primordial a descrição das características de determinada população ou fenômeno ou, então, o estabelecimento de relações entre variáveis. O último grupo, pesquisas explicativas, tem como preocupação central identificar os fatores que determinam ou que contribuem para a ocorrência dos fenômenos.

Martins e Theóphilo (2007) subdividem as pesquisas em suas estratégias de realização. Uma dessas divisões é a pesquisa documental, caracterizada como um estudo que utiliza documentos como fonte de dados, informações e evidências para sua elaboração.

Levando-se em conta as definições acima discutidas, esta pesquisa é classificada como documental, em que a forma de coleta de dados é feita em relação a documentos, especificamente nas demonstrações contábeis dos bancos brasileiros e espanhóis, suas notas explicativas, relatórios de administração e demais relatórios financeiros.

O trabalho pode, também, ser classificado como descritivo, pois visa a descrever o tipo e a quantidade de itens que compõem o Capital Intelectual divulgados pelos bancos abertos nos países supracitados. 


\title{
3.3 Método de pesquisa
}

O estudo desenvolvido utilizará somente o método qualitativo, que consiste na busca e análise de informações não necessariamente organizadas para a compreensão de um determinado fenômeno ou acontecimento.

A pesquisa qualitativa caracteriza-se por solicitar descrições, compreensões e análises de informações, fatos, ocorrências, evidências que, naturalmente, são expressas por dados e números. Nesses casos, as técnicas de coleta são mais específicas, como, por exemplo, as entrevistas, observações, análise de conteúdo. (MARTINS; THEÓPHILO 2007, p. 135).

Por se caracterizar uma pesquisa estritamente qualitativa, não fazendo uso de métodos quantitativos, a pesquisa pode, ainda, ser classificada como fenomenológico-hermêutica, que, segundo Martins (2002, p. 27), pode assim ser explicada:

A pesquisa fenomenológico-hermêutico é um tipo de estudo cuja abordagem não utiliza técnicas quantitativas, privilegiando estudos teóricos de documentos e textos e que buscam relação entre o fenômeno e a essência, o todo e as partes, o objetivo e o contexto.

A diferença entre o método quantitativo e qualitativo e suas conceituações é explicada por Godoy (1995, p. 58 apud ANTUNES 2004, p. 143):

\begin{abstract}
Num estudo quantitativo o pesquisador conduz seu trabalho a partir de um plano estabelecido $a$ priori, com hipóteses claramente especificadas e variáveis operacionalmente definidas. Preocupase com a medição objetiva e quantificação de resultados. Busca a precisão, evitando distorções na etapa de análise e interpretação dos dados, garantindo assim uma margem de segurança em relação às inferências obtidas. De maneira diversa, a pesquisa qualitativa não preocupa enumerar e/ou medir eventos estudados. Parte de questões ou focos de interesse amplo, que vão se definindo à medida que o estudo se desenvolve. Envolve a obtenção de dados descritivos sobre pessoas, lugares, processos interativos pelo contato direto do pesquisador com a situação estudada, procurando compreender os fenômenos segundo a perspectiva dos participantes da situação de estudo.
\end{abstract}

O método qualitativo empregado nesta dissertação buscou a obtenção dos dados referentes ao Capital Intelectual nas publicações financeiras dos bancos atuantes nas bolsas do Brasil e da Espanha. Por ser um trabalho qualitativo, dispensou-se a formulação de hipótese de pesquisa. 
Gil (2002, p. 43) explica que, em alguns estudos, as hipóteses não são, obrigatoriamente, enunciadas na metodologia do trabalho, visto que o objetivo é o de descrever determinado fenômeno ou as características de um grupo.

\subsection{Universo da pesquisa}

O universo da pesquisa foi constituído pela seleção de todos os bancos que cotizam na Bolsa de Valores do Brasil e na Bolsa de Valores da Espanha, ou seja, as instituições financeiras que possuem suas ações negociadas nesses mercados organizados, respectivamente a BM\&FBOVESPA e a Bolsa de Madri.

\subsubsection{Bancos no Brasil}

Para a realização deste trabalho, optou-se por selecionar todos os bancos abertos listados na BM\&FBOVESPA. Após consulta no sítio da BM\&FBOVESPA (2008), foram detectadas 34 instituições financeiras cotizantes, porém 6 delas foram excluídas para a elaboração da pesquisa de informações.

As instituições excluídas eram classificadas como holdings de participação e administração financeira, ou seja, não caracterizam um banco. Utiliza-se, neste trabalho, o termo instituição financeira como equivalente ao termo banco, porém para que uma entidade seja caracterizada como banco ela deve desempenhar, necessariamente, as funções de um banco e não ser apenas uma empresa financeira que controla uma ou mais instituições financeiras ou não. Cabe destacar que dentre os bancos selecionados, está o Banco da Patagônia, banco que possui sede na Argentina, todavia suas ações, igualmente, estão listadas na BM\&FBOVESPA.

As holdings financeiras, excluídas da pesquisa foram Renner Participações S.A., Unibanco Holdings S.A. (Controladora do Banco Unibanco S.A.), Votorantim Finanças S.A., Consórcio Alfa de Administração S.A., Alfa Holdings S.A. e Itaúsa (Controladora financeira do Banco Itaú e Banco Itaú BBA). 
Martins (2002, p. 20) define população como sinônimo de universo, ou seja, população pode ser considerada como a totalidade de itens, objetos ou pessoas sob consideração de um determinado estudo.

Como o referido estudo utilizará somente os bancos de capital aberto, pode-se considerar como população os elementos selecionados a partir da listagem da BM\&FBOVESPA. Assim sendo, os bancos ora selecionados constituem uma população para a elaboração desta pesquisa.

O Quadro 2 descreve os bancos selecionados, contendo o nome de pregão que é utilizado em bolsa, sua razão social e suas atividades principais, segundo classificação da própria BM\&FBOVESPA (2008).

Quadro 2 - Bancos que cotizam na BM\&FBOVESPA

\begin{tabular}{|c|c|c|c|}
\hline \# & $\begin{array}{l}\text { Nome de } \\
\text { Pregão } \\
\end{array}$ & Razão Social & $\begin{array}{c}\text { Atividade Principal } \\
\text { (Classificação BM\&FBOVESPA) }\end{array}$ \\
\hline 1 & Banestes & Banestes S.A. - Banco do Estado do ES & Banco Múltiplo \\
\hline 2 & ABC Brasil & Banco ABC Brasil S.A. & Banco Múltiplo \\
\hline 3 & Alfa Invest & Banco Alfa de Investimento S.A. & Banco de Investimento \\
\hline 4 & Amazonia & Banco Amazonia S.A & $\begin{array}{l}\text { Prestação de Serviços/Oper. } \\
\text { bancárias / desenvolvimento }\end{array}$ \\
\hline 5 & Bradesco & Banco Bradesco S.A. & $\begin{array}{l}\text { Operações Bancárias, inclusive } \\
\text { Câmbio }\end{array}$ \\
\hline 6 & Brasil & Banco do Brasil S.A. & $\begin{array}{l}\text { Todos os serviços autorizados para } \\
\text { Banco Comercial }\end{array}$ \\
\hline 7 & Cruzeiro Sul & Banco Cruzeiro do Sul S.A. & Banco Múltiplo \\
\hline 8 & Daycoval & Banco Daycoval S.A. & Banco Múltiplo \\
\hline 9 & BESC & Banco do Estado de Santa Catarina S.A. & Banco Comercial \\
\hline 10 & Banese & $\begin{array}{l}\text { Banco do Estado de Sergipe S.A. - } \\
\text { BANESE }\end{array}$ & Operações Bancárias \\
\hline 11 & Banpara & Banco do Estado do Pará S.A. & Bancária \\
\hline 12 & Est Piaui & Banco do Estado do Piauí S.A. & Finanças \\
\hline 13 & Banrisul & $\begin{array}{l}\text { Banco do Estado do Rio Grande do Sul } \\
\text { S.A. }\end{array}$ & Banco Múltiplo \\
\hline 14 & BicBanco & Banco Industrial e Comercial S.A. & Banco Múltiplo \\
\hline 15 & Indusval & Banco Indusval S.A. & $\begin{array}{l}\text { Banco Comercial com autorização } \\
\text { para op. de câmbio }\end{array}$ \\
\hline 16 & Itaubanco & Banco Itaú Holding Financeira S.A. & Banco Múltiplo \\
\hline 17 & Merc Invest & Banco Mercantil de Investimentos S.A. & Investimentos / Financiamentos \\
\hline 18 & Merc Brasil & Banco Mercantil do Brasil S.A. & Finanças, Banco Múltiplo \\
\hline 19 & Nord Brasil & Banco do Nordeste do Brasil S.A. & $\begin{array}{l}\text { Banco Múltiplo com Carteira de } \\
\text { Crédito Comercial }\end{array}$ \\
\hline 20 & Nossa Caixa & Banco Nossa Caixa S.A. & $\begin{array}{l}\text { Operações Bancárias / Banco } \\
\text { Múltiplo }\end{array}$ \\
\hline 21 & Panamericano & Banco Panamericano S.A. & $\begin{array}{l}\text { Banco Múltiplo com Carteira } \\
\text { Comercial }\end{array}$ \\
\hline
\end{tabular}


continuação

\begin{tabular}{|c|c|l|l|}
\hline$\#$ & $\begin{array}{c}\text { Nome de } \\
\text { Pregão }\end{array}$ & \multicolumn{1}{|c|}{ Razão Social } & $\begin{array}{c}\text { Atividade Principal } \\
\text { (Classificação BM\&FBOVESPA) }\end{array}$ \\
\hline 22 & Pine & Banco Pine S.A. & $\begin{array}{l}\text { Banco Múltiplo com Carteira } \\
\text { Comercial }\end{array}$ \\
\hline 23 & Santander BR & Banco Santander S.A. & Banco Múltiplo \\
\hline 24 & Sofisa & Banco Sofisa S.A. & Banco Múltiplo \\
\hline 25 & BRB Banco & BRB Banco de Brasília S.A. & Banco Comercial \\
\hline 26 & Parana & Paraná Banco S.A. & Banco Múltiplo \\
\hline 27 & Unibanco & $\begin{array}{l}\text { Unibanco - União de Bancos Brasileiros } \\
\text { S.A. }\end{array}$ & Bancária - Banco Múltiplo \\
\hline 28 & Patagonia & Banco Patagonia S.A. & Banco Múltiplo \\
\hline
\end{tabular}

\subsubsection{Bancos na Espanha}

Para a seleção dos bancos que cotizam na Espanha, foi consultado o sítio da Bolsa de Madri (2008) e utilizado o mesmo processo para os bancos atuantes no Brasil, ou seja, foram selecionadas todas as entidades classificadas como instituição financeira - termo equivalente ao espanhol - "Servicios Financieros e Inmobiliarios - Bancos/Cajas Ahorro" - segundo classificação original.

Foram encontradas 20 ocorrências, porém somente 9 foram consideradas para a realização da composição da pesquisa. Dessa forma, a população de bancos abertos que atuam na Espanha utilizada nesta dissertação é composta somente por 9 instituições financeiras. Dessas 9 instituições consideradas, 8 possuem origem espanhola e 1 origem chilena, o Banco de Chile.

Do total das instituições listadas, inicialmente, 11 foram desconsideradas para a pesquisa. A primeira delas foi a "Caja de Ahorros del Mediterraneo", pois não é considerada como banco pela padrão espanhol, visto que opera somente com captação de recursos de poupança. Outras 6 instituições financeiras (Banco da Andalucia S.A., Banco de Castilla S.A., Banco de Credito Balear S.A, Banco de Galicia S.A. e Banco de Vasconia S.A) são consolidadas pelo Banco Popular e, dessa forma, foram excluídas para que não houvesse possíveis duplicidades.

O BBVA Banco Frances é consolidado pelo BBVA e o Banco Santander Rio e o Banco Banesto são consolidados pelo Grupo Santander. Por último, havia o Banco Bradesco, de origem brasileira. Essa instituição foi desconsiderada da população, pois apresenta à bolsa espanhola as mesmas demonstrações contábeis apresentadas no Brasil, pelo fato de a Bolsa Espanhola aceitar esses relatórios financeiros num padrão diferente do seu. Para que, também, 
não houvesse duplicidade das informações, decidiu-se retirar o referido banco da população pesquisada.

O Quadro 3 apresenta os bancos que atuam na Espanha por meio de sua razão social.

Quadro 3 - Bancos que cotizam na Bolsa de Madri
\begin{tabular}{|l|l|}
\hline$\#$ & \multicolumn{1}{|c|}{ Razão Social } \\
\hline 1 & Banco Bilbao Vizcaya Argentaria, S.A. \\
\hline 2 & Banco de Sabadell, S.A. \\
\hline 3 & Banco de Valencia, S.A. \\
\hline 4 & Banco Guipuzcoano, S.A. \\
\hline 5 & Banco Pastor, S.A. \\
\hline 6 & Banco Popular Español, S.A. \\
\hline 7 & Banco Santander, S.A. \\
\hline 8 & Bankinter, S.A. \\
\hline 9 & Banco de Chile S.A. \\
\hline
\end{tabular}

\subsection{Tratamento dos dados}

\subsubsection{Análise de conteúdo}

Com o intuito de responder à questão de pesquisa formulada, adotou-se a técnica denominada Análise de Conteúdo. Essa técnica é caracterizada como uma análise das informações contidas em diversos tipos de documentos.

Segundo Bardin (2004, p. 40), a Análise de Conteúdo pode ser definida da seguinte maneira:

\footnotetext{
Análise de Conteúdo é um conjunto de técnicas das comunicações visando obter, por procedimentos sistemáticos e objetivos de descrição do conteúdo das mensagens, indicadores (quantitativos ou não) que permitam a inferência de conhecimentos relativos às condições de produção/ recepção (variáveis inferidas) destas mensagens.
}

A Análise de Conteúdo caracteriza-se como a técnica que melhor pode ser empregada para o desenvolvimento deste trabalho, cujo objetivo é conhecer a evidenciação e quais informações são divulgadas em relação ao Capital Intelectual. A busca dessas informações se dará por meio de leituras e análises das demonstrações contábeis, notas explicativas, relatórios de administração, relatórios anuais e demais relatórios financeiros dos bancos selecionados. 
Com a finalidade de extrair informações contidas em documentos, Martins e Theóphilo (2007 p. 96) afirmam:

A análise de Conteúdo busca a essência de um texto nos detalhes das informações, dados e evidências disponíveis. Não trabalha somente com o texto de per se, mas também com detalhes de contexto. $\mathrm{O}$ interesse não se restringe à descrição dos conteúdos. Deseja-se inferir sobre o todo da comunicação. Entre a descrição e a interpretação, interpõe-se a inferência. Busca-se entendimentos sobre as causas e antecedentes da mensagem, bem como seus efeitos e conseqüência.

A análise documental pode ser explicada, também, como uma operação ou conjunto de operações que visa a representar o conteúdo de um documento sob a forma diferente da original, a fim de facilitar num estudo anterior a sua consulta e referência. (BARDIN, 2004, p.40).

Para alcançar tal objetivo, utilizaram-se as classificações do Capital Intelectual elaboradas por Edvinsson e Malone (1998) com adaptações necessárias para que houvesse maior adequação do estudo à realidade pesquisada, ou seja, a forma como o Capital Intelectual é divulgado pelas instituições financeiras que cotizam no Brasil e na Espanha.

Trata-se, dessa forma, de uma análise documental, em que é necessário revisar todos os documentos ora empregados a fim de capturar as possíveis evidenciações dos grupos que compõem o Capital Intelectual. Para cada item, frase, sentença ou período que remeta a um item ou subitem do Capital Intelectual será realizado um apontamento de evidenciação.

\subsubsection{Coleta e tratamento de dados}

Bardin (2004, p. 89) classifica a utilização da Análise de Conteúdo em três fases:

- $\quad$ Pré-análise;

- $\quad$ Exploração do material;

- $\quad$ Tratamento de resultados, inferência e interpretação.

Segundo essa divisão, a primeira fase, pré-análise, tem como finalidade a organização e a estruturação do material coletado / selecionado a fim de saber como poderá ser pesquisado e 
como extrair as informações de que o pesquisador necessita para o desenvolvimento de sua pesquisa.

A pré-análise, no caso dos bancos brasileiros, foi o acesso ao sítio de BM\&FBOVESPA (2008), na qual foi encontrada a relação de todos os bancos brasileiros e estrangeiros abertos. Posteriormente, utilizando o software DivExt, Divulgação Externa, foram coletados todos os arquivos que continham os dados das demonstrações financeiras referentes aos 28 bancos que listam suas ações na bolsa

Além disso, foi realizada pesquisa em cada sítio dos bancos para verificar se havia arquivos adicionais aos disponibilizados, primariamente, no sítio da BM\&FBOVESPA. Para os bancos que realizam capitalização bursátil na bolsa espanhola foi adotado procedimento semelhante, com exceção à extração de informações referentes ao software utilizado, visto que o DivExt é um programa gratuito que atende, somente, as empresas que são listadas na BM\&FBOVESPA.

Além disso, não há estrutura equivalente de disponibilização de dados na Bolsa de Madri como ocorre na BM\&FBOVESPA, em que há um programa específico para o tratamento e agrupamento das informações referentes às instituições financeiras.

Para que as demonstrações contábeis, notas explicativas e relatórios de administração dos bancos atuantes na Espanha fossem coletados, acessou-se a página da Internet de cada uma das instituições, nas quais as informações foram encontradas e capturadas.

As informações coletadas tanto para os bancos atuantes no Brasil quanto na Espanha compreendem os exercícios sociais dos anos de 2006, 2007 e do 1S08, primeiro semestre de 2008. A utilização desse intervalo visa a estudar a possível evolução da evidenciação do Capital ao longo do tempo.

A fase de exploração do material consistiu na leitura de cada um dos relatórios contábeis, notas explicativas, relatórios de administração e demais relatórios que pudessem conter informações ligadas, direta ou indiretamente, ao Capital Intelectual. O tratamento dos resultados e a interpretação foram abordados mediante a análise das informações obtidas na leitura do material selecionado e das informações adquiridas. 
Como citado no item 3.5.1 - Análise de dados - a unidade de análise para a categorização e divulgação do Capital Intelectual foi o termo, frase, oração ou sentença que remeta ao conceito ou ideia do objeto de estudo. Por meio da ocorrência desses itens nos informes contábeis e demais relatórios, foram realizados a organização e o estudo de suas frequências e ocorrências.

Para a análise desses relatórios contábeis, utilizaram-se as três divisões do Capital Intelectual propostas por Edvinsson e Malone (1998), que consistem em Capital Humano, Capital Estrutural e Capital de Clientes.

Para a elaboração das subdivisões, foram empregados os itens utilizados por Backes (2005) em sua dissertação de mestrado. Backes (2005, p. 126) afirma em relação à escolha das categorias e subcategorias que:

\footnotetext{
As categorias foram formadas tomando-se por base o referencial estudado, adotando-se a classificação de capital intelectual sugerida pelo referencial teórico em relação aos componentes de capital intelectual (EDVINSSON; MALONE, 1998) e, praticamente, comum a todos os autores referenciados: capital humano, capital estrutural e capital de clientes. Na definição das subcategorias considerou-se o referencial estudado, mais precisamente, os autores no item componentes de capital intelectual. (EDVINSSON; MALONE, 1998; STEWART, 1998; BROOKING, 1997 e SVEIBY, 1998).
}

Todavia, realizaram-se adaptações com o intuito de adequar essas subdivisões empregadas pela autora à realidade das instituições financeiras, visto que em sua pesquisa original Backes (2005) não estudou somente os bancos e, sim, as empresas abertas de diversos segmentos. O Quadro 4, a seguir, mostra as categorias utilizadas pela autora. 


\begin{tabular}{|c|c|c|c|}
\hline \multicolumn{4}{|c|}{ Categorias de Capital Intelectual } \\
\hline 1 & Capital Humano & 2 & Cap ital Estrutural \\
\hline 1.1 & Ativo/Recurso & 2.1 & Qualidade em Tecnologia da Informação \\
\hline 1.2 & Incentivo a Nov as Idéias & 2.2 & Investimentos em TI \\
\hline 1.3 & Investimento em Educação dos Funcionários & 2.3 & Propriedade Intelectual \\
\hline 1.4 & Treinamento/Desenv olvimento/Capacitação & 2.4 & Patentes \\
\hline 1.5 & Politica de Retenção de Talentos & 2.5 & Direitos Autorais \\
\hline 1.6 & Politica de Captação de Talentos & 2.6 & Qualidade dos Produtos e Serviços \\
\hline 1.7 & Qualificação Profissional ( $\mathrm{n}^{\circ}$ de gerentes) & 2.7 & Inov ação/Pesquisa e Desenvolv imento \\
\hline 1.8 & Nivel de Escolaridade & 2.8 & Marcas Corporativas \\
\hline 1.9 & Turnover & 2.9 & Marcas de Produtos \\
\hline 1.10 & Beneficios & 2.10 & Cultura Organizacional \\
\hline 1.11 & Clima Organizacional & 2.11 & Práticas Ambientais \\
\hline & & 2.12 & Responsabilidade Social \\
\hline & & 2.13 & Governança Corporativa \\
\hline 3 & \multicolumn{3}{|c|}{ Capital de Clientes } \\
\hline 3.1 & Carteira de Clientes & 3.10 & Participação no Mercado \\
\hline 3.2 & Lealdade/Fidelidade dos Clientes & 3.11 & Treinamento do Cliente \\
\hline 3.3 & Captação de Clientes & 3.12 & Inovação Focada no Cliente \\
\hline 3.4 & Retenção de Clientes & 3.13 & Empowerment do Cliente \\
\hline 3.5 & Satisfação do Cliente & 3.14 & Customização \\
\hline 3.6 & Inv estimentos em TI/Cliente & 3.15 & Contratos de Franquias \\
\hline 3.7 & Suporte ao Cliente & 3.16 & Contratos de Licenças \\
\hline 3.8 & Parcerias Clientes/Fornecedores & 3.17 & Repetitividade dos Negócios \\
\hline 3.9 & Relacionamento com o Cliente/Fornecedor & 3.18 & Imagem da Empresa \\
\hline
\end{tabular}

Quadro 4 - Categorias do Capital Intelectual

Fonte: Backes (2005, p. 128)

Levando-se em conta as divisões realizadas por Edvinsson e Malone (1998) e Backes (2005), foi realizada nova subcategorização dos itens que compõem o Capital Intelectual para atender aos propósitos desta dissertação. Os novos itens componentes de cada uma das subdivisões do Capital Intelectual são apresentados nos Quadros 5, 6 e 7:

Quadro 5 - Capital Humano

1.1 - Colaboradores considerados como ativo da empresa

1.2 - Incentivo, adoção e implementação a novas ideias

1.3 - Investimento em educação especializada e/ou internacional

1.4 - Política de retenção e captação de talentos

1.5 - Nível de escolaridade

1.6 - Número de funcionários, gerentes e gestores

1.7 - Turnover

1.8 - Benefícios (além dos exigidos por lei)

1.9 - Clima organizacional 
Quadro 6 - Capital Estrutural

2.1 - Características e investimentos em TI

2.2 - Propriedade Intelectual

2.3 - Patentes, direitos autorais

2.4 - Marcas corporativas / Brands

2.5 - Quantidade e qualidade de canais e agências

2.6 - Inovação, pesquisa de produtos financeiros (P\&D)

2.7 - Cultura organizacional

2.8 - Práticas de responsabilidade social

2.9 - Práticas de sustentabilidade / responsabilidade ambiental

Quadro 7 - Capital de Clientes

3.1 - Carteira de Clientes

3.2 - Lealdade / fidelidade de clientes

3.3 - Captação, retenção e conquista de clientes

3.4 - Satisfação e relacionamento com clientes

3.5 - Operações estruturadas com clientes

3.6 - Relacionamento com fornecedores e stakeholders

3.7 - Investimentos em TI / clientes e serviços de Internet

3.8 - Treinamento e inovação focada nos clientes

3.9 - Market Share, participação no mercado 



\section{APRESENTAÇÃO DOS RESULTADOS}

\subsection{Considerações iniciais}

A finalidade do Capítulo 4 é apresentar e analisar os dados coletados das instituições financeiras tomadas como base de pesquisa. Destaque-se o fato de que os conjuntos dos bancos foram analisados separadamente em duas populações para posterior análise e confronto das informações obtidas em relação à divulgação de itens que compõem o Capital Intelectual.

\subsection{Bancos atuantes no Brasil}

Averiguou-se que, nos três períodos analisados, exercícios de 2006, 2007 e 1S08, a divisão que mais apresentou itens evidenciados no Brasil foi o Capital Estrutural, em que estão inseridos os itens relativos à tecnologia da informação, marcas, patentes e propriedades intelectuais e, por último, práticas de responsabilidade social, sustentabilidade e responsabilidade ambiental. Posteriormente, a divisão que apresentou mais dados evidenciados foi Capital Humano e, por último, a divisão Capital de Clientes.

Verificou-se que as principais informações concernentes ao Capital Intelectual estão destacadas nos relatórios de administração dos bancos e seus relatórios anuais. Nas demonstrações contábeis, propriamente analisadas, Balanço Patrimonial, Demonstração de Resultado, Demonstração de Origens e Aplicações de Recursos e Demonstração dos Fluxos de Caixa não foram encontradas dados específicos que fizessem referência, direta ou indireta, ao tema estudado.

Não foi considerado para este estudo o item distribuição do valor adicionado gerados pelas empresas aos colaboradores e encargos (item 8.1 da DVA, Demonstração do Valor Adicionado) por entender que tal item não se refere ao Capital Intelectual. O item 8.1 da DVA, aqui citado, refere-se à divisão proposta por Iudícibus et al. (2007, p. 502). 
Além disso, pode-se afirmar que as notas explicativas às demonstrações contábeis possuem pouquíssimos itens que remetem à evidenciação do Capital Intelectual. A única exceção a essa afirmativa é o disclosure que em alguns bancos apresentam ocorrências sobre seu plano de previdência privada, no qual a instituição divulga os números relativos ao plano de benefícios aos seus colaboradores e, às vezes, o percentual que investem nesses planos.

Outro ponto a ser comentado é que não houve crescimento significativo de itens evidenciados do exercício de 2006 para 2007. Partiu-se de 2.944 itens divulgados em 2006 para 3.042, ou seja, um modesto crescimento de 3,3\% de um período para outro. Além disso, deve-se considerar a drástica caída de nível de disclosure de itens do Capital Intelectual nas demonstrações do 1S08. Percebeu-se que houve uma forte redução de itens informados, saindo de 3.042 de 2007 para apenas 439 citações entre as três divisões utilizadas. Essa queda de itens divulgados deve-se, principalmente, a não publicação de relatórios de administração ou similares no período mencionado.

A análise das informações referentes à divulgação do Capital Intelectual será segregada, a seguir, para que haja maior compreensão e entendimento da forma como os bancos evidenciam cada componente que remete ao entendimento do Capital Intelectual em seu conjunto de demonstrações.

É importante mencionar que nem todos os bancos em estudo divulgaram itens sobre o Capital Intelectual em seus relatórios anuais e demais demonstrações. Todavia, um dos objetivos deste estudo é verificar se os bancos, no Brasil, estão aumentando a quantidade de informações divulgadas. A necessidade de disclosure pode ser afirmada pela citação de Lopes (2008, p.83) em que o autor menciona que o Brasil pode ser considerado como uma combinação única de má Governança Corporativa e ambientes institucionais com importantes oportunidades de crescimento econômico-financeiro.

\subsubsection{Capital Humano}

A população considerada para a elaboração deste estudo totalizou 28 bancos atuantes no Brasil conforme já destacado no Quadro 2. Os bancos que mais evidenciaram itens sobre o Capital Humano nos períodos analisados foram o Banco do Brasil (293 ocorrências), seguido pelo Banco Itaú (289), Banco Bradesco (212 ocorrências), Banco Santander (193 ocorrências) 
e Unibanco (177 ocorrências). A Tabela 1 mostra a quantidade de itens do Capital Humano evidenciado por cada banco no Brasil.

Tabela 1 - Distribuição de ocorrência do CH nos bancos no Brasil

\begin{tabular}{|c|c|c|}
\hline$\#$ & Bancos & Ocorrências \\
\hline 1 & Brasil & 293 \\
\hline 2 & Itaubanco & 289 \\
\hline 3 & Bradesco & 212 \\
\hline 4 & Santander BR & 193 \\
\hline 5 & Unibanco & 177 \\
\hline 6 & Nossa Caixa & 109 \\
\hline 7 & BicBanco & 102 \\
\hline 8 & Amazonia & 67 \\
\hline 9 & Banese & 51 \\
\hline 10 & BNB - Nordeste & 46 \\
\hline 11 & Indusval & 44 \\
\hline 12 & Banestes & 33 \\
\hline 13 & Sofisa & 33 \\
\hline 14 & BRB Banco & 33 \\
\hline 15 & Est Piauí (BEP) & 32 \\
\hline 16 & Banrisul & 32 \\
\hline 17 & Mercantil Brasil & 28 \\
\hline 18 & Pine & 22 \\
\hline 19 & ABC Brasil & 18 \\
\hline 20 & Parana & 18 \\
\hline 21 & BESC & 17 \\
\hline 22 & Panamericano & 16 \\
\hline 23 & Daycoval & 15 \\
\hline 24 & Banpara & 9 \\
\hline 25 & Cruzeiro do Sul & 8 \\
\hline 26 & Alfa Invest & 4 \\
\hline 27 & Patagonia & 3 \\
\hline 28 & Merc Invest & 0 \\
\hline \multicolumn{2}{|r|}{ Total } & 1.904 \\
\hline
\end{tabular}

O Banco do Brasil, BB, instituição financeira que mais apresentou itens sobre o Capital Humano, nos três períodos analisados, informa em seus relatórios de administração que segue o GRI, Global Reporting Initiative, instituição reconhecida internacionalmente que propõe um modelo de relatório adotado, em diferentes medidas, pelas organizações mais sustentáveis do planeta. Em 2006, o Relatório de Administração do Banco do Brasil passou de 98 para 382 páginas em 2007, distribuídas em 03 volumes (formato eletrônico). Em 1S08, o banco não 
apresenta um relatório de administração, apenas um relatório que mostra os principais resultados financeiros e contábeis.

O Banco do Brasil reforça em várias partes de seu Relatório Anual 2007 que consolida todas as iniciativas de práticas de evidenciação recomendadas pelo GRI em itens de Balanço Social devido à necessidade de manter os leitores de suas demonstrações bem informados. Comentam que o relatório é resultado do segundo ano de trabalho para a adequação ao padrão internacional (GRI), tomando-se por base os indicadores de terceira geração recomendados pela instituição.

Além disso, o BB informa que seu relatório anual é formulado por meio do diálogo com os públicos de interesse, em que foram determinados os indicadores relevantes para confecção desse report, destacando a importância dada à elaboração do documento. Mencionam que o referido contato com o público foi estabelecido por intermédio do 9o Prêmio Abrasca de Relatório Anual da Oficina GRI promovida pelo próprio banco.

As demandas recebidas para a elaboração de um adequado e informativo relatório anual, segundo o BB, partiram de diversos canais de comunicação da empresa como a Ouvidoria Interna para funcionários e colaboradores, a Ouvidoria Externa para clientes e para a sociedade em geral, e o canal "Fale com o RI", para analistas de mercado, acionistas, investidores e demais interessados.

O Banco Itaú ficou em segundo lugar no ranking de instituições atuantes no Brasil que mais divulgaram itens sobre o Capital Humano. A instituição afirma que seu Balanço Social auditado por firmas de auditoria independente e esse relatório passou a ser publicado a partir de 1999, alinhado às diretrizes propostas pelo Instituto Ethos. Posteriormente, a partir de 2004, o Banco Itaú, assim como o Banco do Brasil, passou a se pautar pela adoção das diretrizes e dos indicadores propostos pela GRI para a elaboração de seus relatórios de cunho social.

Por meio de pesquisas realizadas em seus sítios, constatou-se que tanto o GRI quanto o Instituto Ethos não possuem um modelo recomendado para a evidenciação de informações concernentes ao Capital Intelectual para bancos ou demais instituições financeiras. 
O Banco Itaú possui uma seção em seu Balanço Social em que destaca os ativos intangíveis dentro de seu RA. A instituição cita em seu BS de 2006 que "O maior valor do Itaú Holding está na qualidade de seus funcionários e no conhecimento que eles possuem. A atração, o desenvolvimento, a retenção e a integração de talentos constituem fortes focos de sua atuação". Tal afirmação remete ao fato do reconhecimento dos colaboradores como importante ativo da empresa, evidência da utilização do capital intelectual em suas atividades.

O Bradesco ocupou a terceira posição e possui uma seção em seu Relatório Anual chamada “Ativos Intangíveis”. Em 2006, essa seção possuía 100 páginas, baixando para 79 páginas no ano seguinte.

No 1S08 não houve evidenciações importantes sobre o Capital Humano por praticamente nenhuma das instituições analisadas. Caso fosse analisado esse período de maneira isolada, o banco que mais apresentou informações foi o Banco Santander (17 ocorrências), seguido pela Nossa Caixa (14 ocorrências) e pelo Banco BNB Nordeste (08 ocorrências).

Entre os componentes do Capital Humano que mais foram divulgados pelas instituições financeiras encontram-se os "Benefícios além dos exigidos por Lei". Dentre esses, os principais benefícios informados, os bancos citam os planos de previdência privada oferecidos aos seus colaboradores, itens ligados ao entretenimento e até alguns benefícios que se estendem aos familiares diretos dos funcionários. Os bancos que não citaram em nenhum dos períodos analisados itens que tratam sobre benefícios aos colaboradores foram o ABC Brasil, Banco Cruzeiro do Sul, Banpará, Banco do Estado do Piauí, Banco Mercantil de Investimentos - esse último não evidenciou nenhuma ocorrência do Capital Humano, conforme Tabela 1.

O Capital Humano destaca-se entre as subdivisões do Capital Intelectual em que estão inseridos os colaboradores detentores do conhecimento ainda não distribuído à entidade à qual pertencem. É importante frisar que o Capital Humano detido pelos colaboradores passa a ser Capital Estrutural quando institucionalizado dentro da organização. Essa institucionalização pode ser feita por meio de processos bem definidos e estrutura de disseminação de técnicas e conhecimentos empregados para a consecução das atividades da entidade. 
Sendo o ativo definido como a expectativa futura de benefícios econômicos de um determinado componente controlado pela entidade, o conhecimento e os próprios colaboradores dos bancos poderiam ser tratados como ativos da empresa. Isso posto, o item "Colaboradores considerados como ativo da empresa" só foi citado por somente 10 dos 28 bancos estudados.

As instituições que possuem maior ocorrência dessa citação são Unibanco (10 ocorrências), e Santander (com 9 citações cada), seguidos por Bradesco e Banco do Brasil (com 7 ocorrências cada). A Tabela 2 mostra as instituições bancárias que evidenciam esse item do Capital Humano em suas demonstrações contábeis.

Tabela 2 - Colaboradores considerados como Ativo da empresa em bancos no Brasil

\begin{tabular}{c|r|r}
\hline$\#$ & \multicolumn{1}{|c}{ Bancos } & Ocorrências \\
\hline 1 & Unibanco & 10 \\
\hline 2 & Santander BR & 9 \\
\hline 3 & Bradesco & 7 \\
\hline 4 & Brasil & 7 \\
\hline 5 & Itaubanco & 5 \\
\hline 6 & Amazonia & 4 \\
\hline 7 & Nossa Caixa & 4 \\
\hline 8 & Alfa Invest & 3 \\
\hline 9 & Banrisul & 2 \\
\hline 10 & Banestes & 1 \\
\hline & Total
\end{tabular}

Outro item ligado ao conhecimento dos colaboradores é o "Incentivo, adoção e implantação a novas ideias" que pode contribuir para a entidade. Somente 7 instituições divulgaram esse tipo de informação. Importante destacar é que a utilização de tal política de incentivo não implica sua efetiva implantação. Cabe mencionar mais uma vez que esta dissertação tem por objetivo verificar a quantidade de informação divulgada e não a sua efetiva adoção. $O$ disclosure desse item apenas reforça a ideia de que o banco se preocupa em envolver todos os seus colaboradores na busca por soluções que possam contribuir com a instituição como um todo.

O banco que mais divulgou essa informação, em seu relatório de administração, foi o Unibanco. Em 2006 e 2007, foram encontrados 6 itens sobre incentivos a novas ideias. No primeiro semestre de 2008, fez apenas uma menção a esse tipo de informação. Por último, 
cabe destacar que o Unibanco oferece, anualmente, o denominado Prêmio Moreira Salles de Incentivo de ideias, em que os colaboradores que apresentarem ideias que colaborem para o desenvolvimento do grupo são premiados e homenageados.

Um importante item ligado ao ensino e à educação continuada dos colaboradores, também, foi ponto de estudo. O maior destaque dados pelas instituições financeiras é o investimento realizado em cursos de MBA, Master Business Administration, cursos de pós-graduação ofertados aos colaboradores dentro da própria instituição. Esse tipo de curso, no qual as aulas são ministradas dentro da própria instituição é conhecido e citado como MBA in company e é mencionado pelos Bancos Itaú, Banco do Brasil e Santander.

Ademais, o Banco Santander menciona em seu relatório anual o programa "Novos Diretivos", em que alguns de seus colaboradores são expatriados. O banco cita que esses funcionários são reconhecidos como talentos e oferecem potencial de crescimento, segundo as métricas de avaliação do próprio banco. São enviados a outros países para trabalharem num período compreendido entre 24 a 36 meses dentro de um método equivalente ao job rotation, ou seja, passar por várias áreas do banco para ampliar o leque de conhecimento do negócio financeiro.

O Gráfico 1 evidencia as 10 maiores instituições atuantes no Brasil em termos de divulgação de itens de investimento em educação especializada ou em nível internacional.

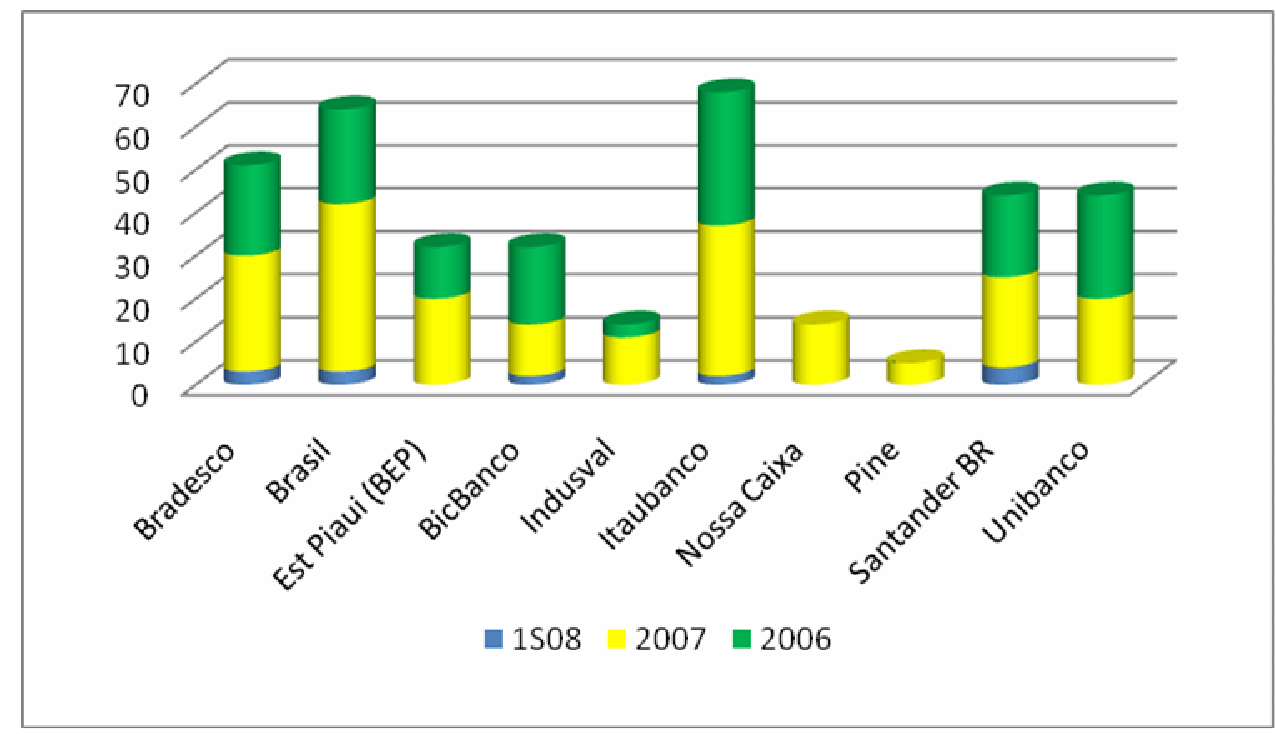

Gráfico 1 - Investimentos em educação especializada e/ou em nível internacional 
Um ponto a ser destacado, levando-se em conta o Gráfico 1, é o fato de o BEP, Banco do Estado do Piauí, instituição pública, demonstrar 12 ocorrências em 2006 e 20 ocorrências em 2007 e nenhuma em 1S08. Os bancos que divulgaram informações em 1S08 foram o Bradesco, Banco do Brasil, Itaú e Santander.

O nível de escolaridade, também, vem sendo divulgado com intensidade pelos bancos. Há um totalizador de 78 ocorrências no ano de 2007, um incremento de $69 \%$ em relação período anterior; no primeiro semestre de 2008, há apenas 6 ocorrências entre os bancos. O Gráfico 02 mostra a distribuição do ano de 2007 em relação ao disclosure de nível de escolaridade.

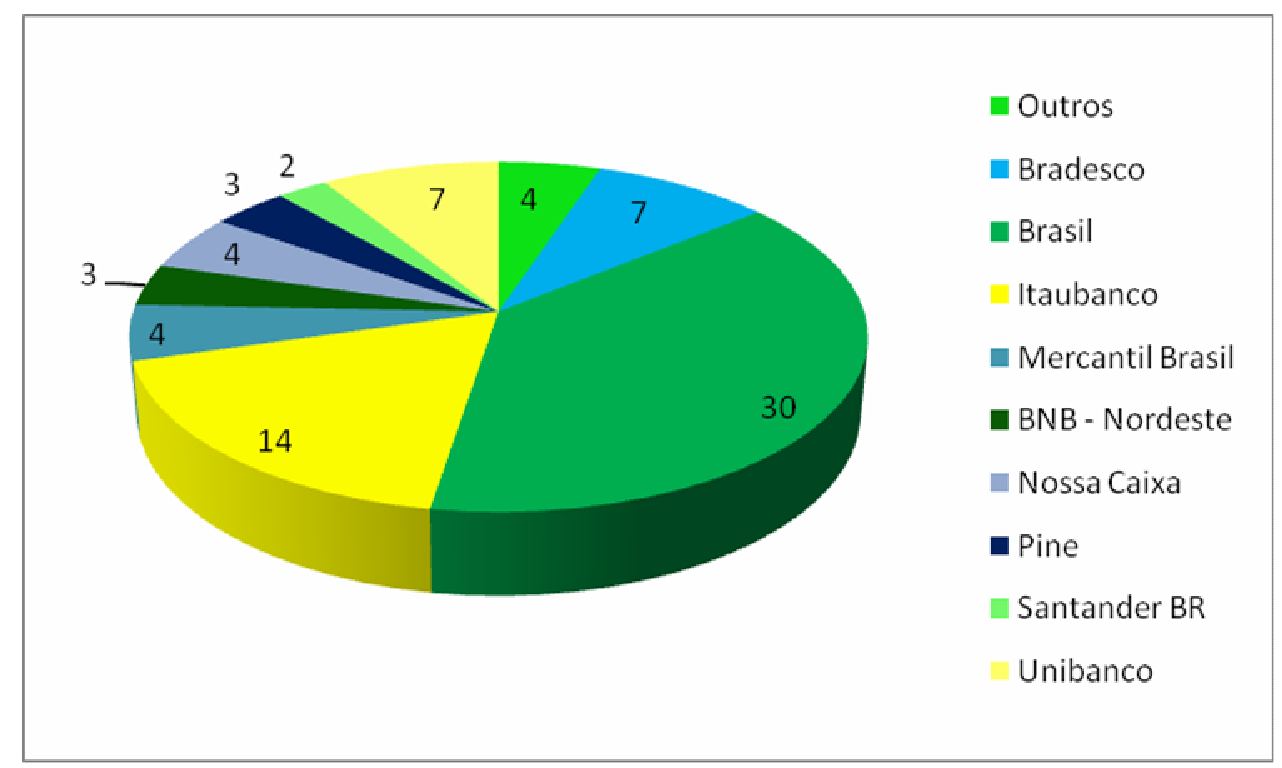

Gráfico 2 - Divulgação do nível de escolaridade nos bancos (2007)

Um ponto importante a comentar em relação à divulgação de informações é a preocupação dos bancos em mostrar a valorização do ser humano em suas demonstrações. Várias instituições citaram a importância do indivíduo como parte mais importante e fundamental da sociedade. Dentre eles, destaca-se o BRB Banco, Banco de Brasília, que em seu Relatório de Administração de 2007, afirma "não classificar as pessoas segundo critérios de etnia, uma vez que, segundo suas próprias palavras, por princípio, a instituição tem sua seleção privilegiada somente pelas competências do indivíduo para trabalhar empresa e ocupar cargos comissionados."

Ressalte-se que o Banco de Brasília foi o único a comentar que não utiliza como força de trabalho mão de obra infantil ou trabalho escravo, como também de não possuir envolvimento 
com prostituição ou exploração sexual de crianças ou adolescentes e, por último, não estar envolvido com corrupção.

Em relação ao turnover, conhecido, também, como a rotatividade de entrada e saída de colaboradores dentro da instituição, averiguou-se que não há muitas informações detalhadas sobre o item.

O fato de haver bancos públicos ou considerados como de economia mista faz com que muitos de seus colaboradores sejam contratados por meio de concurso público, em que a ocorrência de entradas e saídas é menor do que em bancos privados. Os bancos públicos identificados ou de economia mista encontrados neste trabalho são: Banco do Brasil, Banpará, Banco da Amazônia, BEP, Nossa Caixa, BNB Nordeste e BRB Banco. Todavia, mesmo nas instituições privadas, não foram encontradas muitas ocorrências sobre o turnover.

O último item a ser analisado em relação ao Capital Humano é o clima organizacional. Segundo Beker (2006, p. 19), o clima organizacional pode ser classificado como um elemento vital em um processo de gestão de mudanças, pois é, muitas vezes, visto como uma ferramenta de ajuste contínuo e fundamental na relação indivíduo-organização.

Além disso, as organizações que visam à eficácia e à eficiência podem atingir a primeira por meio da adaptação da organização à dinâmica de seu ambiente externo e a segunda pode ser aumentada pela criação de um clima organizacional que satisfaça as necessidades de seus membros e, ao mesmo tempo, canalize esse comportamento motivado na direção dos objetivos organizacionais.

O clima organizacional citado por 18 instituições foi considerado como um componente do Capital Humano das instituições, visto que o clima organizacional é responsável em parte pela motivação dos colaboradores dos bancos. Foi aludido, constantemente, que os colaboradores "passam boa parte de seu tempo no local de trabalho e que o clima organizacional impacta diretamente a produtividade, saúde mental e física dos colaboradores.”

Os bancos, em geral, consideram que possuem agradáveis ambientes de clima organizacional e dessa forma, asseguram que detêm um importante ativo para o andamento de suas operações. 


\subsubsection{Capital Estrutural}

O Capital Estrutural caracteriza, segundo as subdivisões adotadas nesta pesquisa, os itens ligados às características e investimentos em TI, itens de propriedade intelectual, marcas corporativas (brands), cultura organizacional, práticas de responsabilidade social e práticas de sustentabilidade e responsabilidade ambiental.

A Tabela 3 evidencia as ocorrências totais de itens do Capital Estrutural nos bancos atuantes no Brasil nos períodos analisados.

Tabela 3 - Divulgação dos itens de Capital Estrutural

\begin{tabular}{|c|c|c|c|c|c|}
\hline$\#$ & Bancos & TOTAL & $1 \mathrm{~S} 08$ & 2007 & 2006 \\
\hline 1 & Brasil & 523 & 13 & 269 & 241 \\
\hline 2 & Itaubanco & 518 & 7 & 261 & 250 \\
\hline 3 & Bradesco & 368 & 14 & 154 & 200 \\
\hline 4 & Amazonia & 351 & 66 & 71 & 214 \\
\hline 5 & Santander BR & 291 & 13 & 152 & 126 \\
\hline 6 & Unibanco & 257 & 2 & 113 & 142 \\
\hline 7 & Nossa Caixa & 205 & 24 & 91 & 90 \\
\hline 8 & Banese & 120 & 35 & 35 & 50 \\
\hline 9 & BNB - Nordeste & 74 & 5 & 67 & 2 \\
\hline 10 & Banrisul & 73 & 2 & 35 & 36 \\
\hline 11 & Indusval & 70 & 1 & 39 & 30 \\
\hline 12 & Sofisa & 63 & 0 & 48 & 15 \\
\hline 13 & BicBanco & 53 & 6 & 18 & 29 \\
\hline 14 & Banestes & 44 & 15 & 16 & 13 \\
\hline 15 & BRB Banco & 42 & 15 & 15 & 12 \\
\hline 16 & Mercantil Brasil & 35 & 2 & 18 & 15 \\
\hline 17 & Panamericano & 28 & 11 & 8 & 9 \\
\hline 18 & Pine & 25 & 8 & 17 & 0 \\
\hline 19 & Banpara & 20 & 2 & 8 & 10 \\
\hline 20 & ABC Brasil & 17 & 5 & 8 & 4 \\
\hline 21 & Est Piaui (BEP) & 15 & 0 & 9 & 6 \\
\hline 22 & Cruzeiro do Sul & 13 & 1 & 6 & 6 \\
\hline 23 & Parana & 11 & 2 & 6 & 3 \\
\hline 24 & Patagonia & 10 & 5 & 5 & 0 \\
\hline 25 & BESC & 8 & 0 & 2 & 6 \\
\hline 26 & Daycoval & 7 & 1 & 5 & 1 \\
\hline 27 & Alfa Invest & 3 & 0 & 2 & 1 \\
\hline 28 & Merc Invest & 0 & 0 & 0 & 0 \\
\hline & Total & 3.244 & 255 & 1.478 & 1.511 \\
\hline
\end{tabular}


Semelhantes à classificação de instituições que mais divulgavam itens do Capital Humano, a liderança de itens evidenciados em relação ao Capital Estrutural ficou com o Banco do Brasil, Itaú e Bradesco, com 523, 518 e 368 ocorrências respectivamente.

Em quarto lugar apareceu o Banco da Amazônia, contando com 351 citações sobre o Capital Estrutural no conjunto de suas demonstrações financeiras. Esse posicionamento foi devido à elaboração de um relatório de sustentabilidade no ano de 2006. Esse relatório apontou 101 citações sobre "Práticas de sustentabilidade e responsabilidade Social" e 69 apontamentos sobre "Práticas de Responsabilidade Social" naquele ano.

Destaque-se que, no ano seguinte, 2007, o Banco da Amazônia não apresentou esse relatório de sustentabilidade. Não houve explicação para que esse fato ocorresse e o único detalhe que despertou atenção em seu Relatório Anual de 2007 foi a mudança do presidente da instituição. Todavia, não se pode afirmar que a não publicação desse informe de sustentabilidade seja devida à troca no comando do banco. Por último, cabe mencionar que o banco cita que elaborava um Balanço Social entre o período compreendido nos anos 2000 a 2005.

A Tabela 3 mostra que houve uma pequena redução de itens evidenciados de 2006 para 2007 de aproximadamente $2 \%$, ou seja, 33 itens. Essa redução pode ser apontada, entre outros fatores, pela diminuição de itens divulgados pelo Banco Bradesco (200 para 154 ocorrências), Banco da Amazônia (214 para 71 ocorrências) e Unibanco (142 para 113 ocorrências).

Um dos itens do CE que apresentou maior número de evidenciação foi "Investimentos e Características em TI”. Esse item explica como as instituições financeiras investem em sistemas de informação cujas características variam desde a busca pela segurança da informação e evitar que fraudes eletrônicas ocorreram desde a instalação de terminais até a facilitação de operações financeiras internacionais por meio da Internet, ferramenta que permite que o cliente / usuário faça suas transações pela rede mundial de computadores.

O Gráfico 3, a seguir, mostra os 10 bancos que mais evidenciaram informações sobre "Investimentos e Características em TI". Novamente, o Banco do Brasil apresenta-se como a maior instituição que evidencia itens, seguido pelos Bancos Bradesco e Itaú. 


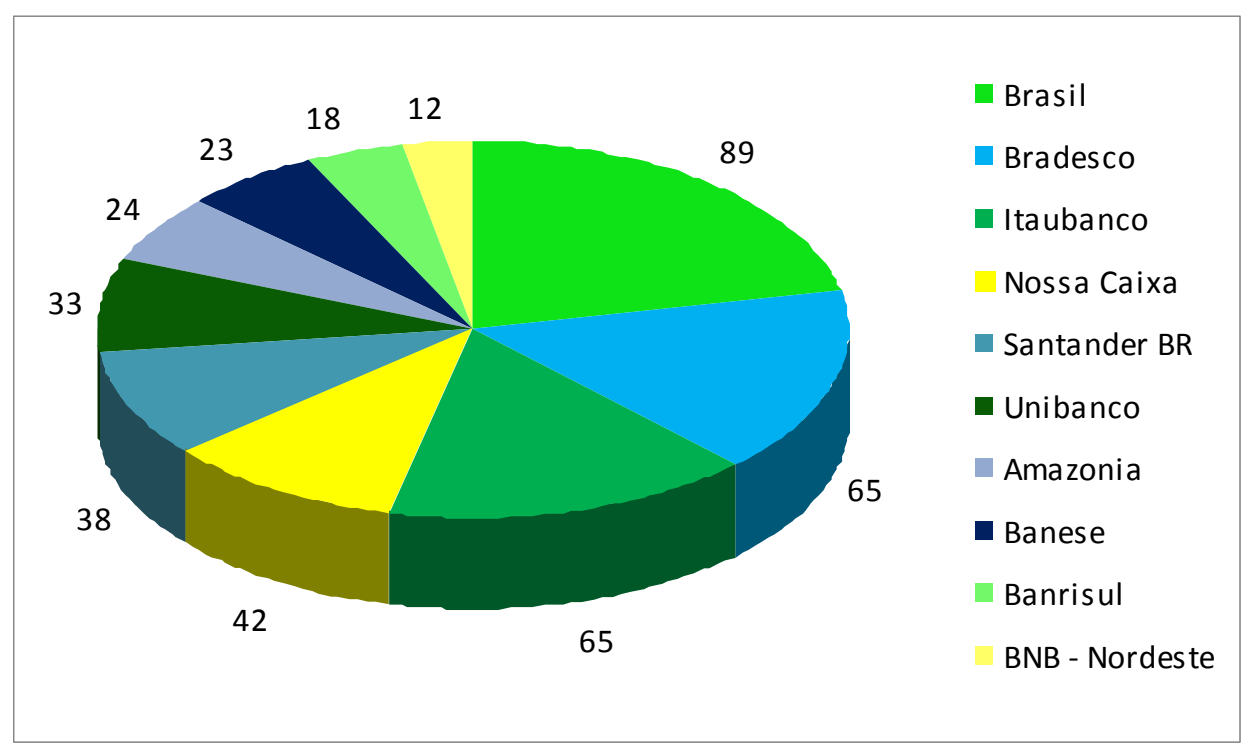

Gráfico 3 - Divulgação de características e investimentos em TI

(2006, 2007 e 1S08)

Outros subitens de fundamental importância são os que se referem a: "Propriedade Intelectual", "Patentes, direitos autorais", "Marcas Corporativas / Brands". Das 28 instituições selecionadas, 23 mencionaram, em algum momento, suas marcas, patentes, endereços de sítio na Internet considerados como ativo.

Dentre elas, destaca-se o Banco Itaú que, em seu relatório de 2007, cita que, pela quinta vez, "a marca Itaú foi considerada a mais valiosa do país, segundo estudo da consultoria internacional Interbrand.” O valor estimado da marca Itaú, em 2007, segundo a própria instituição, equivale a $\mathrm{R}$ \$ 8,1 bilhões.

Outro item do Capital Estrutural de grande importância e muito divulgado pelos bancos foi a "Quantidade e qualidade de canais e agências". Entendem-se como canais os veículos utilizados para a comercialização de produtos bancários e também para que os clientes possam realizar determinadas operações, como saques, depósitos, por meio de caixas eletrônicos, PABs, Postos de Atendimento Bancário, ATM, Automatic Teller Machine, e outros.

O Gráfico 4 evidencia as ocorrências de apontamentos de itens que tratam da quantidade, qualidade de agências e demais canais de venda. Destaca-se o Banco do Brasil, seguindo pelo Bradesco, Nossa Caixa e Unibanco, no ano de 2007. No período de 2006, a instituição que mais se evidenciou foi o Bradesco, seguido por Nossa Caixa e Unibanco respectivamente. Em 
2006, o Bradesco apresentou 28 ocorrências em seu Relatório Anual e, no período seguinte, houve uma queda de 28,6\% na quantidade de informação divulgada. Infere-se que devido à redução no tamanho do Relatório de Administração essas informações podem ter sido impactadas e, dessa forma, reduzidas.

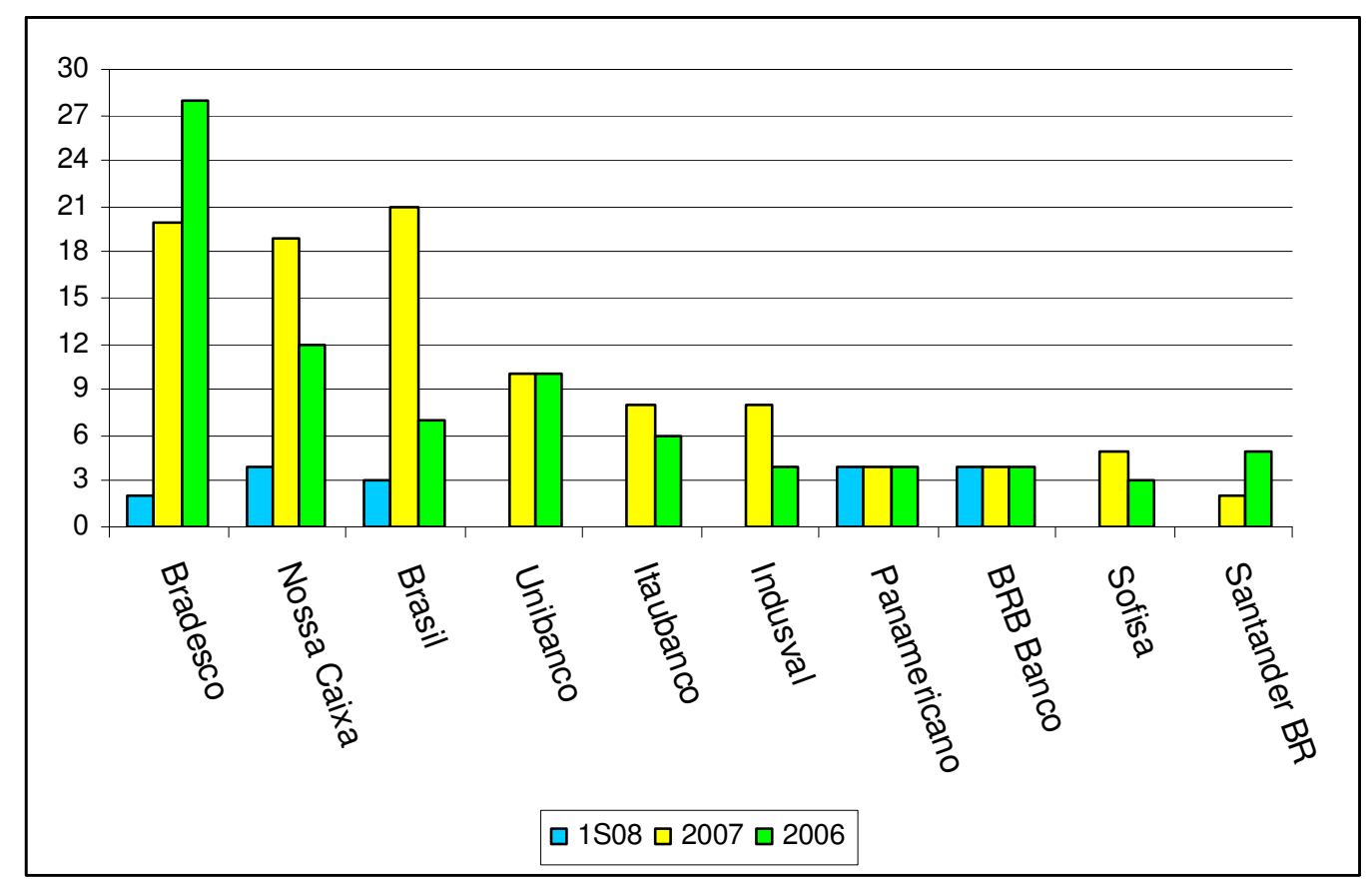

Gráfico 4 - Quantidade e qualidade das agências e demais canais de venda

Os bancos Bradesco, Banco do Brasil, Itaú e Nossa Caixa comentam em seus relatórios que suas agências possuem meios adequados de atendimento aos portadores de deficiência. $\mathrm{O}$ Banco do Brasil, por exemplo, menciona, em seu Relatório de Sustentabilidade, que suas agências possuem $100 \%$ das agências adaptadas para os deficientes.

Em relação à subdivisão "Inovação, pesquisa de produtos financeiros, Pesquisa e Desenvolvimento (P\&D)" poucas foram as instituições que fizeram menção ao item em seus Relatórios de Administração. O banco que mais evidenciou esse tipo de informação foi o Santander, nos períodos de 2006 e 2007. Do total de 181 ocorrências de evidenciação em 2006, o Santander foi responsável por 43 (24\%); em 2007 representou 34,3\% das 140 ocorrências e no 1S08, em que ocorreram somente 06 ocorrências, o Santander foi responsável por 02 ocorrências (as outras 03 ocorrências foram mencionadas pelo BRB Banco e a última pelo Itaú). 
As informações mais típicas evidenciadas pelo Banco Santander quanto ao item "Inovação, pesquisa de produtos financeiros, Pesquisa e Desenvolvimento (P\&D)" foram novos produtos financeiros desenvolvidos, especialmente cartões de crédito e produtos cessão de crédito para os mais diversos públicos, entre eles, os funcionários públicos do Estado de São Paulo, Município do Rio de Janeiro e universitários atendidos pelo Universia, projeto dedicado às questões universitárias patrocinado pelo banco.

O item "Cultura Organizacional”, componente do Capital Estrutural, não pode ser confundido com "Clima Organizacional", que faz parte do Capital Humano. A Tabela 4 exibe as 9 instituições que divulgaram informações sobre Cultura Organizacional. É interessante o fato de o Banco do Brasil, um dos principais divulgadores de informações sobre o Capital Intelectual, aparecer em sexto lugar, estando à frente somente do Banco da Amazônia, Mercantil do Brasil e Banestes.

Tabela 4 - Evidenciação dos itens de Cultura Organizacional

\begin{tabular}{lrrrrrr}
\multicolumn{1}{c}{ BANCO } & 1S08 & 2007 & 2006 & \multicolumn{2}{c}{ Total } \\
\hline Itaubanco & 1 & 15 & 19 & 35 \\
\hline Santander BR & 0 & 17 & 11 & 28 \\
\hline Bradesco & 1 & 9 & 12 & 22 \\
\hline Nossa Caixa & 3 & 9 & 9 & 21 \\
\hline Unibanco & 0 & 10 & 10 & 20 \\
\hline Brasil & 3 & 8 & 8 & 19 \\
\hline Amazonia & 0 & 0 & 2 & 2 \\
\hline Mercantil Brasil & 0 & 1 & 1 & 2 \\
\hline Banestes & 0 & 0 & 1 & 1 \\
\hline Total & 8 & 69 & 73 & 150 \\
\hline
\end{tabular}

Os dois últimos itens ligados ao Capital Estrutural merecem forte ênfase. Trata-se dos itens "Práticas de Responsabilidade Social" e "Práticas de Sustentabilidade e Responsabilidade Ambiental".

Para que haja noção de sua importância, afirma-se que esses dois itens, em conjunto, foram responsáveis por 53\% do total de itens do Capital Estrutural divulgados em 2006, 50\% no ano de 2007 e aproximadamente $61 \%$ no período relativo ao 1S08. A Tabela 5, a seguir, mostra a quantidade os itens evidenciados em todos os períodos analisados: 
Tabela 5 - Responsabilidade social e práticas de sustentabilidade

\begin{tabular}{l|r|r|r}
\hline \multicolumn{1}{c|}{ Evidências nas DCs } & \multicolumn{1}{c|}{$\mathbf{1 S 0 8}$} & \multicolumn{1}{c|}{$\mathbf{2 0 0 7}$} & \multicolumn{1}{c|}{$\mathbf{2 0 0 6}$} \\
\hline Total de itens (Capital Estrutural) & 255 & 1478 & 1511 \\
\hline Responsabilidade social & 104 & 541 & 199 \\
\hline Sustentab./ Resp. Amb. & 51 & 556 & 248 \\
\hline
\end{tabular}

O Banco do Brasil menciona em seu Relatório Anual de 2007 que possui Oficinas de Sustentabilidade e um caderno dentro do report que trata, exclusivamente, da parte de sustentabilidade, contendo 130 páginas. Além disso, foi a única instituição que citou que possui os créditos de carbonos: Carbon Disclosure Project.

O Banco da Amazônia, conforme citado anteriormente, possui diversas informações sobre os itens que patrocina no que tange ao desenvolvimento sustentável da Amazônia. Mesmo com a não publicação do relatório de sustentabilidade em 2007, verifica-se a importância dispensada pela instituição quanto à responsabilidade em colaborar para o desenvolvimento da Região Norte do país.

\subsubsection{Capital de Clientes}

Conforme demonstrado no Quadro 7, os itens que compõem o Capital de Clientes são formados por: "Carteira de Clientes", "Lealdade, fidelidade de Clientes", "Capacitação, Retenção e conquista de Clientes", "Satisfação e Relacionamento Clientes", "Operações estruturadas com Clientes", "Relacionamento com fornecedores e stakeholders", "Investimentos em TI / clientes e Serviços de Internet”, “Treinamento e inovação focada nos Clientes" e "Market Share, participação no mercado".

Como o próprio nome e suas subdivisões sugerem, o Capital de Clientes está ligado, fortemente, com o relacionamento direto entre os bancos e suas carteiras de clientes, além de outras entidades que possuem algum tipo de negociação ou envolvimento com essas instituições.

Partindo da premissa de que o mercado bancário está cada vez mais disputado e que as instituições buscam fidelizar e conquistar o relacionamento direto com seus clientes, o 
tratamento de sua carteira de clientes torna-se fundamental para a ampliação de vendas de produtos e serviços, além da possível ampliação de resultados.

A Tabela 6 mostra a quantidade de itens evidenciados em relação ao Capital de Clientes por todas as instituições no período findo em 2007.

Tabela 6 - Itens de Capital de Clientes divulgados em 2007

\begin{tabular}{|c|c|c|c|c|c|c|c|c|c|c|}
\hline 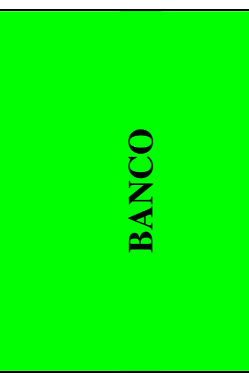 & 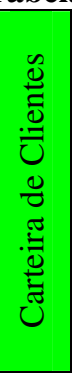 & 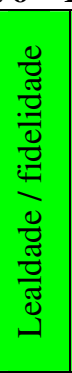 & 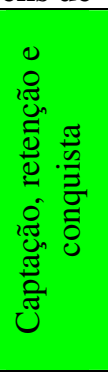 & 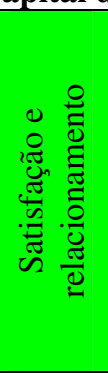 & 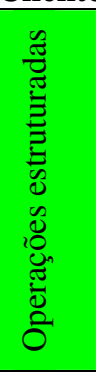 & 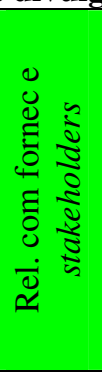 & 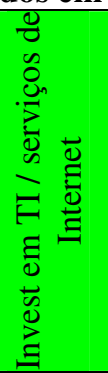 & 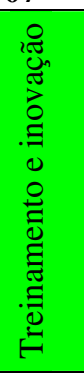 & 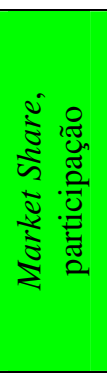 & $\stackrel{\frac{\pi}{0}}{0}$ \\
\hline Santander BR & 5 & 10 & 42 & 28 & 19 & 0 & 8 & 12 & 10 & 134 \\
\hline Itaubanco & 7 & 9 & 11 & 48 & 6 & 23 & 0 & 0 & 10 & 114 \\
\hline Brasil & 12 & 14 & 6 & 2 & 14 & 42 & 6 & 2 & 10 & 108 \\
\hline Sofisa & 16 & 18 & 4 & 10 & 0 & 3 & 0 & 0 & 0 & 51 \\
\hline Unibanco & 14 & 3 & & 4 & 0 & 8 & 1 & & 5 & 35 \\
\hline Nossa Caixa & 12 & 10 & 3 & 2 & 0 & 0 & 0 & 0 & 2 & 29 \\
\hline BNB - Nordeste & 4 & 3 & 4 & 2 & 3 & 6 & 0 & 0 & 0 & 22 \\
\hline Bradesco & 8 & 3 & 0 & 0 & 0 & 6 & 0 & 0 & 4 & 21 \\
\hline ABC Brasil & 1 & 0 & 0 & 0 & 10 & 0 & 0 & 0 & 0 & 11 \\
\hline Pine & 0 & 3 & 0 & 1 & 0 & 2 & 0 & 0 & 0 & 6 \\
\hline Daycoval & 3 & 0 & 0 & 2 & 0 & 0 & 0 & 0 & 0 & 5 \\
\hline Banrisul & 3 & 0 & 0 & 0 & 0 & 1 & 0 & 0 & 1 & 5 \\
\hline Patagonia & 2 & 0 & 0 & 0 & 0 & 0 & 0 & 0 & 2 & 4 \\
\hline BicBanco & 0 & 0 & 0 & 0 & 0 & 2 & 0 & 0 & 2 & 4 \\
\hline Mercantil Brasil & 3 & 0 & 0 & 0 & 0 & 0 & 0 & 0 & 0 & 3 \\
\hline Banese & 2 & 0 & 0 & 0 & 0 & 0 & 0 & 0 & 1 & 3 \\
\hline Panamericano & 2 & 0 & 1 & 0 & 0 & 0 & 0 & 0 & 0 & 3 \\
\hline Est Piaui (BEP) & 0 & 0 & 0 & 0 & 0 & 2 & 0 & 0 & 1 & 3 \\
\hline Cruzeiro do Sul & 1 & 0 & 0 & 0 & 0 & 1 & 0 & 0 & 0 & 2 \\
\hline Parana & 1 & 0 & 0 & 0 & 0 & 0 & 0 & 0 & 1 & 2 \\
\hline Amazonia & 0 & 0 & 0 & 0 & 0 & 0 & 0 & 0 & 2 & 2 \\
\hline Alfa Invest & 1 & 0 & 0 & 0 & 0 & 0 & 0 & 0 & 0 & 1 \\
\hline Banestes & 0 & 0 & 0 & 0 & 0 & 0 & 0 & 0 & 1 & 1 \\
\hline BESC & 0 & 0 & 0 & 0 & 0 & 0 & 0 & 0 & 0 & $\mathbf{0}$ \\
\hline Banpara & 0 & 0 & 0 & 0 & 0 & 0 & 0 & 0 & 0 & $\mathbf{0}$ \\
\hline Indusval & 0 & 0 & 0 & 0 & 0 & 0 & 0 & 0 & 0 & $\mathbf{0}$ \\
\hline Merc Invest & 0 & 0 & 0 & 0 & 0 & 0 & 0 & 0 & 0 & $\mathbf{0}$ \\
\hline BRB Banco & 0 & 0 & 0 & 0 & 0 & 0 & 0 & 0 & 0 & $\mathbf{0}$ \\
\hline Total & 97 & 73 & 71 & 99 & 52 & 96 & 15 & 14 & 52 & 569 \\
\hline
\end{tabular}


Note-se que 5 dos 28 bancos analisados não apresentaram nenhum dado quanto ao Capital de Clientes no ano de 2007. Essas instituições são: BESC (Banco do Estado de Santa Catarina), Banpará, Banco Indusval, Banco Mercantil de Investimentos e BRB Banco. Seus relatórios anuais resumidos, sem uma forma disclosure ampla sobre determinadas informações quanto ao relacionamento com seus respectivos clientes.

O ranking de divulgação dos itens de Capital de Clientes teve o Banco Santander como líder (134 ocorrências), seguido pelo Banco Itaú (114 ocorrências) e Banco do Brasil (108). Essas três instituições em conjunto representam, aproximadamente, $63 \%$ das ocorrências de itens que remetem ao Capital de Clientes no período analisado.

O Banco Santander cita, diversas vezes em seu relatório anual de 2007, o forte relacionamento que possui com seus clientes e também seus possíveis futuros clientes. A instituição dá ênfase em seus reports aos funcionários públicos, aos patrocínios concedidos, produtos e promoções lançadas exclusivamente para esse nicho de mercado.

Esse foco pode ser explicado pelo fato de o Banco Santander ter comprado o Banco do Estado de São Paulo, BANESPA, instituição financeira pública que foi privatizada em 2001. Com o BANESPA tornando-se banco privado, o conglomerado Santander, no Brasil, perdeu a exclusividade de ser o banco pagador da folha de pagamento de funcionários e prestadores de serviço do Estado de São Paulo. Essa perda acarretou uma agressiva campanha para retenção desses clientes para que o banco não permitisse que as receitas caíssem drasticamente.

As afirmações acima podem ser corroboradas pela quantidade de itens evidenciados em relação à "Capacitação, Retenção e Conquista de Clientes”. De um total de 71 das citações em 2007, o Banco Santander foi responsável por 59\% de itens divulgados.

O Itaú, segundo lugar do ranking, também, evidencia inúmeros itens sobre os componentes do Capital de Clientes. O banco menciona a diversidade de clientes que vão desde os correntistas pessoas físicas até as instituições consideradas globais e cuja responsabilidade de relacionamento é feita por seu banco de atacado, o Itaú BBA. Essas operações de atacado correspondem às entidades que negociam grande soma de valores e, geralmente, realizam operações com grande prazo de liquidação. 
O Banco do Brasil que liderava a lista de itens evidenciados quanto ao Capital Humano e Capital Estrutural, ficou em terceiro lugar, bem próximo ao Banco Itaú com uma diferença de 06 evidenciações. Foram poucas as instituições que divulgaram itens sobre "Relações com fornecedores e stakeholders" e o Banco do Brasil foi a entidade que mais mencionou esse tipo de relacionamento, sendo responsável por $44 \%$ das 96 ocorrências nas demonstrações financeiras.

Como principais fornecedores e stakeholders, o Banco do Brasil cita as relações que tem com os diversos agentes do Governo Federal. Além disso, o banco segue a AccountAbility 1000, AA1000, uma norma internacional que orienta a construção de relacionamentos sustentáveis com públicos estratégicos e é reconhecida como prática de excelência corporativa pelos Índices Mundiais de Sustentabilidade da bolsa de valores norte-americana Dow Jones, (DJSI), pela Global Reporting Initiative (GRI) e por outros ratings e rankings de âmbito mundial.

Apesar de não figurar como uma das principais instituições que divulgaram itens do Capital Intelectual e, especialmente do Capital de Clientes, o Banco do Estado do Piauí, BEP, comenta, em seus relatórios, que é o banco que possui maior número de municípios atendidos por correspondência bancária. Esse número era de 156 em 2006 e saltou para 165 em 2007 não ocorrendo informações sobre esse fato no $1 \mathrm{~S} 08$.

Um destaque importante é o Banco Sofisa que, considerado como instituição financeira de pequeno porte, ficou em quarto lugar no ano de 2007 em relação à divulgação do Capital de Clientes em suas demonstrações financeiras.

Verifica-se que a instituição Sofisa foi a maior divulgadora de subitens como a Carteira de Clientes, estando à frente de instituições como Banco do Brasil, Itaú, Bradesco, Santander e Unibanco. Infere-se, dessa forma, a grande preocupação do banco Sofisa em mencionar seus clientes, vistos como um importante meio de continuidade de seus negócios como, também, uma maneira de angariar novos membros para sua clientela.

Para finalizar a análise da evidenciação do Capital de Clientes, cita-se que essa divisão que apresentou o menor número de evidenciações de itens. Em 2006, o Capital de Clientes representava $23 \%$ dos itens divulgados, caindo para 19\% em 2007 e $10 \%$ em 1S08. Mais uma 
vez, afirma-se que não é possível fazer grandes inferências no que tange ao período de 1S08, pois não houve publicação de Relatórios de Administração pelos bancos analisados.

\subsection{Bancos atuantes na Espanha}

Após realizadas as análises dos dados das instituições financeiras atuantes no Brasil, cabe a verificação de como o Capital Intelectual é definido pelas instituições que operam na Espanha, quais itens são evidenciados de maneira voluntária e/ou obrigatória. Conforme citado no item 3.4.2, a população selecionada para a presente dissertação totalizou 9 bancos.

A Tabela 7 mostra a quantidade total de frequências do Capital Intelectual que foram encontradas nos relatórios anuais e demais demonstrações contábeis e reports dos bancos atuantes na Espanha para o período selecionado.

Tabela 7 - Distribuição de ocorrência do CI nos bancos na Espanha

\begin{tabular}{|lrrrrr}
\hline \multicolumn{1}{c}{ Banco } & C. Humano & Cap. Estrut. & Cap. Clientes & Total \\
\hline BBVA & 201 & 578 & 230 & 1009 \\
\hline Santander & 207 & 428 & 173 & 808 \\
\hline Banco de Chile & 118 & 300 & 71 & 489 \\
\hline Sabadell & 35 & 357 & 52 & 444 \\
\hline Bankinter & 91 & 177 & 60 & 328 \\
\hline Guipuzcoano & 30 & 163 & 29 & 222 \\
\hline Pastor & 30 & 126 & 65 & 221 \\
\hline Popular Español & 25 & 96 & 29 & 150 \\
\hline Valencia & 33 & 58 & 17 & 108 \\
\hline Total & $\mathbf{7 7 0}$ & $\mathbf{2 2 8 3}$ & $\mathbf{7 2 6}$ & $\mathbf{3 7 7 9}$ \\
\hline
\end{tabular}

Verifica-se o Banco Bilbao Vizcaya Argentaria, BBVA, como instituição que apresentou o maior número de evidenciações de Capital Intelectual nos períodos analisados. O BBVA apenas não liderou a evidenciação do item Capital Humano, em que o Banco Santander, segunda maior instituição bancária em termos de evidenciação do Capital Intelectual, obteve o maior número de frequências, ultrapassando o primeiro colocado em 06 ocorrências nessa divisão. 
O Gráfico 5 permite a visualização analítica dos itens evidenciados para cada subdivisão do Capital Intelectual pelos 9 bancos atuantes na Espanha. Destaque para o Banco Sabadell que possui muitas frequências de Capital Estrutural ante as evidenciações de Capital Humano e Capital de Clientes em suas demonstrações contábeis e demais relatórios financeiros.

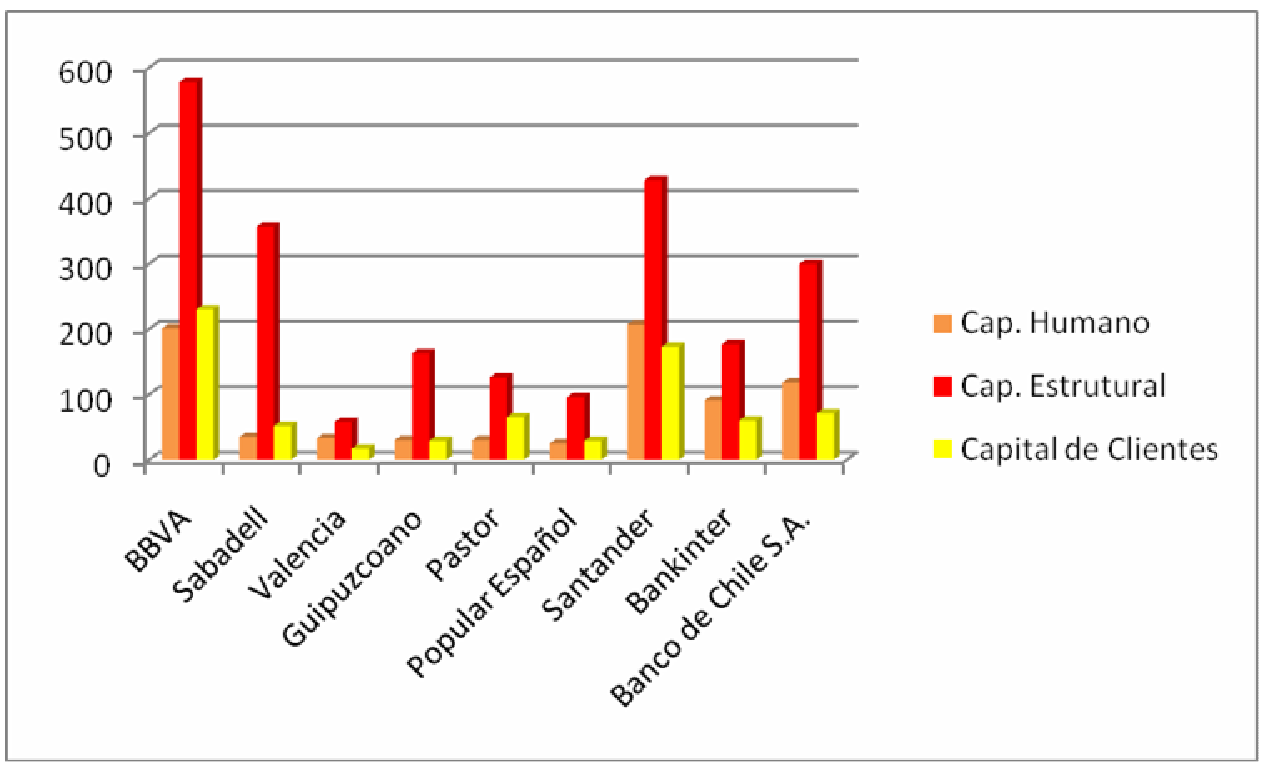

Gráfico 5 - Ocorrência do CI nos bancos na Espanha (2006 a IS08)

\subsubsection{Capital Humano}

Os bancos que atuam na Espanha divulgaram 365 itens relativos ao Capital Humano em 2006 e apresentaram um pequeno aumento no número de ocorrência na ordem de $4 \%$, atingindo, dessa forma, um total de 381 itens no período seguinte.

No primeiro semestre de 2008 ocorreu apenas a divulgação de 24 itens. Assim como acontece no Brasil, as instituições financeiras que desenvolvem suas operações na Bolsa espanhola não publicam relatórios de administração ou outros semelhantes que contenham quantidades significativas de itens ligados ao Capital Intelectual. Isso pode ser provado pela forte redução de ocorrências em todas as divisões do CI.

A subdivisão que apresenta o menor número de ocorrências em todos os períodos é o de "Colaboradores contratados como ativo da empresa". Em 2006, foram destacadas 12 ocorrências (aproximadamente 3\% de itens do Capital Humano); em 2007, ocorreram, 
também, 12 ocorrências, totalizando $3 \%$. No primeiro semestre de 2008, foram encontradas 4 ocorrências, sendo que duas dentro dos relatórios do BBVA, uma nos informes do Banco Santander e a última pelo Banco do Chile.

A Tabela 8 mostra que somente 6 das instituições analisadas evidenciaram itens sobre "Incentivo, adoção e implementação a novas ideias". Esse item é de extrema importância, pois, mesmo que não haja grande número de ocorrências, mostra que o banco institucionaliza a ideia de que todos podem e devem participar para trazer novas ideias e outros meios que contribuam para o crescimento da instituição.

\begin{tabular}{|c|c|c|}
\hline Banco & 2007 & 2006 \\
\hline BBVA & 4 & 3 \\
\hline Santander & 3 & 3 \\
\hline Bankinter & 2 & 2 \\
\hline Banco de Chile S.A. & 2 & 2 \\
\hline Pastor & 1 & 1 \\
\hline Guipuzcoano & 1 & 0 \\
\hline TOTAL & 13 & 11 \\
\hline
\end{tabular}

O item "Investimento em educação especializada e/ou internacional", também, é muito evidenciado pelas instituições espanholas. Essas informações são citadas no Relatório Anual como um importante investimento feito para o desenvolvimento de talentos que a instituição possui.

Os bancos Santander e BBVA são os que mais citam itens sobre investimentos em educação. Por sua vez, o Banco Santander, assim como faz no Brasil, menciona seu programa de recursos humanos denominado "Nuevos Directivos", no qual alguns colaboradores, segundo mérito e potencialidade de crescimento, são expatriados com o intuito de enriquecer a cultura organizacional e adicionar novos valores ao conglomerado financeiro. O BBVA, também, cita em seus relatórios financeiros que expatria alguns funcionários, mas não dá maiores detalhes sobre o destino e qual a finalidade desse programa.

Outras ocorrências referentes ao Capital Humano, como "Política de Retenção e Captação de Talentos", "Nível de Escolaridade" e "Números de funcionários gerentes e gestores", não são tão explicitadas e evidenciadas como nos relatórios dos bancos no Brasil. De qualquer forma, 
reforça-se a ideia de que o número de itens evidenciados não implica na qualidade de informação ou na atuação da instituição. $\mathrm{O}$ fato de os bancos espanhóis não divulgarem mais itens que os bancos brasileiros sobre "Política de Retenção e Captação de Talentos" não pode induzir à ideia de que as instituições espanholas invistam menos do que as brasileiras na retenção de colaboradores.

A Tabela 9 mostra a quantidade de itens evidenciados pelos bancos atuantes na Espanha quanto aos itens de "Nível de Escolaridade", "Número de Funcionários e Gestores" e "Turnover".

Tabela 9 - Divulgação do CH em 2007

\begin{tabular}{l|r|r|rr}
\hline \multicolumn{1}{|c|}{ BANCO } & $\begin{array}{c}\text { Nível de } \\
\text { Escolaridade }\end{array}$ & $\begin{array}{c}\text { Num. de func. } \\
\text { gerentes e } \\
\text { gestores }\end{array}$ & Turnover & TOTAL \\
\hline BBVA & 11 & 12 & 3 & 26 \\
\hline Sabadell & 0 & 2 & 1 & 3 \\
\hline Valencia & 1 & 2 & 0 & 3 \\
\hline Guipuzcoano & 2 & 1 & 0 & 3 \\
\hline Pastor & 1 & 1 & 1 & 3 \\
\hline Popular Español & 2 & 2 & 0 & 4 \\
\hline Santander & 11 & 11 & 5 & 27 \\
\hline Bankinter & 4 & 4 & 2 & 10 \\
\hline Banco de Chile S.A. & 5 & 5 & 2 & 12 \\
\hline \multicolumn{1}{c}{ TOTAL } & $\mathbf{3 7}$ & $\mathbf{4 0}$ & $\mathbf{1 4}$ & $\mathbf{9 1}$ \\
\hline
\end{tabular}

Novamente, a liderança entre os itens evidenciados é demonstrada pelas posições ocupadas pelos bancos Santander e BBVA, respectivamente. Infere-se que o tamanho do banco influi, significativamente, na quantidade de informações divulgadas nos relatórios anuais e demais relatórios financeiros.

O estudo de El-Bannany (2008) em bancos do Reino Unido corrobora a assertiva acima. O autor afirma, em seu trabalho, no qual são estudadas as determinantes do Capital Intelectual nos bancos do Reino Unido, que o papel potencial do Capital Humano e de sua divulgação em bancos grandes é esperado para ser mais claro e em maior quantidade do que outros bancos de médio ou pequeno porte.

Em terceiro lugar no ranking de divulgação de itens do $\mathrm{CH}$, a presença do Banco de Chile. Especificamente, esse banco divulga que investe, pesadamente, na formação contínua de seus 
colaboradores e tem em seu quadro aproximadamente 5\% de seus funcionários com curso de doutorado em 2007 (em 2006 o percentual informado era o mesmo).

O Bankinter, quarto colocado, apresenta informações adicionais quanto ao número de funcionários que ocupam cargo de gerência ou chefia como, por exemplo, a divisão por sexo dos cargos de confiança ocupados. Em seu relatório de 2006, o banco possuía 38\% dos cargos de confiança ocupados por mulheres. Já em 2007, esse percentual subiu para 40\%. Além do Bankinter, Santander, BBVA, Banco de Chile e Banco de Sabadell divulgam tais informações.

O item "Benefícios (além dos exigidos por lei)" é o que apresenta maior divulgação nos anos de 2006 e 2007. Em 2006, esse subitem representava 26\% de toda a evidenciação do Capital Humano nos bancos atuantes na Espanha, enquanto, em 2007, esse índice era de 22\%. Em 1S08 só foram divulgados 24 itens sobre o Capital Humano sendo que o item Benefícios representava $8 \%$ (2 ocorrências).

Os maiores destaques de benefícios oferecidos dão-se pelos planos de previdência privada como também oportunidades de lazer para os colaboradores e seus familiares. Os bancos que mais citaram os familiares como beneficiários de lazer oferecidos pela instituição foram Banco BBVA, Santander, Banco de Chile, Guipuzcoano e Bankinter.

A subdivisão do Capital Humano "Clima Organizacional" incorreu em 73 ocorrências em 2007 (60 em 2006). O Gráfico 6, a seguir, mostra as instituições que mais divulgaram ocorrências sobre esse item. 


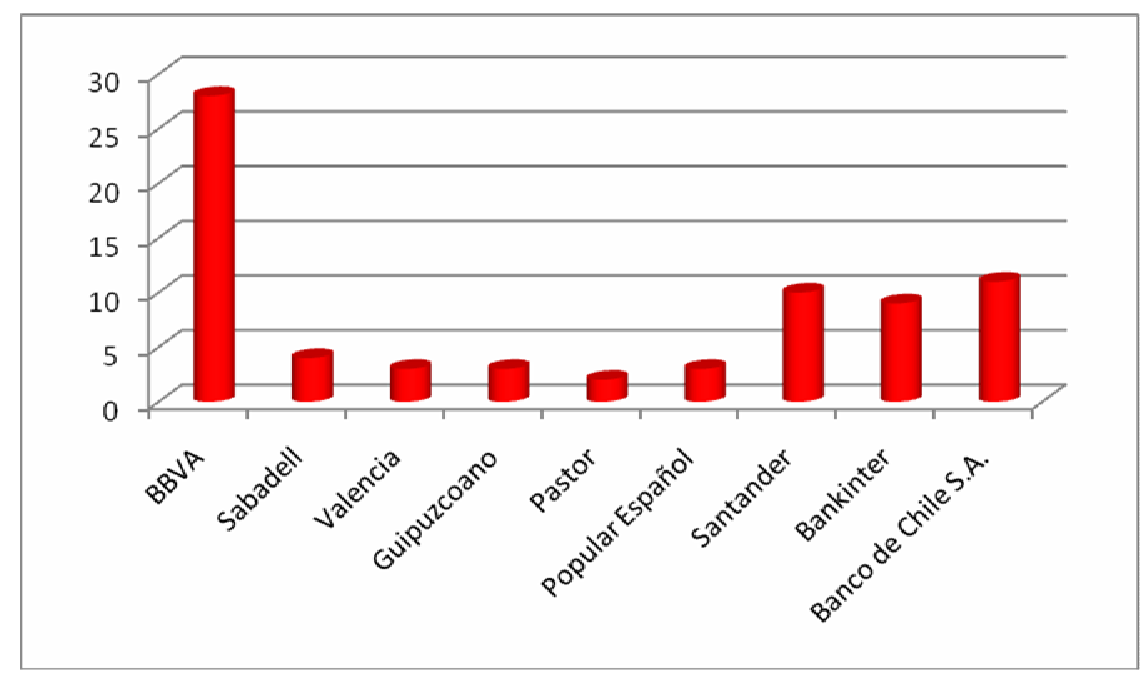

Gráfico 6 - Evidenciação do item Clima Organizacional em 2007

\subsubsection{Capital Estrutural}

Nos períodos de 2006 e 2007, a subdivisão Capital Estrutural correspondia a 61\% (1.075 e 1.141 ocorrências respectivamente) de todos os itens evidenciados do Capital Intelectual. Em 1S08, o Capital Estrutural alcançava 55\% dos itens evidenciados (67 ocorrências) do CI.

Em 2007, a instituição que mais evidenciou itens foi o BBVA com 294 ocorrências, seguido pelo Banco Santander (208 ocorrências), Banco Sabadell (183 ocorrências) e Banco de Chile (142 ocorrências).

Os bancos que apresentaram a menor quantidade de informações foram o Banco de Valencia (28 itens evidenciados), Banco Popular Español (50 itens), Banco Guipuzcoano (79 itens) e Bankinter (88 itens).

Levando-se em consideração o período de 2007, os itens que mais foram evidenciados foram: os ligados à quantidade e qualidade de canais e agências (421 ocorrências - 37\%); "Práticas de Responsabilidade Social" (197 ocorrências - 17\%); "Práticas de Sustentabilidade e Responsabilidade Ambiental" (153 ocorrências - 13\%); "Características e Investimentos em Tecnologia da Informação" (138 ocorrências - 12\%).

Quanto à "quantidade e qualidade de canais e agências", os bancos citavam, principalmente, a quantidade de pontos de venda e onde estavam localizados. Destaque-se o fato de que vários 
bancos transnacionais (Santander, BBVA, Pastor, Banco de Chile e Guipuzcoano) citarem os pontos de venda em outras jurisdições.

O BBVA foi a instituição que mais detalhou as agências e demais pontos de vendas em outros países totalizando $29 \%$ de todas as ocorrências desse subitem. O banco cita, em seu relatório, a função de cada ponto de venda, a concentração na região de Madri, além de outras informações em relação à quantidade média de colaboradores em cada agência etc..

Houve o cuidado de diferenciar, para a presente pesquisa, as ocorrências que tratavam, especificamente, de canais de venda em relação àqueles que mencionavam a presença em outros territórios das instituições financeiras para que não houvesse contagem incorreta dos subitens em questão.

A subdivisão "Cultura Organizacional", que trata do clima e costumes institucionalizados das organizações, também, apresenta importante destaque nas evidenciações do Capital Estrutural dos bancos atuantes na Espanha. As instituições que mais divulgaram subitens concernentes ao tema em 2007 foram: o Banco Santander e BBVA (com 32 ocorrências cada um); Bankinter (15 ocorrências) e Sabadell (14 ocorrências). O Banco Pastor apresentou apenas uma ocorrência, sendo a instituição que menos mostrou a Cultura Organizacional como Capital Intelectual em seus reports. Com poucas evidenciações, aparecem, também, o Banco Guipuzcoano (02 ocorrências) e o Banco de Valencia (03 ocorrências).

Os subitens "Patentes, Direitos Autorais", "Marcas Corporativas / Brands" e "Propriedade Intelectual" foram os que menos apresentaram ocorrências de evidenciações. Mais uma vez, os bancos Santander e BBVA empataram com 09 ocorrências sobre "Propriedade Intelectual" cada um em 2007. Sobre "Patentes e Direitos Autorais" quatro instituições não divulgaram nenhum tipo de informações, sendo elas: Banco de Sabadell, Banco Guipuzcoano, Banco Pastor e Popular Español.

\subsubsection{Capital de Clientes}

Conforme citado no item 4.2.3, o grupo Capital de Clientes foi a divisão do Capital Intelectual que menos apresentou itens evidenciados pelos bancos atuantes no Brasil. Esse fato, igualmente, é percebido nos bancos espanhóis nos períodos de 2006 e 2007, nos quais o 
Capital de Clientes totalizou 19\% de itens concernentes ao CI. No período de 1S08, esse percentual equivalia a $26 \%$ do total evidenciado, mas o período apresenta baixa quantidade de ocorrências.

Em 2006, houve a ocorrência de 337 itens do Capital de Clientes nos bancos na Espanha. Em 2007, foi percebido um acréscimo de aproximadamente $6 \%$, totalizando, dessa forma, 357 ocorrências. Em 1S08, ocorreram apenas 32 citações diretas ou indiretas quanto ao Capital de Clientes.

Assim como ocorrido nas outras divisões do CI, os maiores bancos espanhóis, BBVA e Banco Santander, lideraram a evidenciação desses itens. Coube ao BBVA a maior quantidade de itens divulgados em seus relatórios nos três períodos analisados. Em 2006, o banco apresentou 112 ocorrências de CC, caindo para 103 em 2007 e apresentando apenas 15 em $1 \mathrm{~S} 08$.

O item que apresenta a maior evidenciação, dentro da divisão Capital de Clientes, é o "Relacionamento com fornecedores e stakeholders". Essa subdivisão apresentou uma média de $27 \%$ do total de itens evidenciados em 2006 e 2007. Destaque-se que houve, também, a ocorrência de apenas 4 evidenciações desse item, um total de 32 do CC em 1S08.

Os bancos citam seus parceiros comerciais e até outras instituições bancárias que realizam operações financeiras em conjunto como exemplos de fornecedores e stakeholders. Esses parceiros comerciais são muito mencionados em relação às operações de financiamentos de obras de longo prazo financiadas pelos bancos em seu segmento de atacado.

O segundo item mais citado do CC foi “Operações estruturadas com Clientes". Geralmente, trata-se, também, de operações de atacado que envolvem grandes quantias de valores e os bancos inserem o nome do cliente ou clientes envolvidos além do valor negociado e/ou emprestado. Em 2006, foram encontradas 58 ocorrências sobre operações estruturadas e o BBVA respondia por 50 citações, ou seja, $86 \%$ do total. Em 2007, o total de ocorrências cai para 46 , em que o BBVA representa $80 \%$ do total.

Nos períodos de 2006 e 2007, o Banco Santander apresentou apenas 4 ocorrências e o Banco Pastor 2 ocorrências em cada ano. Em 1S08, não foi citada nenhuma ocorrência para nenhum 
dos bancos pesquisados. É provável que operações estruturadas tenham ocorrido nesse período, mas há divulgação sobre elas somente quando do fechamento dos relatórios anuais, segundo conclusão que pode ser feita por meio da análise dos três períodos pesquisados.

As ocorrências que menos apresentaram evidenciações foram: "Investimentos em TI / Clientes e Serviços de Internet" e “Treinamento e Inovação focada nos Clientes”. Assim como no Brasil, há poucos itens evidenciados sobre esses temas.

O item "Satisfação e Relacionamento com Clientes", igualmente, foi citado por quase todos os bancos pesquisados. O Gráfico 7 mostra as instituições e a quantidade de ocorrências desse item no ano de 2007. Cabe destacar que o único banco que não apresentou nenhuma referência a esse item foi o Banco Guipuzcoano.

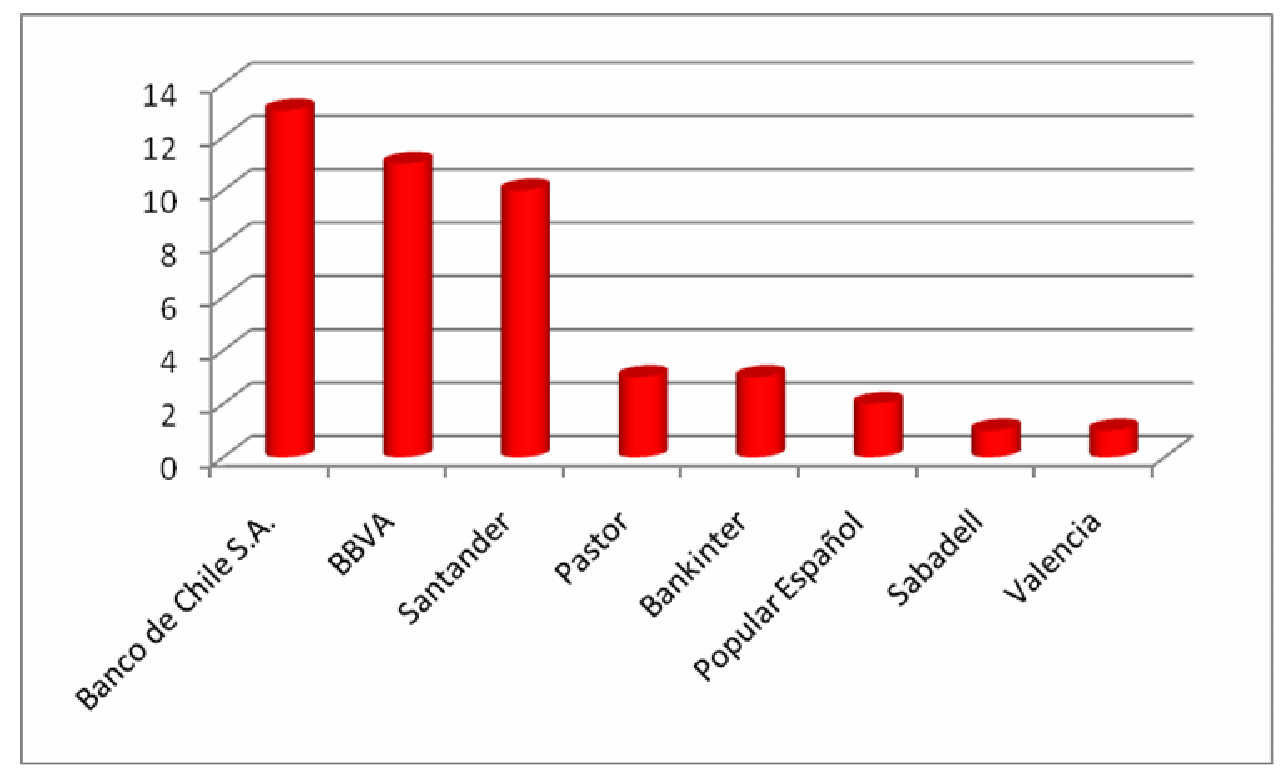

Gráfico 7 - Satisfação e relacionamento com clientes em 2007

O item "Captação, Retenção e Conquista de Clientes", também, aparece nos relatórios dos bancos. Esse item é importante porque mostra a forma como a instituição busca manter e ampliar sua carteira. O Banco de Chile liderou na divulgação desses itens nos três períodos analisados, seguido pelo Santander e BBVA respectivamente.

Quanto ao "Market Share participação no Mercado", todos os bancos apresentaram citações. Novamente, Santander, BBVA e Banco de Chile foram as instituições que mais evidenciaram esse subitem. Destaque ao Banco Santander que se intitulou "Maior Banco do Mundo" em 
2006, tendo como base pesquisa realizada pela revista Euromoney de 2005. O BBVA, por sua vez, intitula-se o maior banco da Europa em 2006 pelo ROE, Return on Equity, obtido naquele ano. 


\section{CONCLUSÃO}

\subsection{Apresentação dos resultados}

Após ter-se realizado a análise das divisões do Capital Intelectual divulgadas pelos bancos cotizantes no Brasil e Espanha, cabe elencar um tópico que condense as informações obtidas para que sejam respondidos os objetivos desta pesquisa.

Dessa forma, empregou-se a sequência utilizada por Antunes (2004, p. 177), em sua tese de doutorado, para objetivar as respostas e considerações encontradas aos itens evidenciados do CI.

\subsubsection{Do Objetivo 1}

Conforme o item 1.2.2, o Objetivo 1, desta dissertação, é "Verificar os conceitos de Capital Intelectual utilizados pelos bancos brasileiros e espanhóis em suas demonstrações financeiras".

Conforme discorrido ao longo do Capítulo 4, tanto os bancos brasileiros como os bancos espanhóis apresentam o conceito de Capital Intelectual, principalmente, em seus relatórios anuais e relatórios de administração. Nenhuma alusão ao termo foi encontrada nas demonstrações contábeis tradicionais de nenhum dos países. Foi encontrada, no Balanço Patrimonial e nas Notas Explicativas, a citação da criação de um subgrupo Ativo Intangível dentro do Ativo Permanente.

No Brasil, as instituições que divulgaram maior número de informações foram as que apresentaram o conceito de Capital Intelectual em seus relatórios. O Banco do Brasil não define, explicitamente, o CI, mas evidencia, em seu RA, uma seção para tratar, exclusivamente, dos Ativos Intangíveis, divididos, por sua vez, em: Marca, Recursos Humanos e Tecnologia da Informação. 
O Banco Itaú apresenta, em seu Relatório de Sustentabilidade de 2007, uma seção denominada Ativos Intangíveis que contempla três subseções. Essa divisão é dada por: Marca, Capital Intelectual e Capital Tecnológico. O banco não formaliza uma definição para o CI e apenas cita que possui uma sólida história de valorização de seu CI, incentivando a formação ética e profissional de seus funcionários. Os itens concernentes ao Capital Tecnológico e Marca tratam das subdivisões próximas às adotadas nesta pesquisa para o Capital Estrutural, além de conter, em outras áreas do relatório, itens ligados à responsabilidade social, ambiental etc..

O Banco Bradesco, também, não conceitua o CI nas demonstrações contábeis, mas possui uma área em seu Relatório de Administração que trata dos Ativos Intangíveis, divididos em: Marca, Recursos Humanos e Tecnologia da Informação. O banco cita na página 47, do Relatório Anual de 2007, que: "O valor de Mercado do Bradesco, com base na cotação de suas ações na Bolsa de Valores no encerramento do ano, alcançou R\$ 109,463 bilhões e equivale a 3,61 vezes o Patrimônio Líquido contábil, que era de $R \$ 30,357$ bilhões. Essa expressiva diferença resulta da magnitude dos ativos intangíveis, os quais, embora não refletidos nas contas de balanço, são percebidos e avaliados pelos investidores."

Essa afirmação dada pelo Bradesco vai de encontro à ideia do Capital Intelectual tido como diferença entre o valor contábil e valor de mercado da entidade de Edvinsson e Malone (1998), mesmo não citando diretamente o termo CI.

O Banco Santander Brasil não define o CI, mas informa em seu RA de 2007, página 40, que mantém vários ativos intangíveis que se integram e agregam valor a clientes, acionistas, colaboradores e comunidade. Informa, ainda, que a soma desses intangíveis fez com que o banco atingisse, em 2007, a conquista de 1 milhão de novos clientes.

Os demais bancos, atuantes no Brasil, fazem, em sua grande parte, alusão ao CI de maneira indireta, por meio do Ativo Intangível como os 04 exemplos citados, porém não citaram em extensão itens ou menções que levassem à definição do Capital Intelectual.

Por sua vez, os bancos espanhóis apresentam, também, uma conceituação indireta do Capital Intelectual em seus relatórios anuais por meio dos ativos intangíveis. O BBVA trata o CI em seção apartada das demais informações econômico-financeiras. Em seu RA de 2006, o banco 
define que seus ativos intangíveis se agrupam em três grupos distintos: aqueles que se referem ao conhecimento das pessoas que trabalham na organização (Capital Humano); os conhecimentos vinculados e estruturados, como também os sistemas de informação, comunicação e Cultura Corporativa (Capital Estrutural) e, por último, os itens que mostram a capacidade de relacionamento do banco BBVA com grupos ligados às suas atividades (Capital Relacional).

Essa afirmativa, também, remete à classificação de Edvinsson e Malone (1998), considerando que o Capital Relacionado citado no relatório do Banco seja o mesmo que Capital de Clientes. Há, ainda, a definição de ativo intangível pelo Banco de Valencia em seu relatório anual de 2006. Para eles, os ativos intangíveis são aqueles considerados como ativos não monetários e sem aparência física que surgem por meio de uma transação ou são desenvolvidos internamente pela instituição.

Além disso, a instituição tem o cuidado de mencionar que o reconhecimento contábil de seus ativos intangíveis somente é realizado quando se pode estimar de maneira razoável seu valor e que o banco tenha probabilidade de obter benefícios econômicos futuros com esse ativo. A definição dada pelo Banco de Valencia vai de encontro às definições de Ativo Intangível do IASB, CPC e outros autores mencionados, neste trabalho, ao longo do Capítulo 2.

O BSCH, Banco Santander Central Hispano, controlador do Banco Santander Brasil, também, menciona, em seus relatórios de 2006 e 2007, a definição de ativo intangível e trata, especialmente, do Capital Intelectual, informando que, parte dos resultados angariados pelo banco ao longo de suas operações, é devida ao Capital Intelectual controlado pela instituição em todos os países nos quais atua, assim como ocorrido no Brasil.

Outra instituição que cita o uso e a definição de Capital Intelectual e ativo intangível é o Bankinter. Em seu relatório de 2007, o banco comenta que realiza um importante esforço para gerenciar seus ativos intangíveis, classificados como o talento de seus empregados, sua cultura corporativa e o valor de seu relacionamento com os grupos envolvidos. Por último, a instituição comenta que preza pela medição, comparação e publicação de todos os dados envolvidos nesse processo de evidenciação. 
O Banco de Chile, instituição de origem chilena que cotiza na Bolsa de Madri, possui um relatório específico, dentro de seu relatório anual, denominado "Compromiso Social". Esse relatório de 31 páginas, em 2007, é subdivido em três categorias: "Nossos Colaboradores", "Nossos Clientes" e "Nossa Comunidade". Os itens ligados ao Capital Estrutural estão distribuídos entre os cadernos de "Nossos Clientes" e "Nossa Comunidade".

Verifica-se, dessa forma, que o Capital Intelectual é conceituado, indiretamente, por meio de componentes do Ativo Intangível dentro dos relatórios anuais dos bancos brasileiros e também dos espanhóis. Infere-se que os bancos atuantes nos dois países possuem entendimento de que o Capital Intelectual é um ativo intangível, conforme discutido na literatura, ao longo do Capítulo 2.

\subsubsection{Do Objetivo 2}

O objetivo 2 estabelecido foi "Conhecer o nível de evidenciação do CI nos bancos atuantes no Brasil e na Espanha".

Conhecer o nível de evidenciação consiste, nesta pesquisa, em determinar quais divisões do Capital Intelectual apresentam maiores ou menores quantidades de itens divulgados, quais ocorrências foram mais ou menos frequentes, além de verificar algumas similaridades ou disparidades quanto à informação reportada entre os dois países.

Levando-se em conta a afirmação de Antunes (2004, p. 262) de que os gestores das empresas brasileiras, em sua maioria, associam o Capital Intelectual ao elemento humano, supôs-se que a divisão do Capital Humano apresentaria a maior quantidade de itens evidenciados nas demonstrações financeiras dos bancos.

Todavia, pela quantidade de itens evidenciados, verificou-se, tanto no Brasil quanto na Espanha, a divisão que mais apresentou ocorrências foi o Capital Estrutural em todos os períodos. Destaque-se que a divulgação de itens concernentes ao Capital Estrutural representou, em média, quase 50\% de toda a evidenciação do Capital Intelectual dos bancos. 
A afirmação, feita na Contextualização, página 11, de que os bancos se constituem num emaranhado de sistemas interligados, explica a grande quantidade de itens relativos ao Capital Estrutural divulgados.

Todavia, ainda sobre o Capital Estrutural, as subdivisões que apresentaram maiores ocorrências foram as ligadas às práticas de responsabilidade social e ambiental, sendo que as características ligadas à TI, marcas e patentes ficaram em segundo e terceiro lugares respectivamente.

Quanto aos itens ligados ao Capital Humano e Capital de Clientes, a divulgação de itens dos bancos na Espanha se assemelha ao disclosure dos itens no Brasil. Especificamente em relação ao Capital Humano, os itens mais destacados foram: "Benefícios além dos exigidos por Lei" e "Clima Organizacional". As ocorrências menos frequentes foram: "Colaboradores considerados como ativo da empresa e Incentivo", "Adoção e implementação a novas ideias".

Averiguou-se que o Capital de Clientes possui fortes índices de ocorrências na subdivisão "Relacionamento com fornecedores e stakeholders" e poucas em "Investimentos em TI / Clientes e Serviços de Internet”. Cabe destacar que a Espanha apresentou pouquíssimas ocorrências sobre esse tema, totalizando somente 3 apontamentos em 2006 e 2007 e 1 em $1 \mathrm{~S} 08$.

Como diferenças apontadas entre a forma de divulgação do CI pelos bancos no Brasil e na Espanha, pode-se citar a quantidade de páginas dos relatórios de administração das instituições financeiras de cada um dos países. Enquanto o Brasil possui, em média, RA menores, os bancos espanhóis possuem, aproximadamente, mais de 150 páginas em cada um de seus relatórios. Além disso, os espanhóis detalham muito mais as operações estruturadas do que o Brasil. Não foi checado, porém, se a quantidade de operações estruturadas na Espanha é superior às realizadas Brasil.

\subsubsection{Do Objetivo 3}

O objetivo 3 consistia em "Conhecer os itens do Capital Intelectual que são divulgados de maneira voluntária ou não pelos bancos”. 
De forma objetiva, pode-se afirmar que todos os itens do Capital Intelectual são divulgados de maneira voluntária, pois nenhum órgão regulador brasileiro, espanhol ou internacional obriga ou explana como o CI e seus itens devem ser reconhecidos, mensurados e divulgados nas demonstrações contábeis e até nos relatórios de administração.

Não se pode confundir a obrigatoriedade da divulgação do ativo intangível com o Capital Intelectual. O CI é considerado um ativo intangível, porém tanto o CPC n. 04 quanto a IAS 38 não fazem menção em toda sua extensão sobre o Capital Intelectual em si.

Quanto à Espanha, não foram encontradas na CNMV (2008), Comisión Nacional del Mercado de Valores, órgão que regula as empresas que cotizam na Bolsa de Madri, orientação, instrução ou obrigação quanto à forma de divulgação de itens do Capital Intelectual.

\subsubsection{Do Objetivo 4}

O objetivo 4 consistia em "Verificar se a evidenciação do Capital Intelectual nas instituições financeiras cotizantes nos dois países está se alterando ao longo do tempo".

Pela quantidade reduzida de períodos analisados, não se poder afirmar categoricamente que há crescimento na quantidade de informações divulgadas do Capital Intelectual nos bancos ora estudados, todavia, averiguou-se que há um crescimento nominal em itens evidenciados.

Na Espanha, o crescimento do período de 2006 para 2007 foi de aproximadamente 6\% ou, precisamente, 102 categorias. O Capital de Clientes apresentou incremento de 20 ocorrências no período de 2007, enquanto o Capital Estrutural incorreu em 66 ocorrências e o Capital de Humano apresentou 16 ocorrências.

O Brasil apresentou um crescimento de 98 ocorrências, passando de 2.944 citações em 2006 para 3.042 em 2007. Destaque-se que o Capital de Clientes nos bancos no Brasil caiu de 663 evidenciações para 569 no ano de 2007. O Capital Estrutural apresentou um aumento de 33 ocorrências e o Capital Humano de 225 ocorrências, ou seja, um aumento de aproximadamente $29 \%$ no período analisado.

Para reforçar a ideia de crescimento nos itens evidenciados, pode-se citar o trabalho de Oliveiras e Kasperkaya (2004), que estudaram justamente a evidenciação de ocorrências do 
Capital Intelectual na Espanha entre as 13 maiores companhias no ano 2000. As referidas autoras concluíram que o nível de evidências crescera ao longo do tempo. Como exemplo isolado, Oliveiras e Kasperkaya citaram que o aparecimento do item "Responsabilidade Social", em que foram encontradas 56 frequências, enquanto em 2002, ou seja, dois anos depois, esse número passou para 156 frequências encontradas. Verifica-se que, em 2007, somente o Banco BBVA apresentava 43 frequências sobre Responsabilidade Social, o que evidencia o crescimento da divulgação.

O 1S08 foi desconsiderado para fins de comparabilidade de crescimento, visto que esse período apresenta uma quantidade reduzida de informações divulgadas do CI. Além disso, não poderia ser afirmado que houve uma real diminuição das informações divulgadas, pois não há um relatório de administração ou similar para esse período.

\subsection{Considerações finais}

Partindo da importância do Capital Intelectual utilizado pelas instituições financeiras em suas operações, esta dissertação buscou estudar como o CI, por meio de seus componentes, é divulgado nas demonstrações contábeis, relatórios de administração e demais relatórios financeiros nos bancos atuantes no Brasil e na Espanha.

Averiguou-se por meio da ocorrência de itens relacionados ao Capital Intelectual que os bancos fazem uso constante do CI e o valorizam. Todavia, há carência de mensuração, ou seja, valoração desses itens e, na falta de um modelo específico, as instituições divulgam essas informações de maneira qualitativa em seus relatórios financeiros.

Com o intuito de responder à questão de pesquisa, a literatura clássica quanto à definição do Ativo, Ativo Intangível, goodwill foi visitada e discutida com o intuito de alcançar e verificar como foram construídas as definições e classificações do Capital Intelectual. Além do CI, também, foi brevemente estudada a Sociedade do Conhecimento, "Era" que considera o Capital Intelectual, na figura do conhecimento, como um dos mais importantes ativos para o alcance de um dos principais objetivos das entidades atualmente. Por último, foram revistos 
os principais conceitos e atividades de um banco atual, visto que há muitos trabalhos científicos que tratam desse tema.

As definições de CI foram estudadas e chegou-se à conclusão de que os especialistas sobre o tema consideram sempre os elementos humano, estrutural, tecnológico e de relacionamento com clientes, sociedade e outros interessados como itens constituintes do Capital Intelectual.

Pode-se dizer que as instituições financeiras atuantes, no Brasil e na Espanha, também, relacionam os mesmos itens citados pela literatura clássica ao Capital Intelectual. Os bancos divulgam, em seus relatórios, descrições sobre os elementos humanos, estruturais, socioambientais, relacionados aos clientes como Capital Intelectual ou, muitas vezes, como seção denominada Ativo Intangível.

A comparação entre dois países contribuiu muito para o desenvolvimento do trabalho, pois se acreditava que haveria discrepância entre definições, itens divulgados e qualidades de informação no Brasil e na Espanha. De maneira geral, chegou-se à conclusão que essas diferenças não ocorreram para os períodos estudados e isso pode ser explicado por diversos motivos, seja pela quantidade de informações divulgadas pelos bancos nos dois países, seja pelo fato de não haver normatização ou orientação sobre como tratar o tema do CI por meio dos órgãos reguladores de cada país ou internacionais, pela quantidade de informações que os leitores das demonstrações demandem das instituições, entre outras.

Posteriormente à divisão do Capital Intelectual em Capital Humano, Capital Estrutural e Capital de Clientes, houve o fracionamento em 9 subdivisões para cada grupo do CI com o intuito de se estabelecer um modelo para que fossem procuradas as ocorrências de itens pertinentes nas demonstrações contábeis e, principalmente, nos relatórios anuais ou relatórios de administração.

Assim sendo, chegou-se às seguintes conclusões durante a elaboração da presente dissertação:

- $\quad$ O Capital Intelectual é um Ativo e pode ser considerado como um ativo intangível pelas suas características intrínsecas. 
- O Capital Intelectual apresenta uma série de divisões e subdivisões, mas os elementos humanos, tecnológicos, clientes e demais interessados são considerados sempre em sua definição, seja pela literatura acadêmica seja pelas instituições que reconhecem esses elementos em suas demonstrações.

- $\quad$ Na evidenciação do Capital Intelectual pelos bancos atuantes no Brasil e na Espanha, o termo mais citado para explanar sobre seus componentes é "Ativo Intangível” e não "Capital Intelectual”.

- O grupo Ativo Intangível, em que são citados os itens do CI nos relatórios de administração, não possui relação direta com o Ativo Intangível, subgrupo contábil do Ativo Permanente que faz parte do Balanço Patrimonial.

- Os bancos pesquisados acreditam e informam em seus relatórios que os elementos intangíveis, considerados como Capital Intelectual, contribuem para seu próprio crescimento, desenvolvimento econômico-financeiro, além de se constituírem num facilitador para que possam atingir suas missões e objetivos.

- Há muitas similaridades entre os bancos brasileiros e espanhóis no que tange à divulgação dos itens do Capital Intelectual. Esperava-se que os bancos espanhóis, sendo detentores de uma economia mais estabilizada, mercado de capitais mais desenvolvido e antigo do que o brasileiro, apresentassem maior quantidade e qualidade de informações divulgadas. Tal premissa não foi comprovada e, por meio da análise qualitativa, afirmase que a divulgação dos itens do CI entre os países é muito semelhante.

- $\quad$ Ao contrário do que se esperava, o Capital Humano não foi a divisão que apresentou maior número de ocorrência de divulgação de itens. O elemento humano é muito citado nas demonstrações contábeis, porém o Capital Estrutural foi a classificação em que mais itens foram incorridos pelos bancos dos dois países.

- Ainda em relação ao Capital Estrutural, houve mais ocorrências de itens ligados à Responsabilidade Social, Responsabilidade Ambiental e Práticas de Sustentabilidade do que itens ligados à tecnologia da informação. 
- As instituições mencionam os colaboradores como importante ativo da empresa, porém não conseguem mensurar o valor desse importante ativo, segundo suas próprias descrições.

- Os bancos valorizam, em seus relatórios, os benefícios concedidos aos colaboradores além daqueles exigidos pela lei. Os benefícios mais citados pelos bancos brasileiros são, em grande parte, os planos de previdência privada patrocinados em sua maioria pela instituição. Já os bancos espanhóis, também, citam os planos de previdência, porém dão ênfase aos itens ligados ao lazer e ao bem-estar do colaborador enquanto o período de atividade de suas funções.

- Os bancos espanhóis destacam, em seus relatórios, as operações de atacado, citando as operações realizadas ao longo do tempo, enquanto esse tipo de informação possui menor evidência nos relatórios dos bancos brasileiros.

- As informações divulgadas sobre o CI pelos bancos dos dois países são realizadas de maneira voluntária, ou seja, nenhum órgão regulador, seja nacional ou internacional, apresenta exigências e/ou recomendações sobre o que e de que forma evidenciar.

- Verificou-se que o número de itens divulgados nos períodos anuais cresce nominalmente. Todavia, somente dois períodos anuais, 2006 e 2007, foram comparados e isso implica não se poder afirmar categoricamente que há crescimento ao longo do tempo.

- O 1S08 foi desconsiderado como período para análise do crescimento das informações divulgadas porque não há relatórios de administração ou outros similares que tratem de informações que remetam aos itens do CI.

Resumidamente, pode-se afirmar a real importância do Capital Intelectual nas organizações bancárias abertas brasileiras e espanholas. Os leitores e usuários das demonstrações contábeis levam esse tipo de informação em conta, fato comprovado pela espontaneidade de ampla divulgação concernente aos itens do CI que aparecem em seus relatórios. 
Este trabalho buscou mostrar a evidenciação do Capital Intelectual por meio das demonstrações contábeis e relatórios financeiros. Trata-se de uma pequena contribuição ao estudo do CI, um item não recente no mundo acadêmico, mas que carece de muita pesquisa, principalmente aquelas que possam desenvolver modelos para sua mensuração, por isso, recomenda-se como extensão deste trabalho o desenvolvimento de modelo para a mensuração do CI não só nas instituições financeiras, mas também em outros segmentos.

Assim, faz-se necessária a continuação da pesquisa com o intuito de descobrir como a evidenciação do Capital Intelectual pode aumentar o valor da empresa, além da elaboração de um modelo que possa valorar os itens componentes do Capital Intelectual e por último o reconhecimento e desreconhecimento dos itens do Capital Intelectual nas demonstrações contábeis, clássicas, Balanço Patrimonial, Demonstração de Resultado do Exercício e Demonstração dos Fluxos de Caixa. 



\section{REFERÊNCIAS}

ANTUNES, Maria Thereza Pompa. A Controladoria e o Capital Intelectual: um estudo empírico sobre sua gestão. Revista Contabilidade e Finanças. - USP. São Paulo, n. 41, p. 21-37, 05-08/2006.

. O Capital Intelectual segundo o entendimento dos gestores das empresas brasileiras. Revista Brasileira de Gestão de Negócios - FECAP. São Paulo, 09-10/2005.

A influência dos investimentos em capital intelectual no desempenho das empresas: um estudo baseado no entendimento de gestores de grandes empresas brasileiras. São Paulo, 2004. Tese (Doutorado) - Programa de Pós-Graduação em Ciências Contábeis, Departamento de Contabilidade e Atuária, Faculdade de Economia, Administração e Contabilidade da Universidade de São Paulo.

. Capital intelectual. São Paulo: Atlas, 2000.

ASSAF NETO, Alexandre. Mercado financeiro. 4 ed. São Paulo: Atlas, 2001.

BACKES, Rosemary Gelatti. Evidenciação do capital intelectual: análise de conteúdo dos relatórios de administração de companhias abertas brasileiras. São Leopoldo, 2005. Dissertação (Mestrado) - UNISINOS.

BARDIN, Laurence. Análise de conteúdo. 3. ed. Lisboa: edições 70, 2004.

BARTH, Mary E. et al.. Market effects of recognition and disclosure. 2001. Disponível em: <http://papers.ssrn.com/sol3/papers.cfm?abstract_id=245971>. Acesso em: 15/01/2009.

BEKER, Carolina Harumi Koshima. Clima organizacional no contexto de uma organização em processo de pré-fusão: um estudo de caso de uma indústria alimentícia. São Paulo, 2006. Dissertação (Mestrado) - Programa de Pós-Graduação em Ciências Contábeis, Departamento de Contabilidade e Atuária, Faculdade de Economia, Administração e Contabilidade da Universidade de São Paulo.

BOLSA DE MADRID. Bolsas y mercados españoles (BME). Madri, 2008. Disponível em: $<$ http://www.bolsamadrid.es/esp/contenido.asp?enlace=/esp/mercados/acciones/accind1_1.ht m>. Acesso em: 28/06/2008.

BOLSA DE MERCADORIAS E FUTUROS - BOLSA DE VALORES DE SÃO PAULO. Seleção de bancos listados. São Paulo, 2008. Disponível em: <http://www.bovespa.com.br/principal.asp>. Acessado em: 15/06/2008.

BRASIL. Lei n. 6.404/76. Lei das Sociedades por Ações. Presidência da República. Brasília, DF, 1976. 
Lei n. 9.249/95. Lei que altera a Legislação do Imposto de Renda das Pessoas Jurídicas, bem como da Contribuição Social sobre o Lucro Líquido, e dá outras providências. Presidência da República. Brasília, DF, 1995.

Lei n. 11.638/07. Lei das Sociedades por Ações. Presidência da República. Brasília, DF, 2007.

BROOKING, Annie. Intellectual capital: core asset for the third millennium enterprise. Boston : Thomson Publishing, 1996.

CARIOLA. Alfio et al.. Corporate governance, intellectual capital and value creation. SSRN, 2007. Disponível em: <http://ssrn.com/abstract=1011981>. Acesso em: 10/10/2008.

CARVALHO, L. Nelson et al.. Contabilidade internacional. São Paulo: Atlas, 2006.

COLLIS, Jill; HUSSEY, Roger. Pesquisa em administração: um guia prático para alunos de graduação e pós-graduação. 2. ed. Porto Alegre: Bookman, 2005.

COMISSÃO DE VALORES MOBILIÁRIOS. Deliberação CVM n. 488. Rio de Janeiro, 2005. Disponível em: <www.cvm.gov.br/>. Acesso em: 23/11/2008.

Deliberação CVM n. 553. Ativos Intangíveis - Pronunciamento Técnico CPC 04. Rio de Janeiro, 2008. Disponível em: <www.cvm.gov.br/>. Acesso em: 14/01/2009.

Estudo sobre as práticas contábeis brasileiras e as normas internacionais de contabilidade (IFRS) - Estudo elaborado pela Ernst \& Young Brasil, com revisão da Fundação Instituto de Pesquisas Contábeis, Atuariais e Financeiras (FIPECAFI). Rio de Janeiro, 2008. Disponível em: <www.cvm.gov.br/>. Acesso em: 20/02/2009.

CONSELHO FEDERAL DE CONTABILIDADE. Resolução n. 774 - Apêndice à Resolução sobre os Princípios Fundamentais de Contabilidade. Brasília, 1994. Disponível em: $<$ http://www.cfc.org.br/sisweb/sre/detalhes_sre.aspx?Codigo=1994/000774>. Acesso em: 14/09/2008.

COMITÊ DE PRONUNCIAMENTOS CONTÁBEIS. Pronunciamento conceitual básico Estrutura Conceitual. Brasília, 2008. Disponível em: <www.cpc.org.br/>. Acesso em: $15 / 05 / 2008$.

CPC 04 - Ativo Intangível. - Brasília, 2008. Disponível em: <www.cpc.org.br/>. Acesso em: 25/05/2008.

COMISIÓN NACIONAL DEL MERCADO DE VALORES. Modelos normalizados y legislación. Madri, 2008. Disponível em: <http://www.cnmv.es/index_n.htm?/ legislacion/modelos.htm /p_legislacion_3.html>. Acesso em: 06/12/2008. 
CRAWFORD, Richard. Na era do capital humano. São Paulo: Atlas, 1994.

DRUCKER, Peter F. A nova era da administração. São Paulo: Pioneira, 1999.

. Sociedade pós-capitalista. São Paulo: Pioneira, 1994.

Uma era de descontinuidade. Rio de Janeiro: Zahar, 1970.

EDVINSSON, L.; MALONE, M. S. Capital intelectual. São Paulo: Makron Books, 1998.

El-BANNANY, Madgi. A study of determinants of intellectual capital performance in banks: the UK case. Journal of Intellectual Capital, 9(3), p. 487-498, 2008. Disponível em: $<$ EBSCO/ ABI/INFORM Global database. (Document ID: 1538346921)>. Acesso em: $03 / 11 / 2008$.

ERNST \& YOUNG; FIPECAFI. Manual de normas internacionais de contabilidade: IFRS versus Normas Brasileiras. São Paulo: Atlas, 2009.

FERNANDÉZ, Pablo. Valuation of brands and intellectual capital. Madrid: IESE Business School, 2001. Disponível em: <http://ssrn.com/abstract=270688>. Acesso em: 15/10/2008.

FLEURY, Afonso; FLEURY, Maria Tereza Leme. Aprendizagem e inovação organizacional: as experiências de Japão, Coréia e Brasil. 2. ed. São Paulo: Atlas, 1997.

Maria Tereza Leme; OLIVEIRA JUNIOR, Moacir de Almeida. Gestão estratégica do conhecimento: integrando aprendizagem, conhecimento e competências. São Paulo: Atlas, 2001.

FORTUNA, Eduardo. Mercado financeiro: produtos e serviços. Rio de Janeiro: Qualitymark, 2002.

GIL, Antônio Carlos. Como elaborar projetos de pesquisa. 4. ed. São Paulo: Atlas, 2002.

GLOBAL REPORTING INITIAVE. Support for reporters. Amsterdam, 2009. Disponível em: < http://www.globalreporting.org/GRIReports/>. Acesso em: 09/07/2009.

HENDRIKSEN, Eldon S.; VAN BREDA, Michael F. Teoria da Contabilidade. 5. ed. São Paulo: Atlas, 1999.

INTERNATIONAL ACCOUNTING STANDARDS BOARD - IAS. Proposed amendments to IAS 39 and IFRS 7. 2008. Disponível em: <http://www.iasb.org/Current+Projects/ IASB+Projects/Derecognition/Derecognition.htm>. Acesso em: 16/04/2009. 
International Financial Reporting Standards (IFRSs) 2008. London: IASCF, 2008. Framework.

. International Financial Reporting Standards (IFRSs) 2008. London: IASCF, 2008. - IFRS 3.

International Financial Reporting Standards (IFRSs) 2008. London: IASCF, 2008. - IAS 16.

International Financial Reporting Standards (IFRSs) 2008. London: IASCF, 2008. - IAS 36.

International Financial Reporting Standards (IFRSs) 2008. London: IASCF, 2008. - IAS 38.

IUDÍCIBUS, Sérgio de. Teoria da contabilidade. 8. ed. São Paulo: Atlas, 2006.

et al. Manual de contabilidade das sociedades por ações: aplicável as demais sociedades. 7. ed. São Paulo: Atlas, 2007.

. Manual de contabilidade das sociedades por ações: Suplemento. São Paulo: Atlas, 2008.

KOEPSELL, David R. The mystery of intellectual capital: a prospectus. University of Buffalo, SSRN, 2006. Disponível em: <http://ssrn.com/abstract=1127660>. Acesso em: $12 / 10 / 2008$.

LEV, Baruch. Intangibles: management, measurement, and reporting. Washington: Brookings Institution Press, 2001.

LIMA, Iran Siqueira et al. (Org.) Curso de mercado financeiro: tópicos especiais. São Paulo: Atlas, 2007.

LOPES, Alexsandro Broedel; MARTINS, Eliseu. Teoria da contabilidade: uma nova abordagem. São Paulo: Atlas, 2005.

The relation between firm-specific corporate governance, cross-listing and the informativeness of accounting numbers in Brazil. Manchester, $2008 \mathrm{PhD}$ (Thesis) -. Manchester Business School, United Kingdom.

; ALENCAR, Roberta Carvalho de. Disclosure and cost of equity capital in emerging markets: the Brazilian case. 2008. Disponível em: <http://papers.ssrn.com/sol3/ papers.cfm?abstract_id=1099900>. Acesso em: 24/03/2009. 
MARTINS, Eliseu. Contribuição a avaliação do ativo intangível. São Paulo, 1972. Tese (Doutorado) - Faculdade de Economia, Administração e Contabilidade da Universidade de São Paulo.

_, Gilberto de Andrade. Manual para elaboração de monografias e dissertações. 3. ed. São Paulo: Atlas, 2002.

; THEÓPHILO, Carlos Renato. Metodologia na investigação científica para ciências sociais aplicadas. São Paulo: Atlas, 2007.

MAYER, Thomas; DUESENBERRY, James S. Moeda, bancos e a economia. Rio de Janeiro: Campus, 1993.

MISHKIN, Frederic S. Moedas, bancos e mercados financeiros. 5. ed. Rio de Janeiro: LTC, 2000.

MONOBE, Massanori. Contribuição a mensuração e contabilização do goodwill não adquirido. São Paulo, 1986. Tese (Doutorado) - Faculdade de Economia, Administração e Contabilidade da Universidade de São Paulo.

MOURITSEN, J. H. Thorgsgaard; BUKH, P. N. Dealing with the knowledge economy: intellectual capital versus balanced scorecard. Copenhagen: Copenhagen Business School, 2002.

NAKAGAWA, Masayuki. Introdução à controladoria: conceitos, sistemas, implementação São Paulo: Atlas, 1993.

NIYAMA, Jorge Katsumi. Contabilidade internacional. São Paulo: Atlas, 2005.

NONAKA, Ikujiro; TAKEUCHI, Hirotaka. Criação de conhecimento na empresa. Rio de Janeiro: Campus, 1997.

NOSSA, Valcemiro. Disclosure ambiental: Uma análise do conteúdo dos relatórios ambientais de empresas no setor de papel e celulose em nível internacional. São Paulo, 2002. Tese (Doutorado) - Programa de Pós-Graduação em Ciências Contábeis, Departamento de Contabilidade e Atuária, Faculdade de Economia, Administração e Contabilidade da Universidade de São Paulo.

OLIVEIRA, Antonio Benedito Silva et al. Métodos e técnicas de pesquisa em contabilidade. São Paulo: Saraiva, 2003.

OLIVEIRAS, Ester; KASPERKAYA, Yulia. Reporting intellectual capital in Spain, 2004. UPF Economics and Business Working Paper 781. Disponível em: $<$ http://ssrn.com/abstract=848664>. Acesso em: 12/10/2008. 
PACHECO, Vicente. Mensuração e divulgação do capital intelectual nas demonstrações contábeis: teoria e empiria. Curitiba: Conselho Federal de Contabilidade do Paraná, 2005.

QUINN, J. B. Intelligent enterprise. New York: The Free Press, 1992.

RICCIO, Edson Luiz. Uma contribuição ao estudo da contabilidade como sistema de informação. São Paulo, 1989. Tese (Doutorado) - Programa de Pós-Graduação em Ciências Contábeis, Departamento de Contabilidade e Atuária, Faculdade de Economia, Administração e Contabilidade da Universidade de São Paulo.

Efeitos da tecnologia de informação na contabilidade - estudo de casos de implementação de sistemas empresariais integrados. São Paulo, 2001. Tese (Livre-Docência) - Faculdade de Economia, Administração e Contabilidade da Universidade de São Paulo.

SALVADOR, Ângelo Domingos frei. Métodos e técnicas de pesquisa bibliográfica, elaboração e relatório de estudos científicos. Porto Alegre: Sulina, 1980.

SAMMARTINO, Wagner. A integração do sistema de gestão de recursos humanos com as estratégias organizacionais. São Paulo, 2002. Tese (Doutorado) - Programa de PósGraduação em Administração, Departamento de Administração, Faculdade de Economia, Administração e Contabilidade da Universidade de São Paulo.

SANTIAGO JÚNIOR, José Renato Sátiro; SANTIAGO, José Renato Sátiro. Capital intelectual: o grande desafio das organizações. São Paulo: Novatec, 2007.

SILVA, Antonio Carlos Ribeiro de. Metodologia da pesquisa aplicada à contabilidade: orientações de estudos, projetos, relatórios, monografias, dissertações teses. São Paulo: Atlas, 2003.

STEWART, Thomas A. The wealth of knowledge: intellectual capital and the twenty-first century. New York: Currency Books, 2001.

SVEIBY, Karl Erik. The new organizational wealth: managing and measuring knowledgebased assets. San Francisco: Berrett-Koehler Publishers, 1997. 


\section{APÊNDICES}

Apêndice 1 - Capital Intelectual: Brasil 1S08 Apêndice 2 - Capital Intelectual: Brasil 2007 Apêndice 3 - Capital Intelectual: Brasil 2006 Apêndice 4 - Capital Intelectual: Espanha 1S08 Apêndice 5 - Capital Intelectual: Espanha 2007 Apêndice 6 - Capital Intelectual: Espanha 2006 
APÊNDICE 1 - CAPITAL INTELECTUAL: BRASIL $1 S 08$

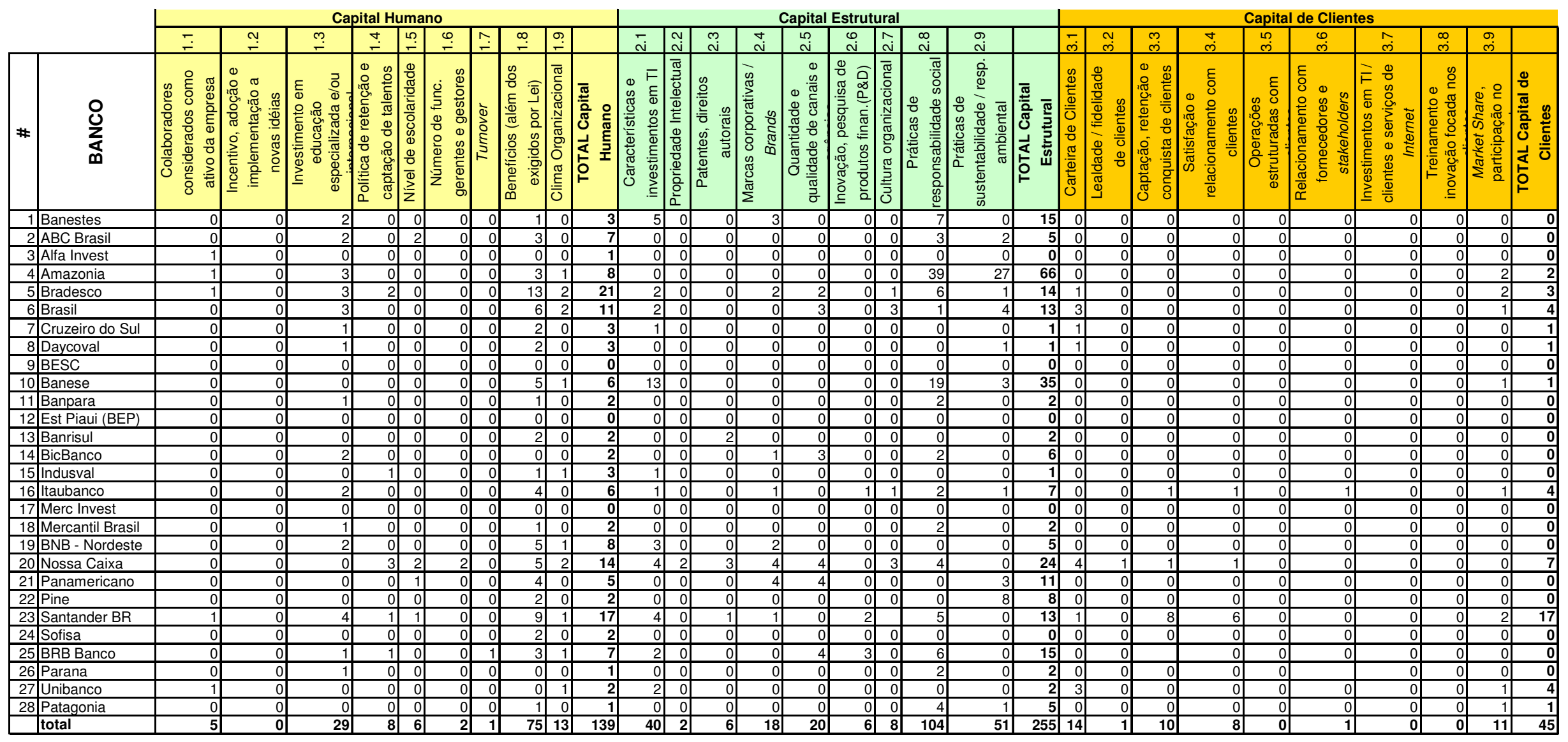



APÊNDICE 2 - CAPITAL INTELECTUAL: BRASIL 2007

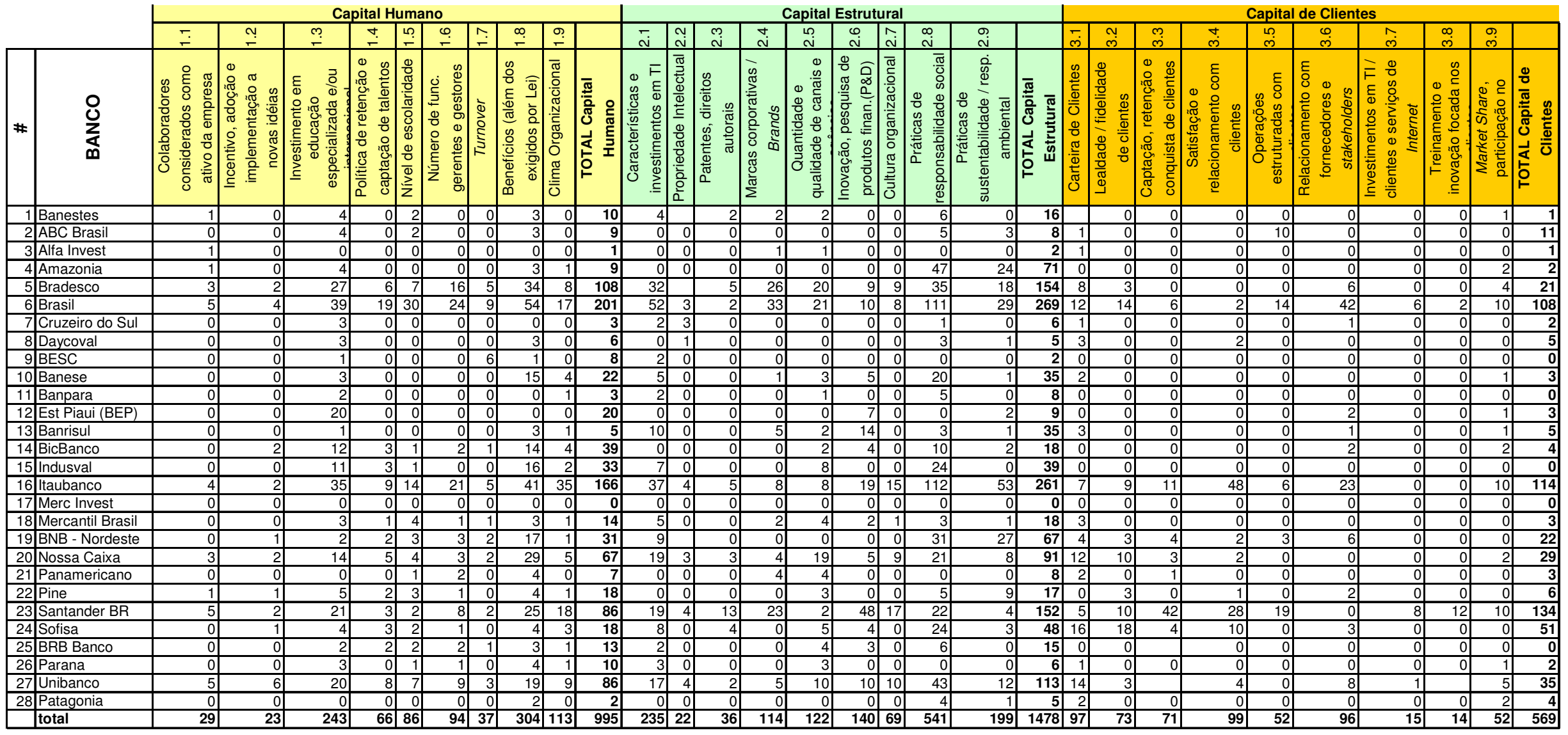



APÊNDICE 3 - CAPITAL INTELECTUAL: BRASIL 2006

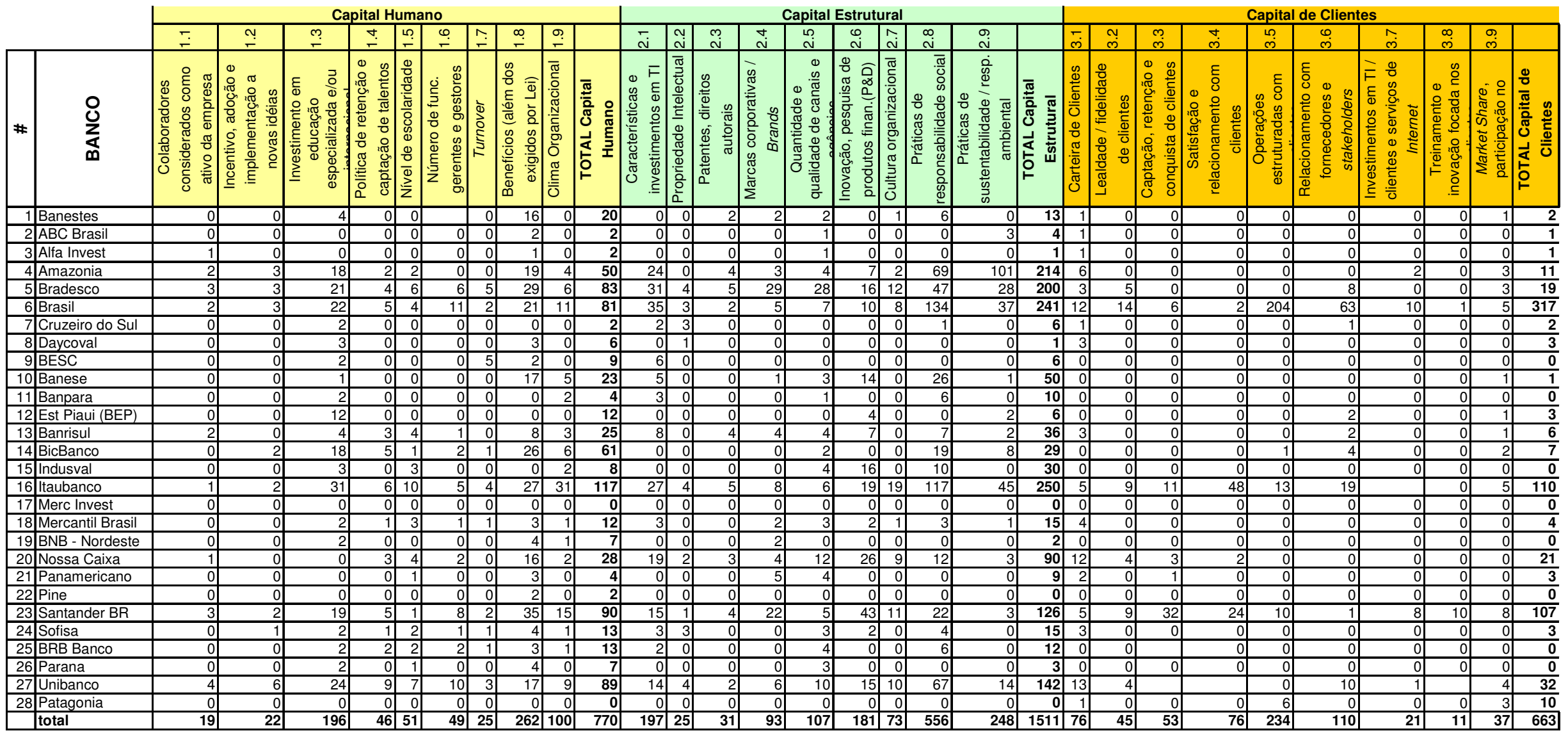



APÊNDICE 4 - CAPITAL INTELECTUAL: ESPANHA $1 S 08$

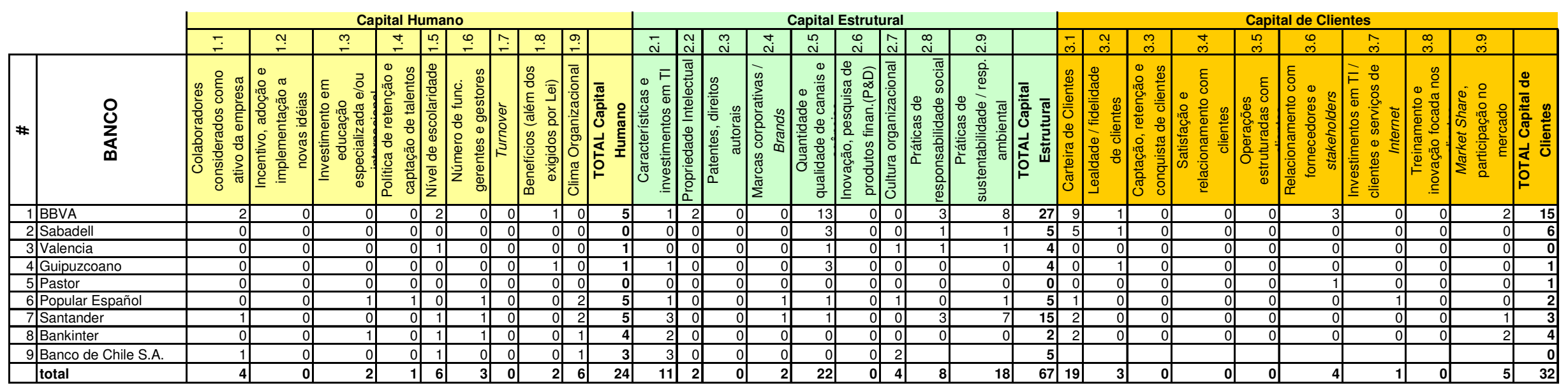



APÊNDICE 5 - CAPITAL INTELECTUAL: ESPANHA 2007

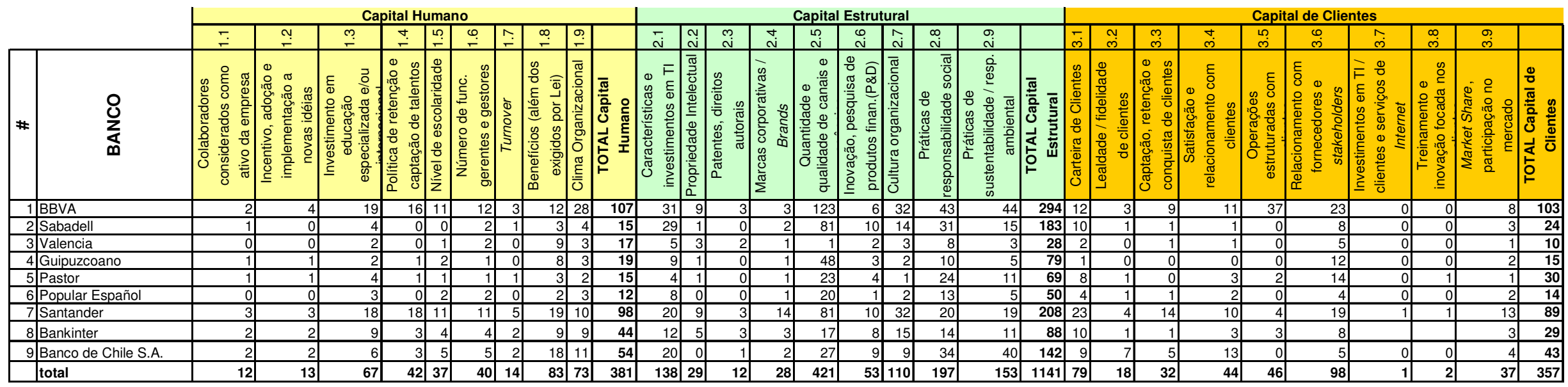



APÊNDICE 6 - CAPITAL INTELECTUAL: ESPANHA 2006

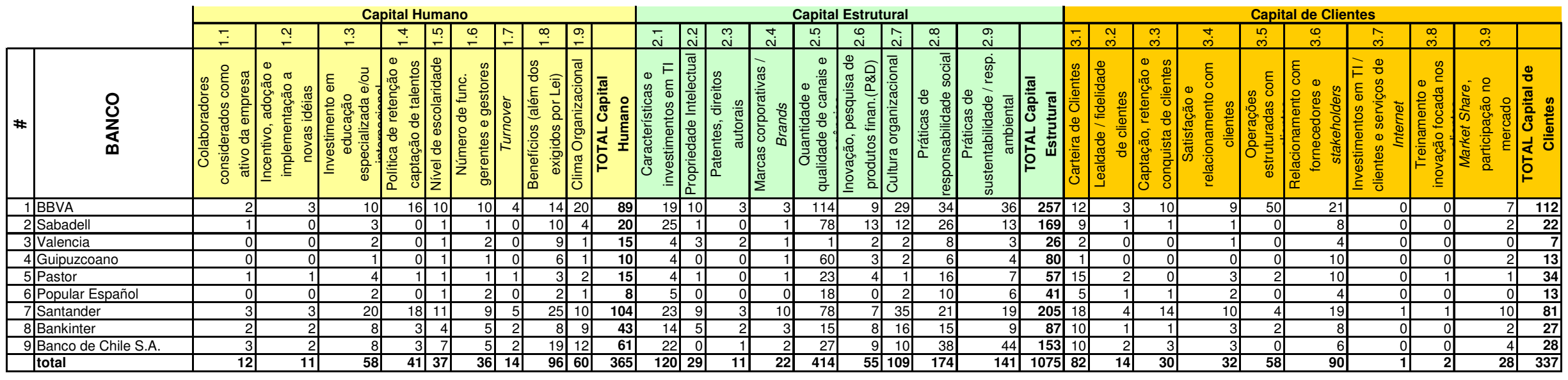

